Portland State University

PDXScholar

Fall 12-13-2013

\title{
Who Owns This Body? Enslaved Women's Claim on Themselves
}

Loucynda Elayne Sandeen

Portland State University

Follow this and additional works at: https://pdxscholar.library.pdx.edu/open_access_etds

Part of the United States History Commons, and the Women's History Commons Let us know how access to this document benefits you.

Recommended Citation

Sandeen, Loucynda Elayne, "Who Owns This Body? Enslaved Women's Claim on Themselves" (2013). Dissertations and Theses. Paper 1492.

https://doi.org/10.15760/etd.1491

This Thesis is brought to you for free and open access. It has been accepted for inclusion in Dissertations and Theses by an authorized administrator of PDXScholar. Please contact us if we can make this document more accessible: pdxscholar@pdx.edu. 


\title{
Who Owns This Body?: \\ Enslaved Women's Claim On Themselves
}

\author{
by
}

Loucynda Elayne Sandeen

A thesis submitted in partial fulfillment of the requirements for the degree of

\author{
Master of Arts \\ in \\ History
}

Thesis committee:

Patricia Schechter, Chair

Shawn Smallman

Tim Garrison

Sue Peabody

Portland State University

2013 
(C) 2013 Loucynda Elayne Sandeen 


\begin{abstract}
During the antebellum period of U.S. slavery (1830-1861), many people claimed ownership of the enslaved woman's body, both legally and figuratively. The assumption that they were merely property, however, belies the unstable, shifting truths about bodily ownership. This thesis inquires into the gendered specifics and ambiguities of the law, the body, and women under slavery. By examining the particular bodily regulation and exploitation of enslaved women, especially around their reproductive labor, I suggest that new operations of oppression and also of resistance come into focus.

The legal structure recognized enslaved women in the interest of owners, and this limitation was defining, meaning that justice flowed in one direction. If married white women were "civilly dead," as famously evoked by the Declaration of Sentiments (1848) then enslaved women were civilly non-existent. The law controlled, but did not protect slaves, and a number of opponents to slavery denounced this contradictory scenario during the antebellum era (and before). Literally, enslaved women were claimed by their masters, purchased and sold as chattel. Physically, they were claimed by those men (both white and black) who sought to have power over them. Symbolically, they were claimed by anti-slavers and pro-slavers alike when it suited their purposes, often in the domains of news and literature, for the sake of advancing their ideas, a rich record of which fills court cases, newsprint, and propaganda touching the slavery issue before the civil war.

Due to the numerous ways that enslaved women's bodies have been claimed, owned, or circulated in markets, it may have been considered implicit to many that others owned their bodies. I believe that this is an oversimplified historical supposition that needs to be re-theorized. Indeed, enslaved women lived in a time when they were often
\end{abstract}


led to believe that their bodies were not truly their own, and yet, many of them resisted their particular forms of oppression by claiming ownership of their bodies and those of their children; sometimes using rather extreme methods to keep from contributing to their oppression. In other words, slave owners' monopoly of the legal, economic, and logistical meanings of ownership of slaves had to be constantly reaffirmed and negotiated. This thesis asks: who owned the enslaved woman's body? I seek to emphasize that enslaved women were valid claimants of themselves as can seen in primary sources that today have only been given limited expression in the historiography. 
For my best friend and husband, Jake,

who understood why I had to do this project and supported me every step of the way. There could be no better partner for my life.

For my daughter, Elayna Grace, who is my constant light and my reason for everything. 


\section{Acknowledgements}

This work would not have been possible without the continued support of many people in my life. I am extremely grateful to each and every one of them.

First and foremost, I would like to thank my amazing adviser and mentor, Professor Patricia Schechter, who saw potential in me-a young undergraduate student who would not otherwise have deemed myself capable of even becoming a graduate student- and who dedicated long hours to helping me apply for, work toward, and complete my M.A. in History, even when life created a long detour from this path. I can not express my gratitude for her guidance and patience. She is a strong female role model in my life and I credit her for some of my confidence and strength, both inside and outside of academia.

I would also like to thank my family, who have all believed in me and continued to cheer me on.. They all knew I was capable of this, even when I wasn't as sure, and that faith helped to push me through. To my mother, Syndee Jensen, my step-father Bill McKeeman, and to my in-laws, Jackie and Steve Sandeen, you have all been with me on this journey in your own ways and I am immensely grateful for your continued love and support. You made me feel as though you never had a doubt, and it is partly the desire to make you proud that has helped me persist. I feel very blessed to have you all in my life.

To my amazing husband, Jake Sandeen. I sometimes wonder how you had the patience to watch me in every step of this process - to listen to my endless thoughts on this paper, to allow the stacks of books (and papers and binders and folders and sticky notes) to cover our office shelves, desk, and floor, to smile and nod when I told you that I 
would finish this someday, but I am SO very grateful that you did. Our entire relationship has unfolded while I was conceptualizing, researching, reading, writing, revising, and evolving this project, and you were my biggest supporter through it all. THANK YOU for being the incredible partner that you are, and for always believing I could do this.

Finally, to my little girl, Elayna. I will admit that it was not easy to sacrifice time with you to sit down and finish this thesis. In fact, my life with you is so important to me that it could be the reason I put off finishing for a while. Yet, without even knowing, you gave me the final reason I needed to complete this project. I looked at you and realized that I want you to grow up knowing how important you are to me, but also how important education is. Being a student has truly been one of my greatest joys in life. I felt like I had to finish this so you would see that we can do hard things. Hopefully you will live your life in a way that allows for some big challenges and sacrifices. They will only make you stronger.

To everyone else who has contributed time and energy to this project—professors who have taken the time inspire me and to help me grow as a historian, friends who have helped me by offering their time and ears, and other friends and family who have been sure to let me know that they believed in me, thank you all. I truly couldn't have done this alone. 


\section{Table of Contents}

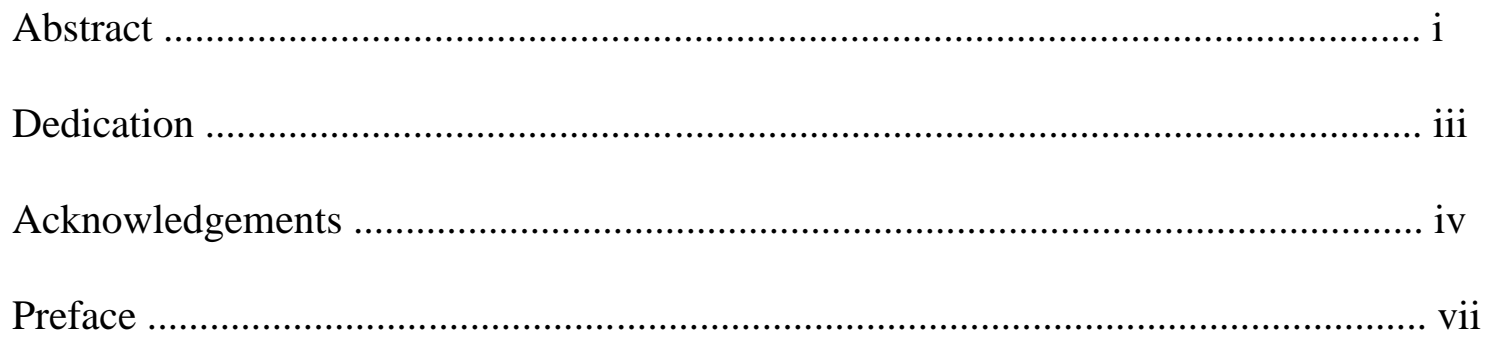

\section{Chapter 1}

"The Power To Name One's Own Reality": Theory and Method in the Study of Ownership of the Enslaved Woman's Body ............................................................. 1

\section{Chapter 2}

"Regulations of Robbers": Legalized Rape of Enslaved Southern Women in

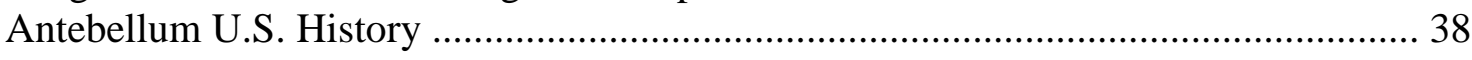

\section{Chapter 3}

When They Claimed Themselves: Bondswomen's Resistance \& Self-Ownership Through Reproductive Choice........................................................................ 74

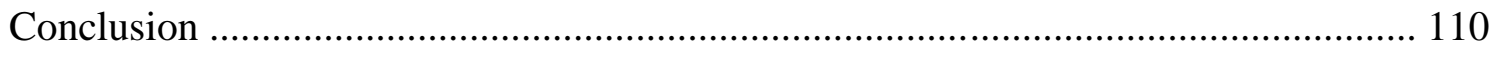

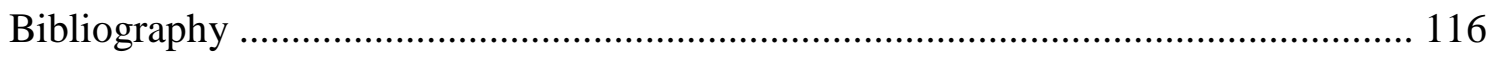




\section{Preface}

As a young college student, I found myself consistently drawn to the history of slavery and to women's history. I remember focusing in on the bits and pieces about slave women when listening to lecture on U.S. history, and wondering exactly how they really fit. I remember thinking that it seemed odd that they were so central to the system and yet practically missing from the general history texts. I tried to imagine their lives and could not. When a professor of mine recognized my interests and recommended I read Deborah Gray White's book, Ar'n't I a Woman it seems that my ideation began. I read it eagerly, and when I finished, I read it again. The next summer I was given a research grant, and I chose to focus on resistance to slavery through reproductive choice. I felt like it had only been marginally discussed in the historiography and wanted to understand why. As a master's student, I knew I wanted to focus my research on enslaved women's experiences and their agency and resistance, but when my adviser asked me why, I told her that it was because I wanted to ask who owned their bodies? After all I had read and the work I had already begun, I finally knew I wanted to talk about the ways that others claimed them, but that it was important because it helped me to explain how they claimed themselves.

While doing the deep, rooting search through the scraps of documentation left behind from the long and complex history of women and slavery in the U.S. for this thesis, I became aware of the layers and the ambiguities, the missing pieces and the soulsmudging stories, the forgotten voices and the legal trappings in what is commonly referred to as "the" historical record.

Bondswomen occupied a shifting and convoluted place in antebellum societytheir bodies at once made spectacle and commodified, and simultaneously legally 
disempowered—and this complex history is mostly documented in unobvious and fragmented ways. The record is so sparse and multi-genre that I found that historiography and theory were to be crucial friends to me in the writing of this thesis, and they remain front and center in my work. They help to guide how I interpreted the myriad scraps of primary source material that is left as evidence for the lives of enslaved women.

Using what evidentiary material is available, which is not always conspicuous, this thesis seeks to enrich the discussion about enslaved women's history, their bodies and the laws that governed them, those who tried to own them, and the choices that they made in situations of choicelessness - the ways they laid claim to themselves. In a system perpetuated through rape and slave breeding, sometimes these choices took the form of resistance through extreme reproductive choices, like abortion or infanticide.

What is fundamental to discern is that the only thing that rape, or breeding, or infanticide means is what the historical actors and we in the present time say it means, and there is little agreement in either domain. These shifting definitions then create a space where we can continue the conversation, and the conversation between the past and present is the key for scholarly process of historical narration.

The history of the enslaved woman's body is still important to the current political and social dialogue. We see its salience today in the recent wave of interest surrounding the uncovering of First Lady Michelle Obama's ancestral history, its direct connection to slavery, and the likely sexual exploitation of her enslaved great-great-great-grandmother Melvinia (who was impregnated by a white man while still in her early teens). Michelle Obama's family legacy, however fragmented, has now become a live part of the 
discussions surrounding her modern identity and due to her status as the first Lady, of American identity. ${ }^{1}$

The modern discipline of history privileges the written record, especially those produced in official settings with the sanction and approval of established authoritieschurch, state, and court. The history of slavery, as part of the history of empire and trade, is quite well documented in this traditional sense. Some aspects of slavery though, the daily side, the domains of the family and intimacy, are more challenging to seek in written documentation. Much of this is in private hands, like diaries, letters, and plantation accounts. Still other domains — the press, evangelical literature, and political pamphleteering tend to capture the activist voices focused for and against slavery. The domain of oral history is yet another genre of materials, mediated in its own way through the interview and transcription process in the Works Progress Administration and elsewhere. In a history that is filled with bills of sale, court reports missing bondswomen's voices (even when matters concerning their most intimate selves were on trial), and plantation journals that logged the purchase of human beings, this thesis seeks to carve out a more inclusive definition of ownership of bondswomen's bodies. I read broadly across genres, aware that silences can speak volumes. With the weight of the words and the silences and the resonance in between, I argue that enslaved women claimed their bodies in ways previously ignored, in a social reality that strongly asserted that they had no right to do so.

\footnotetext{
${ }^{1}$ Rachel L. Swarns, American Tapestry: The Story of the Black, White, and Multiracial Ancestors of Michelle Obama (New York: Harper Collins Publishers, 2012); Mary C. Curtis, "Why Michelle Obama's Very American Story Still Causes a Stir," The Washington Post, July 12, 2012. 


\section{Chapter 1}

"The Power To Name One's Own Reality"':

Theory and Method in the Study of Ownership of the Enslaved Women's Body

It seemed not only hard, but unjust, to pay for myself. I could not possibly regard myself as a piece of property. [...] I knew the law would decide that I was his property, [...]but I regarded such laws as the regulations of robbers, who had no rights that I was bound to respect.

Harriet A. Jacobs $(1857)^{3}$

Harriet Jacobs's remarks above, from her much-cited narrative Incidents in the Life of a Slave Girl (published in 1861), distinguishes between the law of antebellum America and her own moral code regarding the ownership of her body, rejecting strongly the former in favor of the latter. The reference "no rights I was bound to respect" specifically marks Jacobs's understanding and fluency with the Supreme Court decision Dred Scott v. Sanford (1857) which, among other things, clearly made individuals categorized as "free Negro" essentially stateless persons, without citizenship and with "no rights a white man" was "bound to respect," as Justice Taney put it. ${ }^{4}$ This speaking back

\footnotetext{
${ }^{2}$ Patricia Hill Collins Black Feminist Thought: Knowledge, Consciousness, and the Politics of Empowerment (New York: Routledge Press, 2008), 114. This except from Patricia Hill Collins underscores the import that I place on the concept of "self-definition" in enslaved women's resistance to slavery and the claims that they made on their own bodies, when others wanted (and want) to claim them.

${ }^{3}$ Harriet A. Jacobs, Incidents in the Life of a Slave Girl: Written By Herself. Edited by Jean Fagan Yellin. (Cambridge: Harvard University Press, 1987), 187. Jacobs was well aware that she was regarded as property. She includes in her narrative a copy of the "Deathbed Codicil" by Margaret Horniblow (dated July 3,1825 ) which includes the things she left to her 3-year-old niece Matilda Norcom. Among the items are a work table and contents, bureau, and one "negro girl Harriet." Jacobs, Incidents in the Life of a Slave Girl, 213.

${ }^{4}$ Dred Scott v. Sandford, 60 U.S. 393 (1857) as quoted in A. Leon Higginbotham, Jr., "Racism and the Early American Legal Process, 1619-1896," Annals of the American Academy of Political and Social Science, Vol. 407 (May 1973), 1. Slaves also had no rights a white man was bound to respect, but for different reasons. They were more of a contradiction and not considered as persons under the law-instead being subject to property laws.
} 
to power is eloquent and emphatic in Jacobs's book, and this thesis seeks out similar gestures, not always captured in words, in which enslaved women acted on their own estimation of their rights in critique of, and resistance to, the coercive powers arrayed around them.

Jacobs's book contains much evidence about how she, and many people in her family and surrounding community, claimed ownership of their bodies, both legally and figuratively, in myriad ways during the antebellum period of slavery (1830-1861). In particular, Jacobs is interested in the gender burdens inherent to enslavement. "Slavery is terrible for men; but it is far more terrible for women," she wrote, "Superadded to the burden common to all, they have wrongs, and sufferings, and mortifications peculiarly their own." ${ }^{5}$ For all slaves, the assumption that they were merely property belies the grayer truths about bodily ownership, but Jacobs points us to the gendered particulars. Within this ideation of the body as owned we contend with a multitude of ambiguous, unstable concepts and definitions. Historians, especially black feminist historians, have addressed the issues of grayer, ambiguous spaces with an urgency directly related to Jacobs's. Namely, the need to recover and recuperate authority over their bodies and stories about their bodies, which served some significant cultural purposes of legitimation and identity construction. Recognizing this we are left then to ask the more complex questions. Who really owned the bodies of enslaved women? How do we, as historians, define ownership? Is it a simple matter of claim, something recognized legally, or something much more convoluted? As historian Martha Hodes so simply stated, "all

\footnotetext{
${ }^{5}$ Jacobs, Incidents in the Life of a Slave Girl, 77.
} 
answers to questions about societies that operated under human bondage include paradoxes." 6

This thesis inquires into the gendered specifics and ambiguities of the law, the body, and women under slavery. Building on recent scholarship by Stephanie Camp, Dorothy Roberts, and Jennifer Morgan, all of whom highlight enslaved women's distinct methods of agency and resistance, I suggest that by examining the particular bodily regulation and exploitation of slave women, especially around their reproductive labor, new operations of oppression and resistance come into focus. ${ }^{7}$ This allows historians to make advantageous connections between slavery and other formations of power, like colonialism, so endemic to the antebellum decades, but often left to the side of studying racialized power and identity under slavery.

Especially key is Ann Stoler's concept of the "intimate" as a deeply gendered site of control and resistance-essentially the domain in which race was produced and reproduced through familial, medical, and sexual activities-helps put Jacobs's retheorizations of morality and the law into fresh perspective. As Stoler points out, the intimate does not inhabit the fringe of the social, but instead is a central if sometimes obscured site of embattled space. These spaces can be physical, social, geographic, even architectural; each can be fought for and protected, manipulated, and control sought over. The innermost spaces (which include, but are not limited to, the physical and sexual

\footnotetext{
${ }^{6}$ Martha Hodes, White Women, Black Men: Illicit Sex in the Nineteenth-Century South (New Haven: Yale University Press, 1997), 6.

${ }^{7}$ Stephanie M. H. Camp, Closer to Freedom: Enslaved Women and Everyday Resistance in the Plantation South (Chapel Hill: University of North Carolina Press, 2004); Jennifer L. Morgan, Laboring Women: Reproduction and Gender in New World Slavery (Philadelphia: University of Pennsylvania Press, 2004); Dorothy Roberts, Killing the Black Body; Race Reproduction, and the Meaning of Liberty (New York: Pantheon Books, 1997); See also Sharon Block, Rape and Sexual Power in Early America (Chapel Hill: University of North Carolina, 2006).
} 
sphere) are those that hold import as private mental spaces and interior physical spaces, and they are also "privileged sites for the implementation of colonizing techniques of surveillance and control." ${ }^{8}$ The intimate, and along with it ownership of the enslaved woman's body as a central exemplar, then becomes quite imperative as a site of dominance and control. This was certainly the case in antebellum slavery.

Legally, enslaved women were controlled under the law even when they were not protected by it. Literally, they were claimed by their masters, and purchased and sold as chattel. Physically, they were claimed by those men (both white and black) who sought to have power over them; at times even beaten and raped in order to enforce the law of slavery on their persons. Symbolically, they were claimed by anti-slavers and pro-slavers alike when it suited their purposes, often in the domains of news and literature, for the sake of advancing their ideas. Due to the numerous ways that we recognize enslaved women's bodies as having been claimed, or even colonized, it has historically been implicit that others owned their bodies. I believe that this is an oversimplified historical supposition that needs to be re-theorized. Indeed, enslaved women lived in a time when they were often led to believe that their bodies were not truly their own, and yet, many of them resisted their particular forms of oppression by claiming ownership of their bodies and those of their children; sometimes using rather extreme methods to keep from contributing to their race's oppression. So again I ask, who owned the enslaved woman's body? How are such claims made and enforced historically? When and how did such claims stick or fall apart? What conditions permitted power to tip in a particular

\footnotetext{
${ }^{8}$ Ann Laura Stoler, Carnal Knowledge and Imperial Power: Race and the Intimate in Colonial Rule (Berkeley: University of California Press, 2002), Preface; See also Ann Laura Stoler, ed, Haunted By Empire: Geographies of Intimacy in North American History (Durham: Duke University Press, 2006).
} 
direction? Following the concept that they could be claimed, this thesis emphasizes that enslaved women were as important claimants of their bodies as were others around them, in spite of the society that they survived in. Therefore, to say that enslaved women were simply "owned" by "others" seems another opaque extension of the domination that they experienced intimately under slavery. More historical weight should be placed on their claim of themselves. When historians expand the narrative of slavery to highlight contests over power, particularly in the domain of the intimate, space is opened up to contest what sociologist and black feminist theorist Pat Hill Collins calls "controlling stereotypes." Stereotypes all too debilitating still in many modern situations, as the stories of women like Anita Hill, Sally Hemings, or Michelle Obama reflect. ${ }^{9}$

The concept of "ownership" can be usefully unpacked and re-defined in a more dynamic way. Ownership is not absolute, but if we want to recognize anyone as an owner of the enslaved woman's body we must validate the claims that they made on themselves. The evidence in the written, though fragmented and indirect, provides us some clues as to both approach and argument. Slave narratives like that of Harriet Jacobs express enslaved women's subjugated, and yet sometimes oppositional, knowledge of their self-ownership, and their agency with regard to retaining some modicum of control over details of their lives makes it impossible for me to consciously ignore their claim to their bodies. ${ }^{10}$

\footnotetext{
${ }^{9}$ Swarns, American Tapestry; Nell Irvin Painter, "Hill, Thomas, and the Use of Racial Stereotype," in Race-ing Justice En-gendering Power: Essays on Anita Hill, Clarence Thomas, and the Construction of Social Reality, edited by Toni Morrison (New York: Pantheon Books, 1992), 200-214; Annette GordonReed, Thomas Jefferson and Sally Hemings: An American Controversy (Charlottesville: University of Virginia Press, 1997); Peter Nicolaisen, "Thomas Jefferson, Sally Hemings, and the Question of Race: An Ongoing Debate," Journal of American Studies, Vol. 37, No. 1 (2003), 99-118.

${ }^{10}$ Collins, Black Feminist Thought, 301. Collins coined these terms. She says that subjugated knowledges are secret knowledges that are generated by oppressed groups, while oppositional knowledges are those subjugated knowledges that aim to resist this oppression. See also Jacobs, Incidents in the Life of a Slave Girl.
} 
Sojourner Truth certainly demonstrates this process publicly when she deconstructs the concept of the term "woman" in her well known Akron, Ohio speech ("Ain't I a Woman?"), "exposing a concept as ideological or culturally constructed rather than as natural or a simple reflection of reality. ${ }^{11}$ She proudly claimed her body as a woman, a mother, and a laborer, and she seemed strongly opposed to the idea that anyone else would have thought they had the right to categorize her, let alone claim her. ${ }^{12}$

The epigraph by Harriet Jacobs suggests that a person's body can not be truly owned. Ownership is a legal or transacted fiction. Rather, humanity as a rule could be said to submit to the state or governing body in exchange for rights and protections (of which, enslaved women often didn't benefit). Enslaved women had no legal access to marriage, no voice within the law or the courtroom, and no legal protection from anyone when it came to rape. They were essentially unrapeable in legal discourse, but physically and paradoxically they were left available for rape. ${ }^{13}$

For enslaved women, the legally supported oppression of their bodies, and the resistance that they answered with took place in uniquely intimate ways. Rape and the threat of rape is a distinctively personal method of domination that enslaved women experienced, which took place with a physical claiming of their intimate bodies. As alluded to previously, in antebellum legal history we actually find that a slave was not officially rapeable. While this may sound absurd, it was explicitly stated by Mississippi Supreme Court Judge Harris in the 1859 rape case George v. State that "there is no act

\footnotetext{
${ }^{11}$ Collins, Black Feminist Thought, 14-15; See also Nell Irvin Painter, "Representing Truth: Sojourner Truth's Knowing and Becoming Known," Journal of American History, Vol. 81, No. 2 (September 1994), 461-492.

${ }^{12}$ Sojourner Truth, "Ain't I a Woman," (Women's Convention, Akron, Ohio, 1851).

${ }^{13}$ A. Leon Higginbotham, Jr. and Barbara K. Kopytoff, "Racial Purity and Interracial Sex in the Law of Colonial and Antebellum Virginia," Georgetown Law Journal, Vol. 77 (August 1989), 2011-2019.
} 
which embraces either the attempted or actual commission of a rape by a slave on a female slave." ${ }^{14}$ In fact, there was no recognition of a situation involving an enslaved woman that would be considered rape at all. As expressed in law, white masters could do as they wished with the bodies of the women they owned, without legal repercussions. If a man who was not their owner were to molest the body of an enslaved woman, and their master had concern with it, the law viewed it as trespassing on another man's property. ${ }^{15}$ As recent scholarship suggests, the domain of the intimate as a site of power, control, and government legitimacy connects slavery to other modes of domination, like colonialism, in which white sexual domination of women was central. Many historians have held that rape and sexual brutality are acts fundamentally present in the history of expansionism, colonialism, and war, and that they serve a political purpose as acts of domination and power over the group perpetrated upon. ${ }^{16}$ As Antonia Castañeda argues, this method of control is employed as a result of its basic ability to become "a form of national terrorism, subjugation, and humiliation, wherein the sexual violation of women represents both the physical domination of women and the symbolic castration of the men of the conquered group." ${ }^{17}$ This line of thinking directly relates to the history of slavery in U.S. antebellum history, as the elemental tenets behind the history of enslaved women's forced physical coercion were the same. Rape and sexual control were central

\footnotetext{
${ }^{14}$ George v. State, 37 Miss. 316 (1859), 320; See also Peter W. Bardaglio, "Rape and the Law in the Old South: Calculated to Excite Indignation in Every Heart." The Journal of Southern History, Vol. 60 (November 1994), 758-9; See also Diane Miller Sommerville, Rape and Race in the Nineteenth-Century South (Chapel Hill: University of North Carolina Press, 2004), 65.

${ }^{15}$ Jacobs, Incidents in the Life of a Slave Girl, 265.

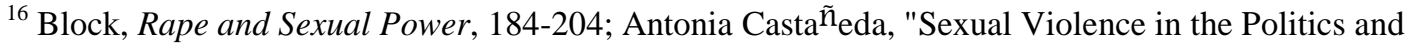
Policies of Conquest: Amerindian Women and the Spanish Conquest of Alta California." In Building With Our Hands: New Directions in Chicana Studies, edited by Adela de la Torre and Beatríz M. Pesquera (Berkeley: University of California Press, 1993), 15-33; See also Gerda Lerner, The Creation of Patriarchy (New York: Oxford University Press, 1986).

${ }^{17}$ Casta $\tilde{n}_{\text {eda, }}$ "Sexual Violence in the Politics and Policies of Conquest," 25.
} 
methods of domination in times of slavery, and these acts certainly affected more than the women themselves, contributing to the power that slaveholders held over their slaves and the tenuous hold that white men had over black. Controlling enslaved women meant effectively controlling their children as well (due to partus sequitur ventrem), and this left enslaved men without power over those that they loved and often times considered family. Without that power, enslaved men, too, were rendered outwardly ineffective. Also connecting slave rape to this ideology of power through sexual brutality during colonialism is the fact that part of its appeal in colonialism was that rape was defined as a crime against property (and in this same vein against territory). ${ }^{18}$ During slavery enslaved women were granted the legal protection of chattel, regulating their place as property to be claimed. It becomes evident that certain ambiguities and myriad definitions become interconnected and complicated when discussing the import and manipulation of sexual coercion in slavery and in the method of colonizing enslaved women's bodies. Stoler asserts that sexuality under colonialism has multi-layered significance-_"symbolically rich and socially salient at the same time. But sexual control was more than a convenient metaphor for colonial domination." ${ }^{19}$ It was also an integral class and racial marker at play in a much broader regime of power.

Still, as the Old South's legal system failed to extend protection to enslaved women, essentially enabling their rape, and as they survived often times in a system of breeding that they were ultimately expected to perpetuate regardless of the power that

\footnotetext{
${ }^{18}$ Ibid.

${ }^{19}$ Stoler, Carnal Knowledge and Imperial Power, 44. While Stoler is focusing her theorizing on European colonialism, this model closely mirrors that of antebellum slavery in many ways. The methods utilized to manage, protect, create, and even talk about power of a ruling power over a group of 'Others' look comparable. Evidently it doesn't matter much who the oppressor and the oppressed are. Their practices look the same.
} 
their sexual control had over their race, women sometimes took back the ownership of their intimate selves with extreme methods of reproductive choice. In a time when laws and social customs told them that their bodies belonged to others, they still resisted and claimed themselves.

For these reasons, subjects like rape law, slave breeding, and resistance to slavery through reproductive choice (namely, infanticide and abortion) are important to enslaved women's unique history, and so they are necessary areas of study. More light than before has been shed on these matters in the last couple of decades, but they still require further analysis by historians, as they are necessarily interconnected in the debate over who owned an enslaved woman's body. A debate which began when slavery began, and has not ended still today in the academy. Unfortunately, these necessary areas of study are also among some of the more difficult issues to find discussed by the women themselves; Harriet Jacobs is relatively unusual in her ability to tell us her story herself, in print, through self-narrative. She doesn't follow the generalizations about enslaved women being highly invisible in the historical data because she was highly literate, and because she found a strong, white friend to help her to publish her words. However, other sources are scattered across genres of evidence usually examined by historians of slavery: medical records, legal documents, newspapers, and slave narratives, among others.

This thesis will argue that enslaved women, in spite of their highly controlled lives, claimed their own bodies during a time when society would not have expected it, nor consistently recognized it. It will also aid in the understanding about enslaved women's especially intimate oppression and resistance during antebellum slavery. If we are to understand that bondswomen asserted their own rights to their body, what does this 
mean about the legal, literal, physical, and symbolic claims that were made on their bodies by others? To answer this, I will explore the particular experience of the black slave woman and how this generated their unique methods of resistance. I will examine how a disturbing lack of protection for their bodies from regulation of the time was an attempt to own them, and what the outcome of rape law meant for slave society. In turn, the idea of 'lack of protection' played out in unexpected ways when taken up by activists, when it appeared in legal contests in the court room, and finally, in the familial and social lives of slave communities, as well as in how those families and communities are remembered in oral tradition. Another contribution of this thesis is to further root the historic stigma of criminality pressed onto people of African descent in slavery, extending it to women. My study suggests that enslaved women only entered the courtroom as legal bodies as bad or deviant mothers, emblematically in the Margaret Garner case of 1857. This case consolidated a number of floating associations with slavery and gender around the figure of the bad or deviant mothers, and remains one of the primary points of entry for black women into dominant discourses in the media, social science, and everyday politics.

$* * *$

Research and publications searching for an in-depth understanding of the slave experience did not become popular until the 1970s, and even then women were largely absent from the discussion. Thanks to an upsurge in black feminist scholarship on slavery in roughly the past thirty-five years, research on slaves' experiences began to look at women as an important group to study distinctly, and once this door was opened, generalizations about women's experiences in slavery followed. Crucial to this body of 
scholarship early on were the concepts of women's agency under slavery and of bondswomen as central to U.S. history. Before this time it would be safe to say that most historians and academics in general ignored the fact that bondswomen were individuals with their own pasts. More recent scholarship (in the recent decade) has added concepts of everyday resistance and of the body as an intimate site of control and resource of opposition. ${ }^{20}$ Historians of the past thirty-five years share a number of basic arguments about women under slavery, especially the premise that women are central figures in the antebellum slave system as workers, mothers, and wives, though precise standpoints and methodologies vary among black feminist practitioners.

Angela Davis published Women, Race, and Class in 1981 and became one of the first historians to focus specifically on the experiences of black women. Catching the spirit of this moment in black feminist scholarship, she said that, while scholarly debate on slavery showed signs of "renewed vigor" from the 1970s on, what was still (in 1981) "conspicuously absent" was a book dedicated specifically to truth in the lives of slave women. ${ }^{21}$ Deborah Gray White's 1985 work was among the first to represent an answer to this need, and an important turning point for the study of slavery, pushed forth by a myriad of black feminist scholars in the academy and outside. ${ }^{22}$ Davis and White were among a new group of historians who successfully integrated the history of enslaved women into the established version of slave history. ${ }^{23}$ They argued that enslaved women's

\footnotetext{
${ }^{20}$ Camp, Closer to Freedom.

${ }^{21}$ Angela Davis, Women, Race, \& Class (New York: Random House, 1981).

${ }^{22}$ Deborah Gray White, Ar'n't I a Woman: Female Slaves in the Plantation South (New York: W. W. Norton \& Co., 1985).

${ }^{23}$ Other works which were integral to the early groundwork for theoretical discussion on enslaved women's history include: Gloria Hull, Patricia Bell Scott, and Barbara Smith, eds., All the Women Are White, All the Blacks are Men, But Some of Us Are Brave (New York: The Feminist Press, 1982); See also Hazel Carby, Reconstructing Womanhood: The Emergence of the Afro-American Woman Novelist (New York: Oxford
} 
experiences were inherently necessary in the bigger story of the history of slavery in the United States, that their stories demanded their own telling, and that the absence of their voices from historical record should not remove them from the academic discourse.

Helping to create a more explicit theoretical framework for the history that Davis and White were suggesting we write, Patricia Hill Collins published her text, Black Feminist Theory, in 1990 and continued the dialogue on women's history and how we in the present choose to talk about women with a strong feminist standpoint. She introduced terms that would become important for the work of historians (and others) as she dissected the paradigms of sexism and oppression. Especially important for my own work are her concepts of "controlling images" and "self-definition." 24

Collins describes "controlling images" as those stereotypes that were invented to subjugate black women. These images became part of the ideology of domination, and more specifically, slavery. They were fabricated and then perpetuated as truth, and were "designed [by white society] to make racism, sexism, and poverty appear to be natural, normal, and an inevitable part of everyday life." ${ }^{25}$ Controlling images began to define black women during times of slavery, when antebellum society found power in the ability to explain the enslaved women's place, under their control. The first of these images was that of "mammy," the obedient, kind, asexual domestic servant to her white family. She was the ideal black female in that she accepted her subordination, and this image was

University Press, 1987); See also Darlene Clark Hine, Wilma King, and Linda Reed, eds., We Specialize in the Wholly Impossible: A Reader in Black Women's History (Brooklyn: Carlson Publishing, 1995).

${ }^{24}$ Collins, Black Feminist Thought, 67 \& 114. I also referenced the concept of "self-definition" earlier when discussing Sojourner Truth, but it is important to note that Collins discusses this at some length. Collins also discusses the "intersectionality" of oppression as that place at which multiple oppressions meet. Enslaved women obviously lived at a place of intersectionality where their oppression as women, as blacks, and as slaves collided. "Intersectional paradigms remind us that oppression cannot be reduced to one fundamental type, and that oppressions work together in producing injustice."

${ }^{25}$ Ibid., 68. 
used to rationalize the exploitation of house slaves. In tension with the mammy was the image of the "matriarch," who represented the bad black mother in black homes. She was to blame for any failings that could be found in the family structure within black communities, as well as for any deficiencies in the black children she raised. In contrast, the third stereotype, the "breeder woman," was highly sexualized and believed to be able to breed as efficiently as an animal, and therefore justifiably able to reproduce slaves as needed for her system of oppression (this image would later evolve into the "welfare mother"). The fourth controlling image created under slavery is that of the "jezebel," who is this time highly sexualized and aggressive. The ability to categorize black women as sexually aggressive is key to the perpetuation of enslaved women's sexual exploitation because they were claimed to be promiscuous and at times desirous of the rape that white men continued to dominate them with. These images, taken together, created a framework upon which the ideology of slavery could safely rest. They explained away much wrongdoing sustained by white society, by placing the blame for their racial experience firmly instead on the shoulders of black women. ${ }^{26}$

Collins's concept of "self-definition" is also crucial for my own theoretical framework for this project because enslaved women's ability to build oppositional knowledges meant that they had to first re-invent themselves, to themselves. ${ }^{27}$ They understood that the society that tried to control them did not get to define them exclusively, and they sometimes used self-definition as a way to create an alternate understanding of the claims made on them. As mentioned earlier, Sojourner Truth gives us a clear example of this when she re-defines the word 'woman' for her audience

\footnotetext{
${ }^{26}$ Ibid., 67-78.

${ }^{27}$ Ibid., 10.
} 
members in Akron. This ability to speak back and deconstruct a term that applies to oneself and then to re-define it, therefore creating a strong self-definition, was crucial to black feminist theory, and also helps me to realize that in order to re-define ownership, we must work to deconstruct the old definition and create a new, more nuanced once. ${ }^{28}$

Collins calls self-definition "the power to name one's own reality." ${ }^{29}$ This is quite difficult to do, however worthwhile the outcomes are. Look at "controlling images" like 'mammy', 'jezebel', and 'breeder'. Those terms were ascribed to black women until they were finally deconstructed and new self-definitions replaced them. The concepts put forth in Black Feminist Theory changed how scholars talk about black women's history in a profound way, and the import of Collins's work to the historical dialogue of the late twentieth century can not be overstated.

Although Davis and White published their revisionist works in the 1980s (Collins in 1990), and could be considered dated by now (some 25-35 years later), their work laid the foundation for the more recent investigations into enslaved women's resistance, and therefore my current study of bondswomen's claims to their bodies as well. Davis and White opened the door for discussion of reproductive politics under slavery, bondwomen's resistance, and the unique lives that slave women led, and I will investigate further in these areas, relying on theorizations of the body by historians like Stephanie Camp, who focuses on the body as a site of oppression and resistance, informed by postcolonial theory. Where Deborah Gray White and Angela Davis began the academic conversation on enslaved women's specific experiences, many other noted historians have

\footnotetext{
${ }^{28}$ Ibid., 14-15.

${ }^{29}$ Ibid., 114.
} 
continued in their footsteps, adding to the constantly shifting discussion on bondswomen's history.

Most important for my own re-theorizing about the question of bondswomen's bodily ownership are modern-day revisionist historians like Camp, who offers up the theory of "everyday resistance," as well as the contribution of a thorough rationalization of concepts like the "geography of containment" (slaveowners' methods of physically, geographically attempting to control the bodies of their slaves) and the "rival geography" that resulted (when slaves themselves redefined their own boundaries and resisted their owners' efforts at physically containing them). ${ }^{30}$ Drawing on post-colonial theory, Camp delivers a fresh perspective on the subversive actions that bondspeople countered their oppression with, and she is especially focused on the special ways that women resisted, and the body politics involved. Camp's inclusion of those methods of resistance that might otherwise seem trivial, which she shows instead as central, like covertly appropriating a mistress's finery for illicit late night parties, is important to my own nuanced and re-theorized understanding of the concept of resistance. ${ }^{31}$ She reminds readers that we must take into consideration those modes of resistance that would have been available to enslaved women and not to discount them as inconsequential, but to instead validate and conceptualize them into the discussion on resistance to slavery. ${ }^{32}$

Along with Camp, Dorothy Roberts and Jennifer Morgan have also endeavored to provide research and insight on the oppression that was principally reserved for

\footnotetext{
${ }^{30}$ Camp, Closer to Freedom.

${ }^{31}$ Ibid., 60-92.

${ }^{32}$ Camp's work is most closely connected to my own. She says that her purpose is to "demonstrate how enslaved people claimed, animated, politicized, personalized, and enjoyed their bodies-flesh that was regarded by much of American society as no more than biddable property. Ibid., 62 .
} 
bondswomen and the methods of feminine resistance that resulted. Reproduction, slave breeding, and body politics are central to their arguments (and to mine) making them influential historians of note in my work. Roberts relates to readers the tight control that slaveholders attempted to hold over their slave women, but also tells us that "black women struggled in numerous ways to resist slave masters' efforts to control their reproductive lives. They... fought back rather than submit to slave masters' sexual domination. ${ }^{33}$ Morgan points to many sources that back up claims that enslaved women used abortifacients to control their own reproduction, sometimes as a method of direct and conscious resistance. She challenges those who would disagree, saying that "it has ... been argued that low birth rates among enslaved women can be traced to their refusal to bear children whose future could only hold enslavement. Historians who question or oppose this argument usually do so at least in part out of a sense of disbelief that ... women had the knowledge, as well as the desire, to affect the demography of their communities so radically." 34

One of the main distinctions between rape under slavery and rape in other domains of female oppression in this time period is that black women's oppression and bodies were explicitly commodified, displayed, and circulated across a range of consumers, audiences, and stakeholders. Through photography, newspaper articles and lithographs, medical literature, and even anti-slavery literature and slave narratives, the black female body under slavery has performed a conspicuously large share of the work

\footnotetext{
${ }^{33}$ Roberts, Killing the Black Body, 45.

${ }^{34}$ Morgan, Laboring Women, 113.
} 
of national becoming. ${ }^{35}$ Scholars working in social history strike a balance between a feminist telling of slave history and introduction of new methods of examination, like theorizing the enslaved woman's body. Morgan focuses on labor and reproduction dually, while Roberts' hub is reproduction and liberty. ${ }^{36}$ Both have insights about the centrality of the body, often in its most intimate functions as central, sometimes hidden, and sometimes outrageously public and publicized.

Historian Deborah Willis spotlights this last role of the black woman's body as spectacularly public in both her work on black women's photographic history (which, during slavery, often included a presentation of their intimate bodies captured starkly in photograph) and on her frank discussion of Sarah Baartman, often known as "Black Venus" or "Hottentot," who was quite literally stripped down and put on display for her European audiences, who found her "savage" body to be a sensational exhibit. ${ }^{37}$

Other historians, like Sharon Block and Diane Miller Sommerville, have set the stage for an incisive discussion on the dynamics of race and rape law in the antebellum South, partially by documenting things previously thought to be undocumentable, making their work key to this thesis and necessary for a nuanced understanding of the role that intimate oppression played in the paradigm of resistance and the claims over enslaved women's physical space. ${ }^{38}$ Block provides readers with some pertinent comparisons

\footnotetext{
${ }^{35}$ Deborah Willis and Carla Williams, The Black Female Body: A Photographic History (Philadelphia: Temple University Press, 2002); See also Deborah Willis, Black Venus, 2010: They Called Her "Hottentot" (Philadelphia: Temple University Press, 2002), Painter, "Representing Truth," 461-492, and Steven Weisenburger, Modern Medea: a Family Story of Slavery and Child-Murder from the Old South (New York: Hill and Wang, 1998).

${ }^{36}$ Morgan, Laboring Women; Roberts, Killing the Black Body.

${ }^{37}$ Willis and Williams, The Black Female Body; Willis, Black Venus.

${ }^{38}$ Block, Rape and Sexual Power; Sharon Block, "Lines of Color, Sex, and Service: Comparative Sexual Coercion in Early America," In Sex, Love, Race: Crossing Boundaries in North American History (New York: New York University Press, 1999), Sommerville, Rape and Race.
} 
between the causes and ramifications of rape of Native American women and that of African American women. She argues that social and economic influence translated into an ability to demonstrate sexual coercion on the bodies of women who were to be seen as having lower racial status. As a result of the fact that those who held the most influence in early America were the ones perpetrating the rape, this violent act was "explicitly racialized through the early American legal system" and enslaved women especially found that verbal, physical, or even written expressions of protest and opposition to sexual coercion held no enforceable claim on the society that sought to control them. ${ }^{39}$ Block also provides us with study of relevant court cases related to the study of the history of rape in antebellum history, further establishing her usefulness to my purposes. Sommerville works to remind readers that the boundaries of gender and class were also particularly important to the ways that charges of rape were handled. She examines closely the text from many rape trials in Virginia and North Carolina in the twentieth century with some surprising findings. Focusing on trials where white women accuse black men of rape, she finds that, instead of being driven by an irrational fear of black rape being perpetuated on white women (as one might expect court proceedings to have been racialized), there were more factors at play there, including the class and previous reputation of the white accusing woman in those cases. ${ }^{40}$ In other words, the modern controlling stereotype of the black male rapist might have actually been forged out of an uneven historical story, instead of from a static premise, as we might have assumed.

\footnotetext{
${ }^{39}$ Block, Rape and Sexual Power, 202-203.

${ }^{40}$ Sommerville is concerned with the common misunderstanding regarding the effect that fears about interracial sex (when the man was black and the woman was white) had on judicial proceedings in antebellum history. She purports that, while those black men who were convicted of raping white women were often executed for their crimes, it was not until the 1880's and the Reconstruction Era did this irrational fear lead white communities to carry out justice against black men without any legal proceeding at all. Sommerville, Rape and Race.
} 
Just in the past year, Gregory Smithers has produced a pioneering study on slavebreeding. His emphatic discussion of the certainty of slave breeding, as well as his thorough use of his sources (the WPA slave narratives) makes his work essential for my own, as I too rely heavily on slave narrative. Smithers cautions readers against making the common mistake of deciding what is important and true in history based on the sources that appear effortlessly in front of us in modern libraries and repositories. In this case, he is referring to the unfortunate misconceptions (even among the academic community) about the very existence of slave breeding. He points out that the existence of this forced breeding has never been a question among the African American community, who either experienced it or have heard oral history regarding its reality passed down from generation to generation. However, due to the gendered and racialized methodology that the archival records took on in pre-civil war America, and the resulting lack of clear "proof" regarding slave breeding, many historians had not accepted it as a common or even real occurrence in times of antebellum slavery. ${ }^{41}$ As Smithers adamantly points out, many of the narratives that slaves and ex-slaves have left us (some from the WPA slave narrative collection and some from elsewhere) mention the use of slave breeding as a very real method of maintaining and expanding the population of some slaveholders after 1808 (when the international slave trade was abolished and the responsibility to reproduce began to shift to the enslaved who were already in population in the South). While the topic has remained strangely controversial even among more modern historians, Smithers successfully pushes this part of slave history to the front of

\footnotetext{
${ }^{41}$ Gregory Smithers, Slave Breeding: Sex, Violence, and Memory in African American History (Gainesville: University Press of Florida, 2012), 3. Smithers also admits that previous historians may have generally defined slave breeding in narrower terms, and due to lack of explicit economic and demographic proof they rejected the theory.
} 
the academic discussion, insisting that "it is important to keep in mind that the details, experiences, and emotions of human life are rarely found on the bottom line of a slave ship's manifest or a plantation owner's account book. Sources of this nature often make it difficult to grapple in detail with the violent sexual encounters that accompanied slavery. $^{42}$

I began this discussion with Jacobs, but in some ways her book, published in 1861, was overshadowed at the time not just by the civil war but, in terms of its intellectual and cultural engagement, by the widely publicized and sensational case of Margaret Garner. Garner was a fugitive slave mother who dramatically committed infanticide in the name of keeping her child from slavery. Though this iconic case has been regularly interpreted by scholars and artists (like novelist Toni Morrison in Beloved), Steven Weisenburger gives a more comprehensive account of the story of emblematic Margaret Garner than earlier scholarly works. His work has been helpful to my understanding of which historical players may have used Garner figuratively when it suited their purposes. Abolitionists and pro-slavers alike claimed symbolically her as their symbol of what was wrong with the system, or what was wrong with the slave (respectively). This is a clear example of an enslaved woman's body being claimed by others in the name of their cause, but at the heart is also a story of a bondswoman who claimed herself and her children's bodies, in spite of her circumstances, a point downplayed by Weisenburger. He focuses on the ways that this singular happening, from this one slave woman, became center stage and spotlighted by a society that normally ignored her very existence as more than property. He also argues that the story of

\footnotetext{
${ }^{42}$ Ibid.
} 
Margaret Garner "symbolized slavery's awful, violent power over and within slave families," accenting her lack of power. ${ }^{43}$

Some of the most important (and more common) spaces where enslaved women's bodies became highly visible and public in the decades before the Civil War were in the slave trade itself, notably the coffle and the auction block. The auction block was a prominent metaphor in antislavery discourse, figured prominently on the masthead of William Lloyd Garrison's Liberator for example. ${ }^{44}$ In these spaces, the commodification of women's bodies, especially their reproductive power as mothers, servants, and potential concubines, was most prominent, perhaps even emblematic. In Soul by Soul, and again in a compilation of essays titled The Chattel Principle, Walter Johnson provides us with work that grapples with the details of the internal slave trade and slave markets, where slaves experienced some of the most blatant moments of literal claim being laid to their bodies. In these settings, "their bodies were pieced out, priced, and sold." 45 While Johnson does not choose in his own work to speak much to the gendered oppressions that enslaved women faced, focusing instead on the more general experience, minutiae and inner-workings of the slave market, he does remain gender sensitive, giving us meticulous accounts of how black female bodies were interrogated, manipulated,

\footnotetext{
${ }^{43}$ Weisenburger, Modern Medea, 8.

${ }^{44}$ William Lloyd Garrison (founder of the American Anti-Slavery Society) founded the abolitionist weekly newspaper, The Liberator, between 1831-1865. Many of the most influential abolitionists contributed to the paper. The inhumanity of the auction block was one of many cornerstones of abolitionist discourse, and the details of its specifically disgusting methods put front and center in an effort to create sympathy for the enslaved population - and to eventually effect their freedom. The masthead for the newspaper showed the image of a mother and her children being separated and sold off on the auction block.

${ }^{45}$ Walter Johnson, ed., The Chattel Principle: Internal Slave Trade in the Americas (New Haven: Yale University Press, 2004), 6.
} 
abused, and claimed in this process. ${ }^{46} \mathrm{He}$ also accredits slaves themselves with some agency in the slave market, pointing out that they could at times affect their sale and even position themselves to have some influence on who their new proprietor might be. ${ }^{47}$

Arguing that activism was more central to the story of bondspeople than they are given credit for, and using legal treatises, court cases, and statutes, along with oratory, and slave narrative to find what she calls "counternarratives of activism" lurking below the surface, Christina Accomando's work points out the "legal fictions" that resulted from the laws that governed slaves, and works to deconstruct these fictions. Her work aids me in my understanding of the methodology necessary when searching for the pieces of the story that are below the surface in antebellum legal records. Especially helpful is her careful consideration of the crucial court cases and slave law that contributed to rape law as applicable to enslaved women, and her nuanced understanding of the tightrope that judges walked when trying to navigate a system fraught with contradictions. This often meant that they were expected to (and did) uphold the legal inconsistency that slave men and women were nothing but property until they were charged with a crime, when they were considered worth the notice of the court long enough to be criminals. ${ }^{48}$

Directly related to my employed methodology is also the work of Jean Fagan Yellin. Yellin pressed ahead against uncertainty when other scholars dismissed the accuracy of Harriet Jacobs's narrative, Incidents in the Life of a Slave Girl (a good illustration of a strong enslaved woman who certainly claimed her own body and

\footnotetext{
${ }^{46}$ Walter Johnson, Soul by Soul: Life Inside the Antebellum Slave Market (Cambridge: Harvard University Press, 1999), 83-144.

${ }^{47}$ Johnson, Soul by Soul; See also Johnson, The Chattel Principle.

${ }^{48}$ Christina Accomando, "The Regulations of Robbers": Legal Fictions of Slavery and Resistance (Columbus: The Ohio State University Press, 2001), See also Christina Accomando, "'The Laws were Laid Down to Me Anew": Harriet Jacobs and the Reframing of Legal Fictions," African American Review, Vol. 32, No. 2 (Summer 1998), 229-245.
} 
freedom in many ways), and her perseverance proved worthwhile. After the text itself was lost in the shuffle of the civil war, having been originally published in 1861, it went unrecognized as an oral history (some believing it to be a fiction). Yellin spent time laboriously fact checking the document, and in the end edited and helped find publication for what was a previously lost text. Today, that text serves as one of the few from enslaved woman in antebellum history, an extraordinary contribution that can not be overstated in terms of import. ${ }^{49}$ Reading Jacobs's words and finding them full of awareness, self-worth, and resistance to her domination reminds readers that narrative is a rich and worthwhile historical source. Narrative is a powerful resource because it retrains us to hear the meaning that authors ascribe to their experience and not just the numbers.

While research and publication including slave women's history is much more firmly embedded in academic discourse, it is still not granted equal purchase alongside masculine slave history. This is likely, in large part, due to the lack of obvious, traditionally verifiable primary sources available on enslaved women's lives. Indeed, in "Women, Slavery, and the Atlantic World," Brenda Stevenson notes the still "daunting" nature of this research, despite the internet and new databases "because of the difficulty of releasing the voices of these women bound in such texts" produced by owners and traders and observers, as well as "because of the diversity of ... enslaved females' experiences, cultures, and perspectives." ${ }^{50}$

In this observation, Stevenson echoes Deborah Gray White's observation of decades ago: "Slave women were everywhere, yet nowhere." Despite having access to

\footnotetext{
${ }^{49}$ Jacobs, Incidents in the Life of a Slave Girl.

${ }^{50}$ Brenda E. Stevenson, "Women, Slavery, and the Atlantic World," The Journal of African American History, Vol. 98, No. 1, Special Issue (Winter 2013), 1.
} 
internet and many painstakingly assembled databases such as Documenting the American South, Gray and Stevenson acknowledge that enslaved women were ever present in the physical world of antebellum slavery, but their lives are nearly impossible to find in writing from the time ${ }^{51}$ These concerns remain quite accurate, and our understanding of black female slaves' history has suffered the consequences; remaining partial and incomplete.

Enslaved women living in the antebellum United States survived a heavily restricted existence. Since it was illegal for slaves to be taught (or to learn) to read and write, these women left little written record of their lives. This, of course, limits a researcher on what methodology for a study of bondswomen must look like. While it is true that the sources available are, in this regard, unique and not as numerous as one would like, it certainly does not mean that we can not study what is available in the way of narratives, court reports, newspaper articles, plantation records, and other pieces of the methodological puzzle to gain a nuanced understanding of the ways that women's intimate oppression and resistance pervaded the particular system of slavery.

Adding to the problematic issue of sources, slave women's particular experiences are easily overshadowed by the overwhelming amount of literature on male experience. This is especially clear in the area of resistance to slavery, when masculinist and political modes of rebellion (like mutiny, escape, and murder) fill numerous volumes, and more feminine methods remain part of an unappreciated history. ${ }^{52}$ Historians must then be

\footnotetext{
${ }^{51}$ White, Ar'n't I a Woman, 23, See also Stevenson, "Women, Slavery, and the Atlantic World," 1, See also Documenting the American South, at www.docsouth.unc.edu.

${ }^{52}$ For other authors who contributed to the valuable masculinist literature on resistance to slavery in this general time period see John W. Blassingame, The Slave Community: Plantation Life in the Antebellum South (New York: Oxford University Press, 1972), Eugene D. Genovese, Roll, Jordan, Roll: the World the 
especially creative and diligent when attempting to understand what their particular selfownership looked like.

A successful history of enslaved women's experiences in the antebellum south (1830-1861) would, without doubt, preferably be created from their own voices. Of course, as has been previously mentioned, this is a thorny business to undertake, as the politics of slavery established a purposeful, and nearly complete, exclusion of their voices from writings of the time. With the understanding that all voices are in a sense mediated enslaved women's complex history can, however, be sought out, recognized, and grappled with, and even gingerly reconstructed if some creativity is used in regards to the accounts that are available. These accounts are primarily found in whites' autobiographies, log books, newspapers, laws, reports, publications, and legal documents. Enslaved women's voices can also be heard more clearly in their own oral histories, as they have told them to others to record or have published post-abolition. These invaluable narratives and autobiographies are perhaps the only places where we can hear the women themselves relate their experiences. The best and most accessible examples of this are the WPA Slave Narratives, the published autobiography of Harriet Jacobs, and the collection Six Women's Slave Narratives, which includes one slave narrative published in the antebellum time period and two additional narratives published during or just following civil war. ${ }^{53}$

Slaves Made (New York: Pantheon Books, 1974), Herbert Aptheker, American Negro Slave Revolts (Millwood, N.Y.: Kraus Reprint Co., 1977), and Kenneth Stampp, The Peculiar Institution: Slavery in the Antebellum South (New York: Knopf, 1956).

${ }^{53}$ Works Progress Administration, Slave Narrative Collection [1936-8], Jacobs, Incidents in the Life of a Slave Girl, and Henry Louis Gates, Jr., ed, Six Women's Slave Narratives (New York: Oxford University Press, 1988). 
However imperative I believe these sources to be, I feel that the issues of mediation also are in play here. The dependability of various oral primary sources has long been at the center of a key debate about how historians choose to relate and document history. Oral history, including interviews, autobiographies, and narratives, have been under special scrutiny in the academic community for several decades. ${ }^{54}$

I am particularly mindful of the scholarly questioning of the reliability of the Works Progress Administration Slave Narratives Collection from the 1930s, but I would argue that these narratives are especially important to the telling of a fuller history of slavery because of the sheer volume of the interviews, their accessibility to academics and the public, and their distinctive ability to offer personal glimpses into the actual lives of slaves (women especially, who were otherwise excluded from this history). Verifiability and corroboration can prove tricky standards of evidence when historical figures attempt to enunciate matters that were dangerous, suspect and denied in their own time, and even ours.

Oral history has been central to African American history, both in popular and academic practice for some time as well. This is partially due to the fact that the African American community passed down familial and cultural history using oral methods, and partially because, in the study of history, the recording and retelling of oral histories have proven to be some of the only methods that preserve a voice where they were previously silenced. Directly linked to this debate is the issue of how to accurately use oral history in the retelling of the history of slavery.

\footnotetext{
${ }^{54}$ John W. Blassingame, "Using the Testimony of Ex-Slaves: Approaches and Problems," The Journal of Southern History, Vol. 41 (1975), 473-492.
} 
Some historians, such as John Blassingame, have sometimes chosen to illuminate the more common inconsistencies found in the WPA collection, but have ultimately continued to defend the collection's soundness as a primary source for the history of slavery. ${ }^{55}$ Blassingame argues that, although these forms of oral history come with their own inconsistencies and flaws, they can and should still be viewed as legitimate forms of historical documentation. In the specific case of the WPA Slave Narrative Collection, even when methodology of collection (especially transcription technique) turns out to be problematic, the source is still important and distinctive, and should not be invalidated. This is especially true in the case of African American history, since sources left behind that include the words of slaves are severely limited. Those few sources that do include this important piece of evidence that is crucial for puzzling out truths that are otherwise not verifiable.

Historians are becoming more familiar and accepting of oral history, and their use of the WPA Slave Narrative Collection has shown that they can still appreciate the need for sources where narrators are able to tell their own stories, and their own histories. Until the late 1970s the narratives were largely untouched, and for at least seventy years (1902 -1972) only a couple of the studies done on slavery drew any of their information from these rich sources ${ }^{56}$ After this time, historians, especially African American historians, gladly utilized the slave narratives and their acceptance as sources in the academic community did rise. This may be partially due to the fact that the accuracy and substance of the narratives was never disproved and much of the contextual information given in the interviews was accepted as fact-based.

\footnotetext{
${ }^{55}$ Ibid.

${ }^{56}$ Ibid., 473.
} 
When the WPA Federal Writer's Project took on the Slave Narrative Collection project in the 1930s, oral history was still a largely ignored form of historical documentation, but several efforts at collecting the oral testimony of slaves had been initiated. The reasoning behind the suddenly awakened interest in the oral testimony of slaves was complex. It was at least in part due to the knowledge that those blacks that were still alive from the days of slavery were dwindling, and partly due to the contention among some academics about the level of contentment that slaves felt with their previous roles as oppressed (some academic discourse at this time purported that they were highly content, but not everyone agreed). ${ }^{57}$

The first of these efforts was seen in 1929 at Fisk University and Southern University (separately), but the majority of these results were never published. In 1934 Lawrence Reddick (who had previously studied at Fisk) proposed the continuation of the ex-slave interview project to the Federal Emergency Relief Administration officials who were looking for new ways to employ U.S. citizens who were out of work during the Depression. The New Deal Administration had provided funds for FERA and others to underwrite projects such as these. The project began and failed within a couple of years $(1934-1935) .^{58}$

By the next year the similar Slave Narratives Collection project had begun in several states under the umbrella of the Works Progress Administration's Federal Writer's Project. Originally the project was proposed to have been conducted by black workers, but in the end a higher number of white than black interviewers and employees

\footnotetext{
${ }^{57}$ Norman R. Yetman, Life Under the "Peculiar Institution": Selections From the Slave Narrative Collection (New York: Holt, Rinehart \& Winston, 1970), 339-355. See also Blassingame, "Using the Testimony of Ex-Slaves."

${ }^{58}$ Ibid.
} 
were recruited by the WPA. The interviewers were instructed lightly with materials sent from the director of the project at the Federal Writer's Project's national office (including proposed interview questions and some guidelines). However, the degree to which these proposed materials were used varies greatly between states. ${ }^{59}$

In the end over 2,300 interviews were collected for the Slave Narrative Collection, and were deposited into the Manuscript Division of the Library of Congress national archives. Included in the collection were over 500 photographs and over 1,000 other pieces of history from this time period. ${ }^{60}$

Once the collection was compiled and became open for use in the Library of Congress, it still took some time before researchers and historians recognized its importance or used it to understand the history of slavery. The first to do this was Benjamin Botkin, whose 1945 book Lay My Burden Down utilized many excerpts from the collection to introduce the import of this new oral history to others. ${ }^{61}$ The next major publication to use the collection was Norman Yetman's 1970 book Life Under the "Peculiar Institution," which included roughly 100 of the interviews from the collection in their full form. ${ }^{62}$ Finally, in 1972, the entire Slave Narrative Collection was published as The American Slave: A Composite Autobiography, edited by George Rawick. ${ }^{63}$

\footnotetext{
${ }^{59}$ Yetman, Life Under the "Peculiar Institution," 339-355 and Blassingame, "Using the Testimony of ExSlaves." For copies of memorandums, suggested interview questions, and proposed rules to conducting the ex-slave interviews, see Works Progress Administration Slave Narrative Collection, "Born in Slavery: Slave Narratives from the Federal Writer's Project, 1936-1938," Library of Congress, Online at http://memory.loc.gov/ammem/snhtml/snhome.html.

${ }^{60}$ Works Progress Administration Slave Narrative Collection, "Born in Slavery."

${ }^{61}$ B. A. Botkin, Lay My Burden Down: A Folk History of Slavery (Chicago: University of Chicago Press, 1945).

${ }^{62}$ Yetman, Life Under the "Peculiar Institution."

${ }^{63}$ George P. Rawick, ed. The American Slave: A Composite Autobiography (19 Volume Set) (Westport, CT: Greenwood Publishing Co., 1972) [compiled from interviews submitted to the Library of Congress in 1941].
} 
For modern historians, it is crucial, yet difficult to know how to utilize the WPA Slave Narrative Collection, as it is with any oral history. There are no guidelines to follow when making use of these sources. In the case of the WPA collection, there is historical context that should be recognized when analyzing the narratives. Yet, quantitative analysis of the narratives generally does not provide us with much new information.

While the methods of oral history used in obtaining these narratives is admittedly questionable as inconsistent, the resulting testimonies still have accuracy at their core. Not only have the details involved in the narratives remained unchallenged by experts, this specific collection also reflects some other important strengths that other oral slave history generally does not share.

One strength, as was previously mentioned, unlike most other forms of slave history, the WPA slave narratives allow us to read the words of blacks who were themselves once slaves, and notably, many women. ${ }^{64}$ Although the narratives are not necessarily 'verbatim,' they are still near to it, and, over time, have gained credibility among professional scholars as authentic accounts of slavery from ex-slaves.

Also, even though the WPA narratives are criticized due to their late collection (over 70 years after passage of the Thirteenth Amendment, which abolished slavery in United States), their late collection does carry an upside as well. Although the interviewees were elderly when interviewed, and young when slaves, they also did not have reason to dramatize their recollection of events. Those slaves or ex-slaves and their

\footnotetext{
${ }^{64}$ Using the narratives of South Carolina as an example, 42.2 percent of the narrators were women and 57.8 were men. While this is still slightly disparate data then, it is more highly representative of enslaved women than many other sources available. Gerald J. Pierson, The Nature of Resistance in South Carolina's Works Progress Administration Ex-Slave Narratives (Toledo: Dissertation.com Publishers, 1990), 11.
} 
abolitionist editors/ publicists who chose to create oral histories during slavery, were sometimes more focused on wanting to convince the public about the inherent evil of the system of oppression and this could be argued to have colored their perception in the narrative or autobiography itself. It also seems more likely that the aged, black ex-slaves would have felt nervous about the highly sensitive nature of these questions during a time of high racial conflict and tension and could have, instead of simply sharing the horrors of slavery, something that they had long been taught to keep to themselves, underreported certain, personal negative experiences. ${ }^{65}$

Although most historians would still recognize these as valid sources, the WPA slave narratives should also be recognized as one of the very few sources on the history of slavery that can be considered primary and outside the explicit antislavery agenda of antebellum decades. Arguably more important still, women's voices can be heard loud and clear within the narratives.

Historians rely on patterns as offering evidentiary power, and the narratives-far flung and variously produced though they were—-reveal significant patterns that demand our attention as scholars. For my own work, one of the crucial patterns we see in the narratives is the distinct ways of remembering slave breeding, sexual coercion, and body politics.

For my purposes, a multi-layered set of primary sources, including all of the before mentioned types, will be utilized. The question of who claimed/owned the bondswoman's body will be examined from several angles.

\footnotetext{
${ }^{65}$ Smithers, Slave Breeding, 101-2, and Stephanie J. Shaw, "Using the WPA Ex-Slave Narratives to Study the Impact of the Great Depression," Southern Historical Association, Vol. 69, No.3 (August 2003), 626.
} 
In chapter two, I will scrutinize the laws related to rape that were employed in court cases in the antebellum era (and some from before this time that set the stage) which allowed enslaved women's bodies to be violated without recourse, and some of the legal and social tensions so produced. In chapter three, I will inspect a range of sources (including multiple newspaper articles, a plantation journal, medical publications, abolitionists' journals, and slave narratives) of the period to determine how women claimed ownership of their own bodies through reproductive choice (infanticide and abortion) and resisted the system itself. By the conclusion of this thesis I hope readers will come to understand the variable ways that enslaved women claimed ownership of themselves. The progression of this thesis will be not be chronological in nature, but instead thematic. The weight and direction of this evidence points to a subtle but clear pattern: enslaved women primarily enter official discourses as criminals, rather than as victims. Indeed, powerful authorities actively reject the construction of enslaved women as victims deserving. When considering my geographic constraints I ultimately decided that, partially due to the scarcity of surviving documents and partially owing to the continuities and similarities that I found in these sources, it would be most beneficial not to limit my work to any smaller region or group of states. The reach of slavery extended throughout the plantation south, and influenced its northern neighbors heavily as well. Therefore, I have chosen to share research from all over the south, without limiting myself with state or region boundaries. I look at the 1830s-1850s from various angles to accumulate fresh evidence about resistance. My argument has to do with ways in which this resistance has been remembered or forgotten, manipulated or amplified, mainly in the past, but also in the present. 
To make use of the myriad primary sources necessary to paint a clearer picture of enslaved women's particular history, a more open-minded and yet, detail-oriented, methodology must be employed by the researcher. Hodes reminds us that when writing a history of secretive acts and defiance, stories are found in fragments, the "shards and bones, parts of conversations, and laconic responses to frightening questions." ${ }^{66}$ To piece together evidence then, we will need a flexible, hybrid approach to the evidence, the oral as well as the written, and what is unsaid as much as what is said. Written words are often presumed to be more easily subjected to verification than oral accounts, but they can all lie, and they can all tell us the truth. ${ }^{67}$ Camp also usefully reminds us that " many dimensions of slave resistance remain opaque." And furthermore, that "the valorization of the organized and the visible veils the lives of women... It is, therefore, particularly important to look to the subtler forms if we are to understand women's lives in and resistance to slavery. ... A shift from the visible and organized to the hidden and informal, as well as rigorous attention to personal topics that, for enslaved women, were also political arenas." 68

So, in order to answer the question, "Who owned this body?" we must look for nuance in even the most basic places. For example, when reading case law from the antebellum era, we must understand that we will not find the words of enslaved women themselves, since they were not allowed to testify in court. However, this does not mean that we can not gain much insight into their particularly silenced place in the court system of their time. One must read between the lines to see what the legal discourse implies

\footnotetext{
${ }^{66}$ Hodes, White Women, Black Men, 1.

${ }^{67}$ Gwendolyn Etter-Lewis and Michele Foster, Unrelated Kin: Race and Gender in Women's Personal Narratives (New York: Routledge, 1996), 8.

${ }^{68}$ Camp, Closer to Freedom, 3.
} 
about the position of enslaved women. Much of my methodology will center around the idea of hearing what is not said, just beyond what is directly said.

Grappling with the silences of primary source evidence is a large component of the work that I set out to do in this thesis. Since slave women were mostly omitted from the written record of their time," in seeking to find that resistance which was not made public (as opposed to many masculinist modes, which can more easily be identified), I had to track the stories of intimate oppression and resistance. Since few new primary sources are likely to avail themselves, "we need innovative ways to read our existing ones." ${ }^{69}$ Intimate oppression happens in intimate spaces so slave market sales ledgers, bills of sale, quantitative records recording populations, and so on are generally not going to be as valuable to my work as a narrative told by an ex-slave woman. This is not to say that the stories I need to get at will never appear in public record, as the story of Margaret Garner illustrates, but I can not assume that they can be found there in any real detail.

The Margaret Garners and Harriet Jacobs' of slavery's history are few and far between. If historians hold out for their neatly arranged and publicly shared accounts we will miss quite a lot. In light of the evidence available, I disprove that rape was never a public or political matter because the laws and the few court cases we do see tell us differently. Rather, rape was discussed right in the courtrooms of antebellum America. Even so, while we can see that slave rape then became, at times, a public affair, these cases are anomalies in a sea of typically shadowed or secreted occurrences. Similarly, infanticide was an act usually whispered about, sometimes written about, and rarely put on display. This doesn't mean there are no exceptions. These are all illustrations of the

\footnotetext{
${ }^{69}$ Ibid., 2.
} 
submerged but present tactics of the enslaved to act and make choices when no good ones were presented by circumstance.

Meanwhile, if black women's particular experiences and words are often easy to overlook by norms of cultural power and narration in U.S. culture, their bodies were (and are) not. Their bodies were, in contrast, often put on public display by the powerful, for their own ends. We can see this in discussions of the degrading slave markets of the south. ${ }^{70}$ In the photographs taken in the nineteenth-century (often of white families with black help or of nude black slaves made to pose for insistent masters or photographers). ${ }^{71}$ And sometimes in even more obviously broadcasted settings. ${ }^{72}$ Willis and Williams have taken great care to relate to us the way that black women, including many enslaved women, were represented in photograph and art of their time. They say that "Virtually always when she is depicted she is either a sexualized mythology or a neutered anomaly, defined by her sexuality or lack of it." ${ }^{73}$ In considering photos taken of slave women in 1850 by photographer Joseph T. Zealy, they point out that the way that the women were

${ }^{70}$ Johnson, Soul by Soul.

${ }^{71}$ Willis and Williams, The Black Female Body.

${ }^{72}$ Willis, Black Venus, 2010 and T. Denean Sharpley-Whiting, Black Venus: Sexualized Savages, Primal Fears, and Primitive Narratives in French (Durham, N.C.: Duke University Press, 1999). Quotes below on pages 17-27. See also, Willis and Williams, The Black Female Body, 60-61. The most extreme example of this comes out of Europe, but it highly applicable to my theorizing on the publicized black woman's body. The previously mentioned Sarah Baartman ("Black Venus" or the "Hottentot" as she was often calledSaartjie as she was named in Africa) was a South African woman who was brought to Europe, highly advertised, stripped down, and put on display so that she became the epitome of the sexual savage. She was exhibited in both France and England for over five years and Sharpley-Whiting says "most nineteenthcentury spectators did not view her as a person or even human, but rather as a titillating curiosity, a collage of buttocks and genitalia." Also that, "For the scientific community she provided the missing link in "the great chain of being," the crucial step between humanity, that is, Europeans and animals." Naturalist Georges Cuvier certainly believed that last part, and this resulted in an obsession he developed for her. In 1815 Cuvier and a team of zoologists, anatomists, and physiologists examined Baartman's body, referencing her as an animal in their printed reports. When she died at the end of that year, Cuvier rushed forward to make a plaster of her body, and followed with a report on her "hottentot apron"—a hypertrophy that is an over-development of the labia minora." Obviously sexualized, publicized, and commodified, the body of Sarah Baartman proves an extreme example of the intersectionality at which black women survived.

${ }^{73}$ Willis and Williams, The Black Female Body, 2. 
forced to pose in a marked state of undress in order to bare their naked breasts for "scientific" purposes effectively reduces their humanity and command when it came to the depiction of their own bodies. They argue that the "sight of their clothing unceremoniously pulled down to display these sexual characteristics is more revealing and ultimately more exploitive of their bodies than their nudity would be. Signifying undress rather than nudity, the state of their clothing emphasizes the unnatural and humiliating aspect of their condition. ${ }^{174}$ Willis is making the point that these women have been handled, exposed. While many bondswomen might have found their experiences with being photographed as similarly exploitive, sometimes the images of slaves and free black women could also be used as weapons to combat the system of slavery.

Sojourner Truth used photography to further herself and what she believed in and pushed back against stereotypes with pictures and with words in her life. She commissioned a self portrait and sold it with the caption "I sell the shadow to support the substance," choosing to use her body and her self-image as a way to support the antislavery cause as well as to support herself financially. She "carefully orchestrated her self-presentation, never portraying herself as a slave; instead her dignity defied the injustices of slavery," Painter argues. ${ }^{75}$ While she sought to control and manipulate her own image, Truth never allowed whites to reduce her import to her body parts. She was very aware of the control over her body and what power that could carry. Truth claimed

\footnotetext{
${ }^{74}$ Ibid., 22-23.

${ }^{75}$ Ibid., 84.
} 
herself in the idiom of pious and industrious womanhood normative for the mid-Victorian era. ${ }^{76}$

When these women, themselves, chose to claim their bodies in the face of a range of audiences, how can we not go in search of their words, even if they are hidden between the lines? This thesis strives to find their ownership of themselves in words, memories, and struggles of resistance and making them heard in the present.

\footnotetext{
${ }^{76}$ Willis and Williams, The Black Female Body, 85; See also Painter, "Representing Truth," 461-492. During her Akron, $\mathrm{OH}$ speech, Truth was brazenly asked by a white man to bear her breasts to the crowd so that they could determine whether or not she indeed a woman as she claimed. She refused to directly acknowledge the lewd demand.
} 


\title{
Chapter 2
}

"Regulations of Robbers",77:

Legalized Rape of Enslaved Southern Women in Antebellum U.S. History

\section{Under the United States Constitution a black man had no rights which the white man was bound to respect...}

\author{
Chief Justice Roger B. Taney $(1857)^{78}$
}

A slave has no legal status in our courts, except as a criminal...

Judge R. W. Walker (1851)

As discussed in the introduction, Harriet Jacobs recognized that when Chief

Justice Taney delivered this opinion during the court case Dred Scott v. Sandford in

1857 , he was not only speaking about black men. ${ }^{80}$ Black women, and especially

enslaved women, also had no rights which white men (and white society in general) were

\footnotetext{
77 This is my own perception of the idea of "regulations of robbers" that Harriet Jacob's employs in her book. In Incidents in the Life of a Slave Girl this term is meant to describe how the law labeled Jacobs (and her children) as property... thereby regulating the robbing of their freedom. This idea is fully applicable to regulations in Southern states that allowed, and even condoned, white men's rape of enslaved black women. Jacobs, Incidents in the Life of a Slave Girl, 187.

${ }^{78}$ Dred Scott v. Sandford, as quoted in Higginbotham, Jr., "Racism and the Early American Legal Process," 1.

${ }^{79}$ Creswell's Executor v. Walker, 37 Ala. 229 (1861), 233-4.

${ }^{80}$ Lea VanderVelde and Sandhya Subramanian,"Mrs. Dred Scott," The Yale Law Journal, Vol. 106, No. 4 (January 1997), 1033-1122. VanderVelde and Subramanian discuss the life of the woman who stood "at the eye of the hurricane" of the Dred Scott case. His wife, Harriet Robinson Scott, who was very likely the instigator of his claim for freedom, her own claim having been simultaneously recorded and then swiftly tied up into her husbands. The authors argue that she had the most to lose, the most to gain, the health to live more than a few years past the ruling (Dred was an older man and died within two years of the court case). It seems that many things point to the likelihood that she propelled his case into existence. What happened after they petitioned was unplanned. They became center stage to one of the most important and controversial court cases of their time and their own freedom became secondary to what the ruling might mean for a nation on the verge of division.
} 
bound to respect, and this legal defect was felt keenly with regard to the protection of women and girls' bodies from sexual coercion and brutality.

My chapter title from Jacobs identifies the way that law proclaimed on high could invade the most personal and emotional spaces between human beings, like the relationship between mother and newborn infant. As the introduction emphasized, the intimate with regard to enslaved women, was a crucial site of embattled space that slaveholders, like colonizers before them, meant to dominate, and it played center stage in some antebellum courtrooms. ${ }^{81}$ Claims were made on women's bodies there, sometimes by owners, and sometimes even by themselves (although not in the court records, since their voices were prohibited there). Asking big questions of the courts with regard to who could claim bondswomen's bodies, the answers were those that were deemed necessary to control. This chapter explores several law cases in which the intimate and the stake in defending and protecting that space became discernible and palpable in the historical record, as well as a point of leverage for enslaved mothers in a deck stacked against them.

Within the system of slavery itself, blacks were subjugated in multiple ways, and women found that they especially experienced this intersectionality. They were oppressed as women, as blacks, and as slaves. This was as accurate legally as it was socially. Their status as property or chattel helped to simplify the negating of their human rights by not granting them civil or constitutional rights. Their bodies were claimed legally as property with a bill of sale, markets circulated them as commodities that whites could "own," and

\footnotetext{
${ }^{81}$ Stoler, Carnal Knowledge.
} 
they were constitutionally reduced to $3 / 5$ of a person, and even that only for limited and proscribed purposes. ${ }^{82}$ Slaves were lawfully vulnerable to the most intimate oppressions as well-unguarded from any form of physical coercion that was deemed obligatory by their white owners, and possibly, their black male counterparts as well. In Southern states before the Civil War, the legal system perpetuated, if not encouraged, rape of enslaved women in at least two ways: it deemed any offspring that was conceived in the rape of slave women as a slave, thereby reinforcing the system of slavery through reproduction, and it failed to identify the rape of enslaved women, the brutal claiming of their intimate selves, as a punishable offense, giving men ultimate power over their enslaved female victims. ${ }^{83}$ Jacobs's point about the connection between public laws and markets and a range of intimate entanglements and conflicts is the focus of this chapter, especially in the sphere of sexual coercion.

This chapter will explore the legally sanctioned sexual exploitation of enslaved Southern women and the way that their body's dual role as mothers and necessary reproducers advanced this. It will show how the intimate oppression of enslaved women was condoned, if not regulated through a series of legal precedents. My approach differs from recent appraisals by historians like Diane Miller Sommerville and Christina Accomondo because I will examine the nuanced dimensions of the law as it effected the relationship between enslaved women's body politics, their claims to themselves, and the ways that ALL men could potentially have legal access to their intimate spaces. I also

\footnotetext{
${ }^{82}$ During the Constitutional Convention, which took place in Philadelphia between May 25th and September 17th, 1787, it was declared that $3 / 5$ of the slave population would be counted when deciding what representation in the House of Representatives and what taxation a given state might carry. This was contained in Article 1, Section 2, Paragraph 3 of the United States Constitution.

${ }^{83}$ Roberts, Killing the Black Body, 29.
} 
point out some of the contradictions that Southern states perpetuated in their selective methods regarding criminalization of rape, contradictions that held unanticipated leverage for not only slaveholders and southern white men, but all men—even black men, whether they be slave or free ${ }^{84}$ While black women were left unprotected from the sexual exploitation of their bodies, no matter how violent, black men (slave or free) were punished excessively (often times with the death penalty) for rape and attempts of rape perpetrated on white women. For example, between 1812 and 1849, every single black man charged with rape in the state of Georgia was convicted and put to death. In an even greater span (1755-1865) every black man who was convicted of rape was executed. ${ }^{85}$ Despite findings by historians that excessive policing of black male sexuality in the south was a distinctly post-Reconstruction phenomenon, I take a fresh look at the construction and framing of sexual crime under slavery. These statistics show us how seriously the crime of inter-racial rape was taken by the courts (and therefore, the society) in the plantation south, well before Reconstruction. In particular, the legal and social rituals of claiming of white women's bodies was only to be done by white men. Any attempts for black men, whether they be slave or free, to claim any access or "title" to these bodies was like an act of insurrection and was policed accordingly. While the media frenzy and hyper-mythologizing of black men took place in a later period, but the stringent policing of them and the color line around them has ample precedent before the civil war. ${ }^{86}$

\footnotetext{
${ }^{84}$ Accomando, "'The Laws were Laid Down to Me Anew, 11. Interracial sex was banned but interracial rape was not.

${ }^{85}$ Glenn McNair, Criminal Injustice: Slaves and Free Blacks in Georgia's Criminal Justice System (Charlottesville: University of Virginia Press, 2009), 128.

${ }^{86}$ Sommerville, Rape and Race; See also Mary R. Block, "Rape Law in 19th-Century America: Some Thoughts and Reflections on the State of the Field," History Compass (July 2009), 1391-1399; See also Hodes, White Women, Black Men.
} 
The legal contradictions associated with rape were uneven, but consistent. This attests to the trial-and-error aspect of regulating slavery over the long term, and the law served as one among many methods to protect and control planter interests. Rape law in the Southern states developed gradually, and as it did, it became obvious given resistance and pressure from slaves themselves, over time planter interests and control became more and more visible and explicit in this domain. The key issue in defending sexual crime was not protection of women (even free white women), but instead control over slave populations. Economically benefiting from slavery, Southerners wanted this system to survive, and all methods of domination, especially of the intimate—of the body—aided in this goal. Prohibiting rape of enslaved women could have dangerously suggested the humanity of slaves, and undermined the ideology and system of slavery itself. ${ }^{87}$ Extreme punishments for black men who were found to have raped or attempted to rape white women served to additionally control bondspeople, and retain white superiority through racial purity. ${ }^{88}$ These legal prejudices can serve as a window into the highly unequal and racist Southern racial hierarchy. ${ }^{89}$

From nearly the introduction of American slavery, slavery was a permanent status for Africans, their bodies unendingly claimed by owners, but with the introduction of colonial laws regarding the children of slaves, this perpetual system began to expand greatly. In Killing the Black Body, Dorothy Roberts points out that, "One of America's first laws concerned the status of children born to slave mothers and fathered by white

\footnotetext{
87 Accomando, “"'The Laws were Laid Down to Me Anew”, 11.

${ }^{88}$ Higginbotham and Kopytoff, "Racial Purity and Interracial Sex," 1968-2008.

${ }^{89}$ Bardaglio, "Rape and the Law in the Old South," 756.
} 
men: a 1662 Virginia statute made these children slaves." 90 While the Virginia statute was a colonial law, and the first of this kind, many other Southern states soon followed suit, deciding that children should follow the condition of the mother, and proprietorship of their small bodies would be granted upon birth to their mother's master. Historian Christina Accomondo adds that, "State statues varied, but by the nineteenth century it was fairly uniform principle that the child's status was determined by the mother's. The rule derives from the ancient Roman principle: partus sequitur ventrem," which can be translated from Latin to English as "offspring follows the womb" or " offspring follows the mother." 91 Thomas Cobb, a Georgian who wrote many important works on Southern law and slave law during the antebellum period, described this as well: "From principles of justice, the offspring, the increase of the womb, belongs to the master of the womb."92 This meant that the moment she gave birth, a slave mother was understood to be giving the claim over her child unto her master. However, this understanding may not have included slave women who at times chose to claim their children as belonging to themselves. The space between mother and child, and the bodies of slave children, proved to be another intimate space where enslaved women contested slaveholders dominance, and where struggles would be fought.

In Sojourner Truth's narrative we learn that, when her five year old son was illegally sold away from her (sent to another state) she went immediately to claim his

\footnotetext{
${ }^{90}$ Roberts, Killing the Black Body, 23. See also A. Leon Higginbotham, Jr., In the Matter of Color: Race and the American Legal Process, the Colonial Period (New York: Oxford University Press, 1978), 42-45 $\& 252$.

91 Accomando, "The Laws Were Laid Down to Me Anew," 244; See also Paul Finkelman, ed., Slavery and the Law (Madison: Madison House, 1997), 385, and John N. Cotterell, A Collection of Latin Maxims and Phrases Literally Translated (London: Stevens and Hays Law Publishers, 1913), 51.

92 Thomas R. R. Cobb, An Inquiry into the Law of Negro Slavery in the United States of America (New York: Negro Universities Press, 1968) [originally published in 1858], 69.
} 
little body as her own. There seems to have been no hesitation in her decision to fight for his return to her, as she didn't believe anyone else 'owned' him.

Isabella [Sojourner's birth name], in tones of deep determination [said]-'I'll have my child again.' 'Have your child again!' repeated her mistress-her tones big with contempt, and scorning the absurd idea of her getting him. ' ... Have you any money?' 'No,' answered Bell, '...but ... I'll have my child again.' These words were pronounced in the most slow, solemn, and determined measure and manner. ${ }^{93}$

The use of Partus sequitur ventrem brought with it great implications in Southern social and economic realities. Children from interracial sexual relationships involving black slave men and white women would also follow the condition of the mother, making this small population of mulatto children free. Partially due to the desire to retain white purity and domination, these relationships carried far greater consequences for the black men involved, both in society and in court. On the other hand, children from interracial sexual relationships involving white men and black slave women might be whispered about in the community, but their status as slaves would make them easier to ignore because they were no threat to the societal balance of enforceable power.

White slave-owning men who raped slave women did not have to claim paternity or take parental responsibility for any offspring that resulted from their actions. Still, they would be the ones to most directly benefit from these state laws, as they would find that their actions could actually prove to make them wealthier. ${ }^{94}$ For everyone involved in the system of slavery partus sequitur ventrem meant that "a slave child was property; its birth added to a slaveholder's coffers regardless of the conditions under which it was

\footnotetext{
${ }^{93}$ Olive Gilbert, ed., The Narrative of Sojourner Truth, Dictated by Sojourner Truth (Boston: The Author, 1850), online at http://digital.library.upenn.edu/women/truth/1850/1850.html.

${ }^{94}$ Bardaglio, "Rape and the Law in the Old South," 757; See also Sommerville, Rape and Race, 65.
} 
conceived." 95 Harriet Jacobs says that "slaveholders have been cunning ... taking care that licentiousness shall not interfere with avarice." ${ }^{96}$ In fact, due to the desire to continue reproduction of their chattel, masters, at times, aimed to breed their slaves as much as was possible, yielding the most profit possible over time, and sometimes they, themselves, aided in this slave reproduction. Historian Dorothy Roberts addressed this issue when she pointed out that "legislation giving the children of Black [slave]women and white men the status of slaves left female slaves vulnerable to sexual violation as a means of financial gain. Children born to slave women were slaves, regardless of the father's race or status. This meant, in short, that whenever a white man impregnated one of his slaves, the child produced by his assault was his property. ${ }^{, 97}$ If female slaves had not been socially and legally defined as chattel and thus dismissed from the protection that citizens of their states were afforded, it is possible that legislation would have been more protective of their rights, as under Spanish slavery in Florida. ${ }^{98}$

While rape laws may appear to have been created for the protection of white women, even arguably defined in original supposition as the brutal sexual assault of a chaste white woman by a strange man (increasingly racialized to be a black man in the nineteenth century) it would be hard to argue that white women generally fared much better under the so called protection of the law in antebellum America. The concept of, and judicial regulation against, rape has always had quite a bit to do with the social and

\footnotetext{
${ }^{95}$ Wilma King, "Suffer With Them Till Death: Slave Women and Their Children in Nineteenth-Century America," in More Than Chattel, ed. David Barry Gaspar and Darlene Clark Hine (Bloomington: Indiana University Press, 1996), 159.

${ }^{96} \mathrm{Jacobs}$, Incidents in the Life of a Slave Girl, 76.

${ }^{97}$ Roberts, Killing the Black Body, 29; See also Bardaglio, "Rape and the Law in the Old South," 757.

${ }^{98}$ Jane Landers, "'In Consideration of Her Enormous Crime": Rape and Infanticide in Spanish St. Augustine," In The Devil's Lane: Sex and Race in the Early South, edited by Catherine Clinton and Michele Gillespie (New York: Oxford University Press, 1997), 205-214.
} 
political construction of who gets to be a citizen in America, and not all women were guarded as such in antebellum times. ${ }^{99}$ Antebellum women of any race could find themselves occupying positions in society to which legal protection did not easily extend to. The enforcement of rape law was highly uneven and challenging across the board, but the legal contradictions of rape law meant that many women were highly unrapeable or left lacking a judicial system concerned with their best interests and the protection of their intimate selves.

Free white women shared with free black women an unequal validation under the powers that governed them. Neither race of women was granted full citizenship, and therefore, neither retained true protection of their bodies. While enslaved women were valued only as property owned by a slaveholding master, so white women were valued primarily as containers of the property interests of their husbands and fathers, not as full citizens granted the full security of the law, and even white women who did not fit into these constructions (and who were theoretically citizens in their own right: able to own property, sue in court, or enter into contracts) could be craftily discredited due to their class, reputation, or profession when they came before a courtroom hearing their charges of rape. ${ }^{100}$

Free black women, while no longer considered 'owned' under legal contract like their enslaved counterparts, were still a disenfranchised group without many of the rights that full citizenship would have granted. The decision handed down in Dred Scott v.

\footnotetext{
${ }^{99}$ Estelle B Freedman, Redefining Rape: Sexual Violence in the Era of Suffrage and Segregation (Cambridge: Harvard University Press, 2013), Introduction.

${ }^{100}$ Block, "Rape Law in 19th-Century America," 1393. See also Nancy F. Cott, "Marriage and Women's Citizenship in the United States, 1830-1934," The American Historical Review, Vol. 103, No. 5 (Dec. 1998), 1440-1474, and Sommerville, Rape and Race; See also, Freedman, Redefining Rape.
} 
Sandford reminded them that they were not citizens and did not even have full use of the federal court system from the lower class position which they held in society. ${ }^{101}$ Their tenuous place within society—and the preconceived notions of their promiscuity would not have made it easy for them to claim rape against white or black male counterparts who retained a higher standing in the judicial system than they. ${ }^{102}$

The only group granted power over sexual assault was the most commonly perpetrating group: wealthy free white men. As full citizens (and arguably the only full citizens) they were undeniably the most thoroughly protected by the judicial codes of prewar society. Antebellum women's rights and moral reform advocates were not unaware of the hypocrisy, and some controversy regarding the desire for the existence of a rape definition including marital rape did come out of this time, along with demands for more equality in property rights and the beginning of the demand for women's suffrage. ${ }^{103} \mathrm{It}$ wasn't until well into the twentieth century that feminists, lawyers, scholars and activists redefined the concept of rape to include non-consensual sex with acquaintances and husbands. Until this time, husbands were given authority to claim the bodies of their wives, consensual or not, whenever they so wished. ${ }^{104}$ Enslaved women's status in the South as complete non-citizens allowed legislatures to ignore their right to their bodies for decades. This situation is reflected in court cases from the time period, which helped create and then perpetuated a system of body politics that allowed white men to intimately oppress their female slaves.

\footnotetext{
${ }^{101}$ Dred Scott v. Sandford.

${ }^{102}$ Freedman, Redefining Rape.

${ }^{103}$ Jill Elaine Hasday, "Contest and Consent: A Legal History of Marital Rape," California Law Review, Vol. 88, No. 5 (October 2000), 1385, and Freedman, Redefining Rape, 2.

${ }^{104}$ Freedman, Redefining Rape, 1-3.
} 
The 1829 court case State of North Carolina v. Mann is often pointed out by legal scholars as clearly exemplifying the ways that Southern courts were forced to reshape common laws to protect the system of slavery itself. ${ }^{105}$ In Chowan County, North Carolina, a white man named John Mann shot a slave named Lydia in the back as she fled from one of his abusive, angry tirades. Mann had rented Lydia from Josiah Small (acting on behalf of his minor sister-in-law Elizabeth Jones, who was the slave's actual owner). Upon becoming aware of the inflicted injury of the slave, Small (again acting for Jones) charged Mann with assault and battery of Lydia. The jury of white men at Cowan County Court actually found Mann guilty of these charges, his actions unwarranted and unreasonable, but the case was soon appealed to state supreme court where the guilty verdict was overturned. ${ }^{106}$ Before Justice Thomas Ruffin was the issue as to what offense Mann could be found guilty of. Assault and battery implied violence inflicted upon a person with rights, a citizen. In the end, Ruffin was forced to explain why criminal offenses such as this could not be applied to slaves, who were legally represented as noncitizens. Had Josiah Small and Elizabeth Jones sued Mann for damages to her property, there would have been no dispute, but they had unwittingly (so far as we know) asked a question of the legal system that had yet to be asked. Were slaves to be protected at all from criminal offenses, or did their status as chattel leave them vulnerable and without legal shelter from their oppressors? One must wonder about Josiah Small and Elizabeth

\footnotetext{
${ }^{105}$ Melvin I. Urofsky and Paul Finkelman, Documents of American Constitutional and Legal History: From the Founding Through the Age of Industrialization (New York: Oxford University Press, 2002), 242; See also Mark V. Tushnet, The American Law of Slavery, 1810-1860: Considerations of Humanity and Interest (Princeton: Princeton University Press, 1981), 54, Thomas D. Morris, Southern Slavery and the Law, 1619-1860 (Chapel Hill: University of North Carolina Press, 1996), 190, and Leon F. Litwack, North of Slavery: The Negro in the Free States, 1790-1860. Chicago: University of Chicago Press, 1961. ${ }^{106}$ Urofsky, Documents of American Constitutional and Legal History, 242-5; See also Tushnet, The American Law of Slavery, 54-65; See also Morris, Southern Slavery and the Law, 190-3, and Higginbotham, "Racism and the Early American Legal Process," 8-9.
} 
Jones as well. Did they realize what question they were bringing to the courts and what the implications were? Could they have been decisively on a course to provide legal, bodily rights to the enslaved woman who had been injured? It is unlikely and we may never know the true reasoning for their method of suit, as we do not get to hear their voices in the court records.

Whatever the initial purpose of the suit, in the end Justice Thomas Ruffin found it necessary to utilize this opportunity to fortify control of the system of slavery through the dismissal of Lydia's possible rights, and his eloquently written ruling reflected some important realities about slaves' place in the hierarchy of the South, especially in relation to masters (Mann had hired Lydia and was deemed her temporary master). He discussed the possibility of charging Mann with a criminal offense under the same principles that would be used to guide a trial protecting a child from its parent, or an apprentice from its master. However, Ruffin ultimately decided against this correlation saying that "there is no likeness between the cases. They are in opposition to each other, and there is an impassable gulf between them-- The difference is that which exists between freedom and slavery--and a greater cannot be imagined." ${ }^{107}$ Ruffin understood that the legal system had to see slaves as "other" in order to control them, physically, socially and legally. He went on to explain the actual relationship between the slave and master, affirming: "The end is the profit of the master," and "Such obedience is the consequence only of uncontrolled authority over the body [emphasis added]... The power of the master must be absolute, to render the submission of the slave perfect." ${ }^{108}$ What he was saying is central to the ideology of slavery. Considered as property, slaves could not be treated

\footnotetext{
${ }^{107}$ State v. Mann, 13 N.C. 263 (1829), 265.

${ }^{108}$ State v. Mann, 266-7; see also Higginbotham, "Racism and the Early American Legal Process," 8-9.
} 
protectively by the legal system, especially in regards to their relationships with masters, or it would threaten masters' ultimate authority and the system itself. Also, Ruffin's discussion of "uncontrolled authority over the body" relates to masters" seemingly unlimited access to slave women's bodies. They could lay claim to them however they desired.

This case would prove important for to the law of slavery in multiple ways. It was detrimental to slaves because it reinforced the idea that masters had total control over their slaves' bodies, and that the legal system would not save them from violence inflicted by their masters, no matter how brutal. This rule held as long as the abuse did not take the form of outright murder, for which there were repercussions in some antebellum states (even if a master did the murdering). ${ }^{109}$

By the late 18th century there were laws in place to prevent the killing of slaves (not so much to protect their persons, but to protect their value for their owners). In North Carolina, The Slave Killing Prevention Act of 1774 stated that anyone who was found to have murdered a slave would serve 12 months in prison if it was their first offense (as well as paying the slave's owner their value if the owner was not the murderer), and for the second offense they were to "suffer the same punishment as if he had killed a free man." ${ }^{110}$ This Act was central in the NC case State v. Boon (1801), which resulted in a murderer being given leniency under the law (as it was his first murder of a slave). ${ }^{111}$ In the antebellum period this stance had changed somewhat and in State v. John Hoover

\footnotetext{
${ }^{109}$ State v. Mann; State v. Boone (1801); State v. Hoover (1840); Slave Killing Prevention Act of 1774, Ch. XXXI N.C. Laws. Acts of North Carolina General Assembly, 1774 (March 2, 1774- March 25, 1774), Vol. 23, 931-976.

${ }^{110}$ Slave Killing Prevention Act of 1774, 931-976.

${ }^{111}$ State v. Boone.
} 
(1840) we see that a white master (Hoover) was found guilty of murder in the first degree when he purposefully and cruelly murdered one of his slaves (Mira). Hoover appealed to the North Carolina Supreme Court after his local peers found him guilty, but the result was the same. The death penalty was given and Hoover hung for his crime. What is interesting about State v. Hoover is that it seems that even after Hoover had buried Mira and testified that her death was of natural causes, the community did not allow him to cover up his brutal killing of the slave. They persisted until the body was exhumed and examined to prove foul play. ${ }^{112}$ It seems that a slave's body was available for physical coercion, torture, and rape, but the line had been drawn at murder. The persecution and punishment for slave murder became more severe by the time of antebellum slavery, in large part owing to the monetary loss that occurred when a slave's life was taken. In this case, when a slave women enters the legal record as a victim (an extremely rare occurrence) it is only because of the literal value of her life as a slave. This is key because it alternately illuminates the reason why slave rape was not persecuted or punished severely within the law. When a slave was raped, no one lost monetary value. In fact, the opposite was undeniably true. If she conceived a child in rape, her owner would profit. Mira's body also remained a public object even in death, subject to handling, objectification, and even desecration.

In a time when slaveholders' authority was difficult to question, someone had to come forward and admit that a slaveholder had murdered a slave and face the possibility of repercussions or retaliations. In Sojourner Truth's narrative there is mention of a slave, Ned, who's owner Charles Brodhead murdered him outright for his desire to go and visit

${ }^{112}$ State v. Hoover. 
his wife after harvest had finished (a promise made, but then unkept by Brodhead). Truth says bluntly that "no official notice was taken of his more than brutal murder."113

What Ruffin did not address explicitly in 1829 in State v. Mann is the ambiguity of the actual legal nature of the status of the slave at this time. As one legal scholar put it, "the legal status of the slave was anomalous; they were at once property and persons." 114 More willing to delve into this paradox was one Judge Walker of the Alabama Supreme Court in the 1861 case Creswell's Executor v. Walker, a decision regarding a slaveholder's willing of a trust to some of his slaves. Judge Walker first reaffirmed the already declared idea that "So far as their civil status is concerned, slaves are mere property," but then he went on to point out one of the largest inconsistencies in slave law pointing out that "as soon as we pass into the region of crime, he is treated as a person, as having a legal mind, a will, capable of originating acts for which he may be subjected to punishment as a criminal." ${ }^{115}$ He clarified this by saying that "A slave has no legal status in our courts, except as a criminal..."116 Judge Walker was not the only one to notice the contradictions inherent in the legal system. While many whites chose to see only what they wanted to see, some did point out the inconsistencies so unashamedly perpetuated in the law books and courtrooms.

By 1853, white abolitionist William Goodell had already become "angered by the inherent inequalities of slaveholders' jurisprudence"117 and objected to the fact that "the slave, who is but 'a chattel' on all other occasions, with not one solitary attribute of

\footnotetext{
${ }^{113}$ Gilbert, The Narrative of Sojourner Truth.

${ }^{114}$ Daniel J. Flanigan, "Criminal Procedure in Slave Trials in the Antebellum South," The Journal of Southern History, Vol. 20 (November 1974), 537.

${ }_{115}$ Creswell's Executor v. Walker, 233-6.

${ }^{116}$ Creswell's Executor v. Walker, 233-4; See also Flanigan, "Criminal Procedure in Slave Trials in the Antebellum South," 537.

${ }^{117}$ Flanigan, "Criminal Procedure in Slave Trials in the Antebellum South," 538.
} 
personality accorded to him, becomes 'a person' whenever he is to be punished!’... “He is under the control of law, though unprotected by law..."118 This contradiction between legal status of slaves seeking protection from criminal offence and slaves being prosecuted for crimes had an especially important connection with rape law and the way that bondswomen found themselves intimately claimed. The shield of the law was markedly unwilling to protect enslaved women when it came to rape, as the 'intimate' was held apart from the rest of regulation, and the laws of slavery. Essentially, slave women were able to be physically and mentally victimized without white men having to fear legal recourse. In stark contrast, black men even accused of raping white women would be charged with criminal offense and face severe penalties. ${ }^{119}$

A prime fear of white southern elites was racial mixing between white women and black men, partially because removing a child from a free white mother was difficult to silence and normalize. The evolution of rape law reflects this focus on controlling and limiting white women's sexual access and severely punishing low status men, especially slaves, for such transgressions, thus avoiding the legal entanglements and confused relationships between familial members that could result from these affairs. Historians generally agree that "together with anti-miscegenation laws, rape laws in the South demonstrated the preoccupation of legislators and judges with preventing sexual relations between white women and black men, as well as keeping those two groups in their appropriate places in the social order." 120

\footnotetext{
${ }^{118}$ William Goodell, The American slave code in theory and practice: its distinctive features shown by its statutes, judicial decisions, and illustrative facts (Ann Arbor: University of Michigan Library, 2005) [originally published in 1853], 309.

${ }^{119}$ McNair, Criminal Injustice, 128.

${ }^{120}$ Bardaglio, "Rape and the Law in the Old South," 750.
} 
One of the earlier illustrations of this priority is a Virginian statute from 1769 which explicitly authorizes the castration of black men who are found to have attempted to rape white women. The statute reads: "it shall not be lawful for any county court to order and direct castration of any slave, except such slave shall be convicted of an attempt to ravish a white woman, in which case they may inflict such punishment."121 Disturbingly, Virginia was not the only Southern state to make use of this morbid punishment, and others followed suit. As late at 1855 new acts authorizing this punishment for slaves was passed, this time through the territorial legislature of Kansas, and still only applicable to black men attempting to rape white women. ${ }^{122}$

Enslaved men were also more often executed for convictions of rape when white women were involved. Looking again to Virginia as a model of Southern slave law, it is noteworthy that a 1796 statute abolished the death penalty for all whites who were prosecuted for crimes (excepting first degree murder), but no mention was made to blacks, slave or free, and their executions for these crimes continued. Also, in an 1823 statute of Virginia attempted rape was made punishable by hanging, but again, only for black men (whether free or slave) who attempted to rape white women. ${ }^{123}$

What is implied, but not explicitly stated here is that black women's place in the social order was more firmly secured and they, in such a subordinate place, did not pose

\footnotetext{
${ }^{121}$ For a copy of the 1769 Act see William Waller Hening, ed., The Statutes at Large; Being a Collection of All the Laws of Virginia, From the First Session of the Legislature, in the Year 1619 (Vol. 8) (Charlottesville: University of Virginia Press, 1969) [originally published in 1821], 358; See also John D. Cushing, ed., The First Laws of the State of Virginia (Wilmington: Michael Glazier, Inc., 1982) [originally published in 1783], 9. For more discussion on these morbid laws see Bardaglio, "Rape and the Law in the Old South," 752.

${ }^{122}$ Roberts, Killing the Black Body, 66, and Finkelman, Slavery and Law, 50.

${ }^{123}$ Higginbotham, "Racial Purity and Interracial Sex in the Law of Colonial and Antebellum Virginia," 2008 \& 2013.
} 
such an immediate threat to white domination, and so rarely appear as subject to regulation.

One of the most important cases in rape law regarding enslaved women was heard in 1855 in Calloway County, Missouri. Judge William Hall blatantly exhibited the typical double standard when it came to punishing black versus white men in cases of sexual assault. The case State v. Celia illuminated quite clearly the lack of protection for slave women when their intimate self, through their physical body, was compromised. ${ }^{124} \mathrm{Just}$ as clearly, this case also demonstrated the willingness that existed among those in judicial power to overlook the same kinds of legal contradictions that Judge Walker had found so hard to ignore in 1829. Although much of the contextual background of this case has been detailed through the use of trial records, which included much testimony, we never hear the story directly from Celia. Since, as a slave, she was not allowed to testify in court we only hear "her words" through the testimonies of the men who she spoke with, most notably a white neighbor named William Powell, who recites much of her confession as testimony in the trial, effectively becoming a crucial voice of the defense. $^{125}$

Celia was a fourteen-year-old slave when purchased as property in 1850 by widowed slaveholder Robert Newsom. Soon after her purchase, Newsom began raping her. He continued to do so, staking his claim on her body and keeping her at his convenience in a small cabin just 150 feet from his own home, until June of 1855. Over the course of those several years, Celia bore two children by Newsom, both of whom

\footnotetext{
${ }^{124}$ State v. Celia, a Slave (1855).

${ }^{125}$ Joan Sitomer, "Is a Slave 'Any Woman'? Slavery, Sex, and Claims of Citizenship in State of Missouri v. Celia, a Slave." Paper presented at the annual meeting of the Midwest Political Science Association, (Chicago, IL, Apr 12, 2007), 4.
} 
added to his assets as property via partus sequitur ventrem. In 1855 though, Celia found herself in a dangerous situation. She had begun a relationship with another slave, George, and became pregnant without any surety about who the father was, and therefore what the baby would look like when it was born. While Newson had been ostensibly denying any claims Celia might have had on herself by exerting his force as her master through rape, she decided at this point to claim herself. When she found that she was pregnant again she decided that she would tell Newsom to stop his physical advances. Like Harriet Jacobs was forced to do, Celia made a choice from a place of choicelessness. She defied the laws that told her that she was the property of her master and must submit to him, and she told him "not to come, and that if he came she would hurt him." ${ }^{126}$ Newsom, who undoubtedly didn't think she had any right to make this demand (believing her body to be his property) did not heed her warnings, and suffered the consequences. ${ }^{127}$

Like Harriet Jacobs, Celia must not have believed that her race or legal status gave Newsom unlimited rights to her intimate self and she had meant what she said when she threatened him. On the night of June 23rd, after her final attempt to demand Newsom stop his sexual attacks, she defended herself when he came to rape her in her cabin. She later admitted to hitting him in the head with a stick two times, and then when she realized he was dead she burned him in her fireplace in a desperate attempt to hide the damning evidence. This was unsuccessful and she was charged with Newsom's murder only two days later. $^{128}$

\footnotetext{
${ }^{126}$ Sitomer, "Is a Slave 'Any Woman'?," 3.

${ }^{127}$ Melton A. McLaurin, Celia, A Slave: A True Story (New York: Avon Books, 1991); See also Sitomer, "Is a Slave 'Any Woman'?"

${ }^{128}$ McLaurin, Celia, A Slave. See also Sitomer, "Is a Slave 'Any Woman'?"
} 
While the context of the case is dramatic and interesting to be sure, the real import came from the trial itself. Celia was represented by John Jameson, Isaac M. Boulware, and Nathan Chapman Kouns, who boldly cited a Missouri statute from 1845 that stated plainly that it was a crime to "take any woman unlawfully against her will and by force, menace or duress, compel her to be defiled [emphasis mine]," claiming that she could not be found guilty of murder when it was in self-defense that she acted. Jameson told the court that the words "any woman" in the rape statute should "embrace slave women, as well as free women." ${ }^{129}$ Judge Hall summarily dismissed the concept that Celia could be seen legally as a woman with rights to her bodily boundaries, reminding the court that she was property with regard to the law. Since an owner can not trespass on their own property, Newsom had done nothing unlawful when he raped Celia, and so Celia certainly couldn't be given any leniency in the law as having killed in self-defense. With her defense stricken from consideration, Celia was found guilty of murder in the first degree and sentenced to hang. Since the nineteen-year-old was pregnant at the time, her execution date was set for November, allowing time for the birth of Celia's baby, and thereby attempting to extend the claim of her master's estate on her enslaved status (the baby was stillborn). ${ }^{130}$

Celia's attorney's attempted to appeal to the Missouri Supreme Court for a stay of execution for their client, but when the court finally reviewed the case they declared the ruling sound, saying "there being seen upon inspection of the record aforesaid no probable cause for such appeal... It is thereby ordered by the Court, that an order for the

\footnotetext{
${ }^{129}$ Kathryn Cullen-DuPont, "State of Missouri v. Celia, a Slave: 1855," Great American Trials (2002), and Sitomer, "Is a Slave 'Any Woman?""

${ }^{130}$ McLaurin, Celia, A Slave.
} 
stay of the execution in this case be refused." ${ }^{131}$ Celia was executed by hanging on December 21, 1855, sending some very clear messages to other enslaved women. Enslaved women were not meant to be treated as women at all. Even as the law said "any woman," this did not apply to them. Indeed, to be a slave woman was essentially to not be a woman at all in the eyes of the law, since they were summarily dismissed and left uncategorized with regard to their sex if they were not 'legally a woman.' A 'real woman' who was legally recognized as such would have been protected from unwanted sexual coercion (as long as it was not at the hands of their own husbands), but not slave women. ${ }^{132}$ It seems the legal definition of woman was victim, but enslaved women were property, and the most a white man would ever be said to have done if they raped them was to have possibly 'trespassed' on that property. This didn't apply to owners, who could do sexually what they wished with their human 'property,' without recourse. Enslaved women were not allowed to self-defend their bodies. ${ }^{133}$ While a white woman could be deemed a victim of rape, if she was raped it was her husband or father who would be compensated for her loss of virtue. She was officially acknowledged as a victim in a way that enslaved women were not (she was rapeable in the eyes of the law and could use self-defense to stop a rapist), yet she was still not provided with legal justice when

\footnotetext{
${ }^{131}$ Cullen-DuPont, "State of Missouri v. Celia, a Slave;" See also State v. Celia, a Slave (1855); See also McLaurin, Celia, A Slave.

${ }^{132}$ Freedman, Redefining Rape, Introduction; Block, "Rape Law in 19th-Century America," 1393; See also Cott, "Marriage and Women's Citizenship," 1440-1474; and Sommerville, Rape and Race; See also Hasday, "Contest and Consent: A Legal History of Marital Rape," 1373-1506.

${ }^{133}$ McLaurin, Celia, A Slave; See also, Cobb, An Inquiry into the Law, 99.
} 
violated physically. Again, only the cost to white men was taken into account in the courtroom. $^{134}$

If State v. Celia wasn't clear enough on the lack of protection that enslaved women had against the physical claiming of their bodies via rape, George v. State even further confirmed that they had none. In this Mississippi Supreme Court case from 1859, a male slave named George stood accused of attempting to rape a 9 year-old slave girl, bringing the fight over the 'intimate' again into the courtroom. ${ }^{135}$

Originally George was found guilty of attempted rape by a county court, and was sentenced to death, but the state Supreme Court reviewed the case and bluntly admitted to the lack of protection that slave women were afforded under the law when Judge Harris proclaimed that, "From a careful examination of our legislation on this subject, we are satisfied that there is no act which embraces either the attempted or actual commission of a rape by a slave on a female slave." ${ }^{136}$ Indeed, such a statute would never have been written for the protection of this intimate sphere belonging to a slave, simply because nothing really belonged to enslaved women under the law, including their intimate selves. The fact that such a law did not exist is not necessarily shocking then, but serves to remind us how very far the distance stretched between the law and the protection of the intimate with regard to slave women. Even the quintessential victim in the Victorian world view, the child, was a status denied to enslaved youth.

\footnotetext{
${ }^{134}$ Freedman, Redefining Rape; See also Block, "Rape Law in 19th-Century America"; See also Cott, "Marriage and Women's Citizenship"; See also Hasday, "Contest and Consent: A Legal History of Marital Rape."

${ }_{135}$ Bardaglio, "Rape and the Law in the Old South," 758-9.

${ }^{136}$ George v. State, 37 Miss. 316 (1859), 320, and Bardaglio, "Rape and the Law in the Old South," 758-9; See also Sommerville, Rape and Race in the Nineteenth-Century South, 65.
} 
In Rape and Race in the Nineteenth-Century South, historian Diane Miller Sommerville points out that the "unique status" of slave women, "as both property and human beings, problematized the issue of sexual assault." She asks, "How could property be sexually violated?"137 Based on this understanding, what is still extremely shocking about the case is not that a white Southerner declared female slaves unprotected by the law, which was nearly to be expected, but that the slave's counsel, referencing Thomas Cobb's treatise on slave law, stated: "The crime of rape does not exist in this State between African slaves. Our laws recognize no marital rights as between slaves; their sexual intercourse is left to be regulated by their owners. The regulations of law, as to the white race, on the subject of sexual intercourse, do not and cannot, for obvious reasons, apply to slaves; their intercourse is promiscuous..."138 This led the judge to agree that, "Masters and slaves cannot be governed by the same common system of laws: so different are their positions, rights, and duties." ${ }^{139}$ The judge succinctly purports that no intimate space is relegated to the ownership of the enslaved woman, and none should be, because she could not own herself in this way as a slave. It was not her "position," "right,"' or "duty."

All of these arguments, along with those made by most white Southerners, aimed to keep black slave women from having any claim to protection from rape of their white masters. What is also highly interesting about this case is that it created a precedent that

\footnotetext{
${ }^{137}$ Sommerville, Rape and Race, 64-5.

${ }^{138}$ George v. State, 317. See also Bardaglio, "Rape and the Law in the Old South," 758-9; Cobb, An Inquiry into the Law, 99-100; Finkelman, Slavery and Law, 50; Sommerville, Rape and Race, 65; See also Accomando, "The Laws were Laid Down to Me Anew," 236-7.

${ }^{139}$ George v. State, 320, and Bardaglio, "Rape and the Law in the Old South," 758-9, and Finkelman, Slavery and Law, 50.
} 
could mitigate a situation in which black slave men would avoid punishment of rape crimes against black slave women.

Historian Sharon Block has pointed out that "when the legal system defined enslaved women outside the judicial parameters of rape, there was little room for negotiation. ... A legal system that erased the social persona of enslaved women created a sexual system that elided their resistance by negating the power of their words." ${ }^{140}$ This held true in courts and in other areas of formal power and yet, we can hear in narratives the ways that storytelling and memory, resistance and self-claim all created situations where these women pushed back, creating spaces where they were contributors and power-holders.

It should be noted that, even if the statutes had allowed for the possibility of trial on rape charges in these situations, several other legal trappings would have prevented prosecution of the white men responsible for this intimate oppression.

First, a slave was not allowed to testify against a white person in court, and this law would have prohibited slave women from testifying against their rapists. ${ }^{141}$

Second, a master's "consent or intercession" would have been required in order to file criminal charges on behalf of the slave. Undoubtedly white Southerners would have gladly withheld their consent in these cases, as the accused were likely to be someone from their household, or a fellow white neighbor. ${ }^{142}$ Indeed, the only rapes that even appear in the public eye of the southern courtroom are those that involved some dramatic

\footnotetext{
${ }^{140}$ Block, "Lines of Color, Sex, and Service," 157.

${ }^{141}$ George M. Stroud, Sketch of the Laws Relating to Slavery in the Several States of the United States of America (New York: Negro Universities Press, 1968) [originally published in 1856], 38. See also Block, "Lines of Color, Sex, and Service," 142; Higginbotham, "Racial Purity and Interracial Sex," 2011, and Flanigan, "Criminal Procedure in Slave Trials," 556.

${ }^{142}$ Sommerville, Rape and Race, 64; See also Flanigan, "Criminal Procedure in Slave Trials," 556.
} 
dimension. State of Missouri v. Celia brought up the issue of slave rape, but only in the contextual trappings of a murder trial where the slave was on defense. George v. State of Mississippi was a rape case (and possibly the only of its kind to appear in history-a case of rape against a female slave), but it also involved a minor, and there was some question as to whether the child slave would be seen as a minor in the eyes of the law, or simply as a slave. The message from both cases is essentially the same. Enslaved women are property and nothing more when it comes to the law.

Third, the stereotypes of black women as inherently promiscuous would have been a moral weapon used against these women, making their claims seem weak. ${ }^{143}$ Slave women were frequently the brunt of attacks on moral worth. In George v. State the especially telling reference to slave women as "promiscuous" (even in this case in which the rape victim was a nine-year-old girl) reveals a common method of attacking bondswomen's sexual purity and defining them outside the boundaries of respectable morality. This seems to have been an effective way for Southern men to justify the commonality of interracial sex (usually forced) that occurred between Southern masters and slave women. Images like the "jezebel" image were also used to excuse "the failure of almost all jurisdictions to criminalize rape of a slave woman..." ${ }^{144}$ Using this method of over-sexualizing black women and appropriating blame, white men could remain theoretically "blameless" in any instances of "sexual debauchery," as "the supposedly

\footnotetext{
${ }^{143}$ Higginbotham, "Racial Purity and Interracial Sex," 2011.

${ }^{144}$ Finkelman, Slavery and Law, 50. See also Accomando, "The Laws Were Laid Down to Me Anew," 236-7.
} 
"debased" moral character of women of African descent was widely considered the major causative factor that encouraged promiscuity on the part of white men." ${ }^{145}$

Finally, juries of white men who decided such cases would not have been likely to convict a white man, whom they believed had a right to sexual domination in the first place. Southern whites never intended for their legal system to be used to protect slaves, and they successfully created the laws for decades to exclude them, and especially slave women, from possession of legal human rights.

It is for all of these reasons that historians have searched in vain for a true criminal rape case involving a white master and a black slave woman. Although it is obvious that rapes of black slave women occurred at this point in history, many historians claim that, at the very least between 1700 and the Civil War, a case like this does not exist. ${ }^{146}$

While slaveholders sought a strong hold over the legal and media narratives of what rape meant, why it happened, and who was in control, slaves quietly effected their own counter-reality when possible. Sometimes they withheld their bodies, or their children's bodies, from slaveholder's intimate control. Sometimes they were made to bear the rape of their bodies, no matter how they contested, but they continued to resist with their voices.

What we can hear in the voices of the ex-slaves who wrote narratives is the way that individual slaves, families, and communities all struggled to retain some of their own self-possession and cultural capitol. They tell us of rape and lust and power, but they are

\footnotetext{
${ }^{145}$ Adele Logan Alexander, Ambiguous Lives: Free Women of Color in Rural Georgia, 1789-1879 (Fayetteville: University of Arkansas Press, 1991), 64.

${ }^{146}$ Higginbotham, "Racial Purity and Interracial," 2011; See also Block, Rape and Sexual Power, 65; see also Block, "Lines of Color, Sex, and Service," 142-3.
} 
also effectively narrating an alternate story to the one that white slaveholders would have chosen to tell us about the history of rape in antebellum America. The slaves themselves turn out to be able to tell their own story, without letting their words be controlled or negated any longer, and in them we can hear about the resistance. Sometimes through reproductive choice, sometimes through mothering, and even sometimes through submission, but not to their intimidator. Harriet Jacobs admitted to her readers that she did yield herself to the will of a white man, but reminds us that she did so because the alternative was to submit to her master, who tormented her with his base desires. In this way, she effectively took control of her body by yielding it, saying that it "seems less degrading to give one's self, than to submit to compulsion. ${ }^{147}$ Celia similarly claimed the right to self-defense, perhaps more boldly and transgressively than Jacobs did, her story being harder to tell and "sell," even in the context of anti-slavery interest in such stories. After all, Celia was a murderess. Jacobs compromised her morality as pertained to her own body, severely constrained by violence and threats. ${ }^{148}$

Many of the issues that statutes, cases, and Southern attitudes have reflected thus far in this paper are also reflected in one important book from the time period. Author Thomas R. R. Cobb (previously mentioned) is referenced by judges, and at times lawyers, in almost every antebellum court case where a slave is concerned. He was considered one of the most knowledgeable men on Southern law, and thought to be especially versed on slave law. Cobb was a Southerner who supported the institution of slavery as a positive good, yet he discussed twice the possibility of rape of female slaves in his 1858 publication An Inquiry into the Law of Negro Slavery. A more thorough understanding of

${ }^{147}$ Jacobs, Incidents in the Life of a Slave Girl, 55.

${ }^{148} \mathrm{Jacobs}$, Incidents in the Life of a Slave Girl; McLaurin, Celia, A Slave. 
his words can, therefore, allow us a glimpse into the larger Southern ideology of slavery and how that affected the court decisions regarding enslaved women's sexual coercion. ${ }^{149}$ While enslaved women did sometimes claim their bodies and their right to their intimate selves, even in the face of sexual brutality and coercion, as did Celia and Harriet Jacobs, the sentiments of the slaveholding elite and southern society kept it from being easy to lawfully do so, and Cobb's work gave power and cover to lawyers, judges, and other authorities who sought a way to smooth out contradictions in slave law. ${ }^{150}$

First, in his introduction Cobb acknowledges that "an evil attributed to slavery, and frequently alluded to, is the want of chastity of the female slaves, and a corresponding immorality in the white males. To a certain extent this is true; and to the extent that the slave is under the control and subject to the order of the master, the condition of slavery is responsible." ${ }^{151}$ This leading in to the topic of slave rape seems to declare that anyone other than the white men are responsible for these "alluded to" acts of immorality. He even blames the system of slavery itself above the men, which is a slippery formulation to be sure. He then goes on to convince his readers that this culpability is actually just a rumor, claiming: "Every well-informed person at the South, however, knows that the exercise of such power for such purpose is almost unknown." 152 He proceeds by blaming the "natural lewdness" of slave women for any such occurrences, claiming that it is an inherent trait of theirs brought over from Africa. More shocking still, he attempts to claim that some slave women desire these sexual

\footnotetext{
${ }^{149}$ Accomando, "The Laws Were Laid Down to Me Anew"; See also Morris, Southern Slavery and the Law.

${ }^{150}$ McLaurin, Celia, a Slave; See also Jacobs, Incidents in the Life of a Slave Girl.

${ }_{152} \mathrm{Cobb}$, An Inquiry into the Law of Negro Slavery, ccxix.

${ }^{152}$ Ibid.
} 
relationships so that they might produce mulatto children, who enslaved women are said to understand are a superior race. After this claim Cobb says that "Under such circumstances the prevalence of this sin [of sex between the races] is not surprising." 153 As the author progresses, he seems to admit a little more that interracial sex was "prevalent," but that it must be blamed on the system, and more importantly, the black race.

In a later chapter of the book Cobb discusses rape again and, more specifically, the exclusion of slave women from legal protection. He admits that "Another consequence of slavery is, that the violation of the person of a female slave, carries with it no other punishment than the damages which the master may recover for the trespass upon his property." 154 Surprisingly, he goes on to admit that this is "suggestive of defects in our legislation," and should be reviewed. ${ }^{155}$ Lest we think that Cobb is having a relapse toward compassion, he follows with another denial, reminding his readers that "The occurrence of such an offence is almost unheard of..."156 In the end, he shows that his true priorities are not within the pondering of the legal protection of slave women, but with the "honor of the statute book," which is ultimately cited as the reason that the possible defect should be investigated. ${ }^{157}$

The generally ambiguous arguments employed by Cobb are reflective of those used by many others to justify the lack of legislative protection for slave women against

\footnotetext{
${ }^{153}$ Ibid., ccxix-ccxx.

${ }^{154}$ Cobb, An Inquiry into the Law of Negro Slavery, 99; See also Bardaglio, "Rape and the Law in the Old South," 757.

${ }^{155}$ Cobb, An Inquiry into the Law of Negro Slavery, 99.

${ }^{156}$ Ibid., 100.

${ }^{157}$ Cobb, An Inquiry into the Law of Negro Slavery, 100; for a more thorough discussion of Cobb's opinions on rape in the South, See Christina Accomando, "The Laws Were Laid Down to Me Anew," 230236.
} 
rape. As Accomando pointed out in her analysis of Cobb, his hesitancy and selfcontradictions when attempting to discuss the issue of rape were also common of Southerners, who struggled to maintain extreme rape laws against black men who attempted or did rape white women, while ignoring slave women's sexual coercion.

For my purposes, with regard to his discussion on rape law I am most interested in the ways that Cobb can be seen as representative of antebellum law makers and citizens, who found ways to talk about slave rape while not really talking about it at all. This identification of a stark abuse of power and sexual coercion by slaveholders, and then the immediate dismissal of its import, shows us a major precedent in the enforcement of white supremacy. This precedent would continue to perpetuate the long time disadvantaging of African Americans in the U.S. within the justice system, which is still prevalent today. ${ }^{158}$ One of the decisive components of supremacist thought is this method of covering up fault while leaving space for contradiction for those in control, and meanwhile, employing highly strict regulation of 'the other.' In other words, for Cobb, enslaved women were always predetermined to be amoral, and therefore, at fault, but white historical actors were understood to be morally complex and ultimately given the benefit of the doubt whenever necessary.

Unlike the handling of rape with regards to black women, scholars generally concur that "rape or attempted rape of a white woman by a bondsman demanded especially fierce retribution because it challenged slavery and the racial order of southern society." "This can be understood to mean that rape of a black woman did not challenge

\footnotetext{
${ }^{158}$ Khalil Gibran Muhammad, The Condemnation of Blackness: Race, Crime, and the Making of Modern Urban America (Cambridge: Harvard University Press, 2011).

${ }^{159}$ Bardaglio, "Rape and the Law in the Old South," 755.
} 
the status quo. It did the opposite of challenge it. Sexual exploitation of black women perpetuated the violent domination that white men had over their bodies, and punishing these men for acts or rape would have openly challenged the racial order, and the system of slavery itself.

The inequality of sentencing played out in case after case involving alleged rape of a white woman by a black man. One noteworthy example, connected to our analysis of rape law, is the 1852 Georgia Supreme Court case Stephen v. State. This case was similar to George v. State in many ways. It too involved an appeal on behalf of a slave man, this time named Stephen, and it also involved attempted rape of a minor. The difference, which literally meant death for Stephen, was that the minor in this case was defined as legally white. ${ }^{160}$

While language from George v. State had served to condemn slave women (and even the nine year-old-victim) for supposed promiscuity, language in this case would uphold the purity and "inherently virtuous" white female. ${ }^{161}$ Delivering his opinion, Judge J. Lumpkin claimed that he would attempt to "dispassionately" investigate the case, but that "The crime, from the very nature of it, is calculated to excite indignation in every heart; and when perpetrated by a slave on a free white female of immature mind and body, that indignation becomes greater, and is more difficult to repress." 162 This statement, implying that the rape of a white female was more difficult to repress than that of a black female would have been, is highly charged with white superiority. Lumpkin

\footnotetext{
${ }^{160}$ Accomando, "The Laws Were Laid Down to Me Anew," 230; See also Bardaglio, "Rape and the Law in the Old South," 749-51.

${ }^{161}$ Accomando, "The Laws Were Laid Down to Me Anew," 230; See also Stephen v. State, 11 Ga. 225 (1852).

${ }^{162}$ Stephen v. State, 11 Ga. 225 (1852), 230.
} 
gives the impression that "the indignation arises not from the crime of rape, but from the idea of rape against "free white" females." 163 As rape of a white woman by a black man was a capital crime, Stephen was executed for his actions. Meanwhile, white men continued their brutal physical and sexual claiming of bondswomen's bodies, unabated by law. ${ }^{164}$

The fact that the laws of antebellum Southern states did not recognize rape of enslaved women as punishable has now become clear. ${ }^{165}$ This fact seems lamented by many who lived in antebellum America; especially in the cases of abolitionists and black women. Abolitionist William Goodell argued that it is "undeniable" that "forced concubinage of slave women" occurred. ${ }^{166}$

Although enslaved women's voices are few and far between from history of this time, being barred from the official record, there is in some records a counternarrative of the meaning of intimacy and power relations around it, if certain kinds of evidence are read closely for it. While we must read between the lines with some records, other women found ways to share their counternarratives.

Ex-slave Harriet Jacobs was one such woman and her own autobiography, first published as a fictional account and later reclaimed as truth hidden by necessity, offers a rare glimpse into the psyche of a slave woman living within these contradictory legal trappings and the ways in which, however imperfectly, she restructured a space-an intimate sort of space in the attic of her grandmother's home in order to restage and

${ }^{163}$ Accomando, "The Laws Were Laid Down to Me Anew," 230.

${ }^{164}$ For an extensive list of cases involving black men executed for the attempted rape of white women, see Bardaglio, "Rape and the Law in the Old South."

${ }^{165}$ Block, "Lines of Color, Sex, and Service," 157; See also Higginbotham, "Racial Purity and Interracial Sex," 1966 \& 2011. See also Bardaglio, "Rape and the Law in the Old South," 756-7, and Alexander, Ambiguous Lives, 64-5.

${ }^{166}$ Goodell, The American slave code in theory and practice, 86. 
reclaim her moral authority as a mother over the domain of the intimate: her children. In an ironic gesture, which could be seen as hard to 'read' and value in dominant society, Jacobs had to leave her children in order to recoup the power necessary to actually mother them, and eventually to free them. This is the key counternarrative that her text offers, and its echoes can be found in other sources neglected by historians- especially in oral history.

Early on in her accounting of life as a slave girl, Jacobs admits to the torment that was inflicted upon her mind by her master, beginning at the age of fifteen. She says, "He tried his utmost to corrupt the pure principles my grandmother had instilled." It seems that she fought to resist, although she felt her status made this futile. She lamented, "but he was my master. ... He told me I was his property; that I must be subject to his will in all things. My soul revolted... But where could I turn for protection? No matter whether the slave girl be as black as ebony or as fair as her mistress. In either case, there is no shadow of law to protect her from insult, from violence, or even from death... [emphasis added]."167

After bringing two children into the world, Jacobs felt forced to escape her servitude and formulated a plan to take control of her body and life, and those of her children. With the help of some family members, a secret garret was devised in the attic of her grandmother's shed, and she took refuge there for seven long years. Jacobs's references to her "loophole of retreat," which was literally a one-inch by one-inch opening in the wall of the tiny hiding space, provide a figurative representation of the small pieces of freedom that she was able to find within her constraints of slavery. This

\footnotetext{
${ }^{167}$ Jacobs, Incidents in the Life of a Slave Girl, 27. See also Accomando, "The Laws Were Laid Down to Me Anew," 54, and Bardaglio, "Rape and the Law in the Old South," 758.
} 
piece of her narrative reveals to her readers a literal and symbolic reality in which she precariously balanced and constantly re-negotiated the control over her most intimate spaces—-her body and her children's bodies. ${ }^{168}$ Jacobs and her family quite literally created a space where there was no space, which is a parallel to the way that she created a method of control over her intimate self, where she had not been given any control.

While she secreted herself away in a nine foot by seven foot space (only three feet high at its tallest point), barely large enough to sit up in and torturous on her body and mind, she understood that she was choosing a confinement, not being confined by a tyrannical master. ${ }^{169}$ She was controlling her body and her mind, even if the result was sometimes depression and often times pain and physical ailments brought on from the stress of lying in a cramped space for such a long time. Just as she had chosen to give her body in a consensual relationship with a white man instead of submitting to the demands of coercion from her owner, she chose the small attic space and the suffering that it brought over the comfortable but controlled environment of the cabin that her owner tried to keep her in. ${ }^{170}$ During her time in the attic she also successfully gained some control over the bodies of her children, who her owner had so often tormented and threatened her with (by arranging their sale to their father, and emancipation soon after). ${ }^{171}$

As Jacobs reveals, enslaved women were thoroughly aware that the Southern legal system sought to deny them their rights, and they also comprehended what that meant for their ability to protect their virtue, and their bodies. While some slave women resisted their masters' advances, as Jacobs did, many could not, and were forcibly made

\footnotetext{
${ }^{168}$ Jacobs, Incidents in the Life of a Slave Girl, 114-117.

${ }^{169}$ Ibid., 114.

${ }^{170}$ Ibid., 53-57.

${ }^{171}$ Ibid., 126-138.
} 
to submit their bodies to their tormentors. As Sharon Block pointed out, "Under a master's power, rape became sex, resistance became consent, and women's desires and pains became irrelevant." ${ }^{172}$ Many roadblocks kept these violent bodily offenses from ever reaching justice. In the case of Harriet Jacobs, in the end, she resorted to imprisoning herself in order to escape her tormentor, putting an ironic spin on a world slavery turned upside down. ${ }^{173}$

In the system of subjugation that was Southern slavery, enslaved women found it necessary to find alternate means to guard, control, and protect their most intimate spaces. While discussion about slave rape in the legal community was highly superficial, some enslaved women found their most intimate spaces made public in the courtrooms. Ultimately, the antebellum legal system left them uniquely vulnerable to sexual coercion and rape, and the employment of the Roman law partus sequitur ventrem left them susceptible to reproductive exploitation as well. These legal trappings created a space where enslaved women could be legally raped, without recourse against the white men who perpetrated the acts. In direct contrast, white women were protected from rape of black men by laws that allowed severely brutal punishment, including death, even for attempted rape.

These inequitable rape laws offer historians a look at the racial hierarchy that was the antebellum South, and explain how intimate oppressions were perpetuated, creating a precedent for the judicial exploitation of black men and women that continues today. While regulations set forth regarding rape aided in leaving ultimate physical control over

${ }_{173}^{172}$ Block "Lines of Color, Sex, and Service," 158.

${ }^{173}$ Ibid., 141. 
enslaved women's bodies in the hands of their white owners, these women were able to find other ways to claim control over their bodies. And they did. 


\section{Chapter 3}

When they claimed themselves:

Bondswomen's Resistance \& Self-Ownership Through Reproductive Choice

For those who encounter oppression through the body, the body becomes an important site not only of suffering but also ... resistance.

$$
\text { Stephanie M. H. Camp (2004) })^{174}
$$

I would do any thing, every thing, for the sake of defeating him.

My master had power and law on his side; I had determined will. There is might in each.

$$
\text { Harriet Jacobs (1857) }{ }^{175}
$$

While it is ultimately true that enslaved women were legally and physically claimed by others, it is crucial that we also recognize the numerous ways that they then claimed themselves. Who is to say which method of ownership, which persons claim, matters most? This point to define what is most important, most valuable, or least so, is a crucial way in which power inequalities have been maintained over time. This chapter seeks to highlight the "subjugated knowledge" of black people, especially black women, in contesting the highly unequal relations around the intimate. Ironically, the intimate can be a domain most accessible to the individual in terms of how it is experienced, narrated, and remembered, even as it was certainly regulated by powerful entities and people, as shown in the preceding chapter.

\footnotetext{
${ }^{174}$ Stephanie M. H. Camp, Closer to Freedom, 62.

${ }^{175}$ Harriet Jacobs, Incidents in the Life of a Slave Girl, 53, 85.
} 
While Harriet Jacobs admits to the distress that her master's advances brought on, she also shows us a strength in her defiance, at age fifteen, to use any means possible to keep him from winning his quest to steal her virtue and compel her to submit sexually to him. She "would do any thing, every thing, for the sake of defeating him." ${ }^{176}$ In her narrative, Incidents in the Life of a Slave Girl, Jacobs tells readers how it began so often with young slave women and their masters. "I now entered my fifteenth year-a sad epoch in the life of a slave girl. My master began to whisper foul words in my ear. Young as I was, I could not remain ignorant of their import... I turned from him with disgust and hatred. But he was my master... He told me I was his property; that I must be subject to his will in all things. My soul revolted against the mean tyranny."177

And yet. She did not submit. She told Dr. Norcom (her owner) "you have no right to do as you like with me!" ${ }^{178}$ She felt that she was the master of her body and even though, in the end, she felt it necessary to share her body with another white man, she still rightly claimed this as victory saying, "It seems less degrading to give one's self, than to submit to compulsion. It was something to triumph over my tyrant even in that small way." ${ }^{179}$ She had successfully made the choice of who she would share herself with, and her 'owner' had not been able to force her to play concubine to him. He had lost and she had won the battle over physical claim on her young body, at least in this way. ${ }^{180}$

\footnotetext{
176 Ibid., 53.

177 Ibid., 27.

178 Ibid., 39.

${ }^{179}$ Ibid., 55.

${ }^{180}$ Granted, this story ended with the heroine as victorious in part because Jacobs's owner was a prominent figure in his community and wanted not to be called out for lying with his slave women. Many men wouldn't have cared and would have tried to force her to submit with physical brutality. Jacobs herself explained how sexual coercion normally worked with the slaves she had known, "When she is fourteen or fifteen, her owner, or his sons, or the overseer, or perhaps all of them, begin to bribe her with presents. If
} 
While slaveholders held titles granting them ownership, men forcibly used their bodies to physically and brutally stake claim to what they felt they owned, and laws and courtrooms made these methods of domination 'lawful,' enslaved women did not sit idly by. They also chose to claim themselves, recognizing that they were additional players on the stage of slavery, and that they could own too, even if it was often in quieter, more private ways, or in a manner that laid claim to the bodies of their children.

In exploring bondswomen's claims on their own bodies, we can not help but find also their resistance to slavery. Female slaves' rebellious reproductive decisions, carried out sometimes by simply refusing to be used sexually coerced or used as a breeder, and other times through extreme methods like abortion and infanticide, can and should be analyzed as resistance against slaveholders' particular methods of slave breeding, as well as against the 'rules' that society and their masters made for them, and therefore against the system of slavery and oppression itself.

The legal permission to rape female slaves in antebellum America created a space where institutionalized rape, carried out in part with the commodification of bondswomen as breeders, resulted in specific kinds of resistance through reproductive choice. Enslaved women who participated in resistance through reproductive choice were rejecting the conditions in which their subjugation placed them. They refused to allow their intimate selves to be wholly dominated and used what resources they had to defy their system of oppression. Infanticide was the most dramatic act of resistance, and the mothers who chose to commit this act seem to have done so in order to keep their child from ever knowing a world where their most intimate selves would be essentially unprotected, 
claimed, and tortured. The mothers who murdered their children in order to keep them from suffering under slavery were not heartless, they were desperate. In some cases the infanticide was committed against a product of rape, but there is no indication that the mothers abhorred the children who came from these violent acts of sexual coercion. They did not lose their ability to mother based on the role of the biological father, and they understood that even a child of a white man was a slave, and therefore guaranteed no protection or latitude from society. Abortion was an act of resistance that was likely more common, although it's secretive nature makes this hard to 'prove,' yet the discursive nature of these acts makes their rebelliousness more apparent. Ultimately, historians will need to apply a nuanced definition of resistance to these gendered methods of opposition if we are to interrupt the tradition of narrating the powerful as 'the story' in history. I argue that enslaved women should be recognized as agents and owners of their own bodies.

It has historically been easy for the gendered aspects of resistance to be overlooked. Most would agree that women did resist, but their resistance was often less obvious than masculine modes like revolts, attacks, or escapes. It is possible that the very instability of bondswomen's responses to their legal non-being is an indictment of the system itself. When seemingly attempting to untangle a definition of enslaved women, Stephanie Camp says that "they were both agents and subjects, persons and property, and people who resisted and who accommodated-sometimes in one and the same act. Enslaved people were many things at once, and they were many things at different moments and in various places. They lived multiple lives, some visible to their owners 
and to the archival record, some less visible." ${ }^{181}$ She succeeds in illuminating the truth as she likely intended to-enslaved women lived in an ambiguous space and played many parts. This complication is what makes them so interesting and multi-dimensional, and what makes them so illusive to pin down in record at times as well. It could be understood that their bodies were also 'many things at different moments and in various places.' Slave women existed as property, breeders, mothers, laborers, wives, sexual temptations, victims of lust and greed and hate, and also as agents and willful claimants of themselves. This last role might be overlooked most often.

Still, some historians have built up conversation on how slave women's bodies were used as a tool of resistance, and this work has been key to my own ideation. In 1942, long before many historians were paying much attention to enslaved women (let alone their gendered history) in their research, Alice and Raymond Bauer published the article "Day to Day Resistance to Slavery." Although they have some masculinist ideas about what constitutes resistance and who a slave is (male), I am struck by their inclusion of infanticide in their discussion of resistance. The Bauers are not quite certain what to make of infanticide as resistance and a debate on how to interpret these acts does not appear. However, the authors were keenly aware at this early year that this was a pattern of resistance that should be studied further and they add that, "occasionally one runs across a reference to a slave mother killing her child, but statements are almost invariably incomplete" when researching these acts. ${ }^{182}$ Such evidence enters into sources considered

\footnotetext{
${ }^{181}$ Camp, Closer to Freedom, 1-2.

${ }^{182}$ Raymond A. Bauer and Alice H. Bauer, "Day to Day Resistance to Slavery," The Journal of Negro History (1942), 388-419.
} 
solid proof in an incomplete, fragmentary manner, placing heavy demands on interpretation.

Angela Davis and Deborah Gray White, who could be seen as revisionist historians of their time, were among the first to focus on the subject of reproductive choice. While they had contrasting opinions on the commonality of abortion and infanticide, both researchers found them to be valid forms of resistance carried out by slave women who claimed agency for themselves through their bodies.

In fact, Davis was inclined to value women's agency as heroic, highly conscious, and directed at the mode of production. She stressed that the system of slavery relied upon "natural reproduction," and she highlights how this practice undermined slaves' natural roles as mothers, demeaning them to the function of breeders. ${ }^{183}$ Since slaveholders felt entitled to use their slave women's bodies as they wished, they chose at times to demand that they be used to produce more wealth in the form of offspring, whose bodies they would then immediately lay claim to as well. ${ }^{184}$ It was this form of oppression (slave breeding) then, specific to slave women, that would create the opportunity for their unique methods of resistance.

Davis points out that "black women have been aborting themselves since the beginning of slavery" due to their refusal "to bring children into a world of interminable forced labor, where chains and floggings and sexual abuse for women were the everyday

\footnotetext{
${ }^{183}$ Davis, Women, Race, and Class, 6-7.

${ }^{184}$ Deborah Gray White provides a parallel argument about the ways that female slaves were used as breeders in a system of domestic reproduction prevalent during the time period, and she links this to how slave men and women did not experience slavery in the same way, and therefore sometimes resisted in distinctive ways. White, Ar'n't I a Woman?, 62-3.
} 
conditions of life." ${ }^{\prime 185}$ When discussing infanticide she utilizes the story of Margaret

Garner-a runaway slave, and a mother who was sent to trial for killing her young

daughter instead of allowing her to be taken back to slavery. ${ }^{186}$ Davis leaves Margaret

Garner to be her reader's emblem and symbol of infanticide, declaring that some women,

"were driven to defend their children by their passionate abhorrence of slavery.", 187

White employs more methodological caution to her assumptions, carefully

pointing out that acts of infanticide represented "atypical behaviors on the part of slave

mothers," and she even suggests that many accusations of infanticide could actually be

"smothering" deaths that we would now recognize as Sudden Infant Death Syndrome

(SIDS). ${ }^{188}$ These cautions result in a divergent conclusion from Davis about how

common acts of infanticide and abortion really were, but not that they existed. ${ }^{189}$ The

\footnotetext{
185 Davis, Women, Race, and Class, 204.

${ }^{186}$ Davis, Women, Race, and Class, 21; See also Weisenburger, Modern Medea.

${ }^{187}$ Davis, Women, Race, \& Class, 21-29 \& 205. Davis' purpose seems to be provocation; to shock her reader out of their assumptions about black women's passivity and silent victimization as slaves. She uses some powerful rhetorical questions, like: "why were self-imposed abortions and reluctant acts of infanticide such common occurrences during slavery?" She purports that they were "acts of desperation, motivated... by the oppressive conditions of slavery."

${ }^{188}$ White, Ar'n't I a Woman?, 87-89. While White is careful to say that infanticide was not common and that some of the stories told of them could have been from SIDS, she still lists 4 cases of infanticide committed by slave mothers where SIDS could not be the cause of death, and two of these cases clearly reflect the fact that the mothers killed their children to save them from suffering the life of a slave. For more information on the theory that Sudden Infant Death Syndrome (SIDS) was responsible for a majority of "rolling over" or "smothering" deaths wrongfully accused on slave mothers during the history of slavery see Michael P. Johnson, "Smothered Slave Infants: Were Slave Mothers at Fault?," The Journal of Southern History (1981), 493-520. See also Richard H. Steckel, "Women, Work, and Health under Plantation Slavery in the United States," in More Than Chattel, ed. David Barry Gaspar and Darlene Clark Hine (Bloomington: Indiana University Press, 1996), 43-60, and King, "Suffer with Them Till Death," 147168 .

${ }^{189}$ White notes that, observers at the time believed that slaves were using abortion to keep from producing viable children for the system, and she provides reasons why slaves would wish to prevent bringing children into such a cruel world; like the desire to deny their white masters "the satisfaction of realizing a profit on the birth of their children" 189 Yet, she further admits that "it is almost impossible to determine whether slave women practiced birth control and abortion. These matters were virtually exclusive to the female world of the quarters, and when they arose they were attended to in secret and were intended to remain secret." White, Ar'n't I a Woman, 84-86.
} 
authors are in agreement on their existence within the quieter corners of slave history, and that these acts are at least plausibly understood as methods of resistance.

White and Gray are crucial early framers of the question of reproductive choice and behavior. Either due to the unavailability of cases, or due to the difficulty in interpreting them, many scholars who have discussed resistance have left infanticide and abortion alone.

Taking a slightly different approach, Stephanie Camp has contributed a great deal to the conversation about enslaved women's resistance, especially through specific methods involving their use of their physical body. She argues that "enslaved people's everyday battles for "regaining" a measure of "control" took place on very "personal" terrain; their bodies." 190 Though she is not concerned specifically with reproductive matters, Camp offers some rich theories about the concept of "everyday resistance," which aid us in the framing of those methods of resistance that I am focused on. She argues that "for bondswomen, even more than for enslaved men, intimate entities, such as the body and the home, were instruments of both domination and resistance." ${ }^{191}$ This theory supports my evolving sense of female slave resistance through abortion and infanticide.

In More Than Chattel: Black Women and Slavery in the Americas, Editors David Barry Gaspar and Darlene Clark Hine provide a transnational discussion on black women and resistance, with some focus on reproductive choice. Articles pointing to female slave

${ }^{190}$ Camp, Closer to Freedom, 62.

191 Ibid., 3 \& 6. 
abortion and infanticide cite evidence from doctors, planters, religious leaders, and slave midwives to support their claims. ${ }^{192}$

Wilma King devotes some consideration to the breeding of slaves and the possibility of infanticide and abortion among those populations, but she falls far short from taking a side on how important these acts could have been if considered as resistance to the system of slavery. Her arguments about breeding and acts of infanticide are ambivalent. In regards to breeding, she says that "American slaveholders viewed motherhood as an asset, and they encouraged reproduction for pecuniary reasons alone." ${ }^{193}$ She claims that "some women took more drastic steps to undermine reproduction by refusing to conceive children or by aborting them." ${ }^{194}$ Evaluating infanticide as "appropriate" is not my intention here; rather it is to highlight the difficulty of evaluating behaviors which themselves are fugitive in nature and documentation. The gathering up of this scattered resistance is important work though, as it enables us to create an oral tradition that recognizes the proof of women's survival and integrity under slavery.

In Soul by Soul, Walter Johnson's provocative historical discussion of the slave markets of New Orleans, the author offers us meticulously researched instances when women's reproductive abilities were on center stage in the markets and auction houses. This includes descriptions of how slaveholders sometimes made their choices on slave

\footnotetext{
${ }^{192}$ While many of these instances were outside of my geographical boundary, the ability to confirm these acts does lend some validation on the happening in the U.S. as well. Gaspar and Hine, More Than Chattel. ${ }^{193}$ King, "Suffer with Them Till Death," 147-8.

${ }^{194}$ King only appears to flag smothering deaths and their probability to actually have been cases of SIDS, and she discusses these as instances when mothers were accused of infanticide. However, in the end she supposes that it was simply easier for whites to accuse slave women of infanticide than it would have been to understand why the infant mortality rates were so high, and she clarifies that she does not want to deny the documented reports of infanticide that do exist. ${ }^{194}$ King, "Suffer With Them Till Death," 159-160. 
purchase based on the hope of returning a profit from a black slave woman's childbearing abilities. ${ }^{195}$ As Johnson describes the market he says that buyers compared women physically; "they palpated breasts and abdomens, searching for hernias and prolapsed organs and trying to massage bodies into revealing their reproductive history." Johnson argues that "buyers were concerned that their female slaves be 'breeders." 196

In affirming that slave women's reproductive choices should be read as resistance an explanation of their place within the system of slavery opens up interpretation in a number of directions. Black slave women in the antebellum United States were highly valued as a commodified bio-power, in this case reproductive power, and enslaved women responded to this in a number of ways. White purports that "once slaveholders realized that the reproductive function of the female slave could yield a profit, the manipulation of procreative sexual relations became an integral part of the sexual exploitation of female slaves."197 They were exploited to contribute to the very system that oppressed them.

In Charles Parsons's journal published in 1855 as Inside View of Slavery; or, A Tour Among the Planters, Parsons frankly writes, "The term slave has a definite meaning. It signifies, not a person, but a thing, a chattel..."198 For everyone involved in the system of slavery this meant that "a slave child was property; its birth added to a slaveholder's coffers regardless of the conditions under which it was conceived." ${ }^{199}$ Due to the desire to

\footnotetext{
195 Johnson, Soul by Soul, 83-144.

196 Ibid., 143-144.

${ }^{197}$ White, Ar'n't I a Woman?, 68.

${ }^{198}$ Parsons, An Inside View of Slavery, 54.

${ }^{199}$ King, "Suffer with Them Till Death," 159.
} 
continue reproduction of their chattel, some masters aimed to breed their slaves as often as possible, therefore, yielding the most profit (or capital) as was possible over time.

It is well documented that slave women for sale often went listed with important information regarding their breeding or reproductive quality, and that slaveholders looking to expand their slave population would often pay extra attention to the bodies of the slave women they saw at auction. ${ }^{200}$ Many times slaves were even explicitly listed as breeders if they were young and able to bear many children. ${ }^{201}$ Furthermore, much public attention was given to black slave women's reproductive abilities. For example, White says that "major periodicals carried articles detailing optimal conditions under which bonded women were known to reproduce, and the merits of a particular 'breeder' were often the topic of parlor or dinner table conversations."202

Hannah Jones, an ex-slave from Missouri who contributed to the Works Progress Administration slave narratives specifically remembered how the system of breeding looked where she grew up a slave. She described how "the niggers had three or four wifes before de war, as many as dey could bear chillun by." ${ }^{, 203}$ She continues this theme of reproduction as central when she says that the doctor told her grandmother's master that "she's stone blind, but she can have chillun right on," and her master "kept her for dat and she bore twelve more head of chillun after dat." 204 Jones also states that "when dey want to raise certain kind a breed of chillun or certain color, dey just mixed us up to suit dat taste, and tell de nigger dis is your wife or dis is your husband and dey take each

\footnotetext{
${ }^{200}$ Johnson, Soul by Soul, 83-144.

${ }^{201}$ Erlene Stetson, "Studying Slavery: Some Literary and Pedagogical Considerations on the Black Female Slave," in All the Women Are White, All the Blacks are Men, But Some of Us Are Brave, eds. Gloria T. Hull, Patricia Bell Scott, and Barbara Smith (New York: The Feminist Press, 1982), 74.

${ }^{202}$ White, Ar'n't I a Woman, 31.

${ }^{203}$ WPA Slave Narrative Project, "Hannah Jones," Missouri Narratives, Vol. 10 (1936-1938), 214.

${ }^{204}$ Ibid. 215.
} 
other... and raise big families to de white folks liking." ${ }^{205}$ In other words, historians have given scant attention to the ways in which "breeding" institutionalized enslaved and free sexual and reproductive access to enslaved women. Of course, expectations could be variously enforced on enslaved men, including coercion and punishment and shaming. However, one former slave's account hinted at pressure to marry, which could lead to early serial monogamy in slave communities. Interestingly, Jones' discussion of pressure to "breed" from the planters point of view is countered by a story of many "wifes" in the slave community. She also hints at the notion that enslaved men might be demonstrating or proving their fertility as part of the bio-economy of enslavement, a question not yet pursued by historians. This situation would clearly suggest that a breeding system was in place, and it further hints to how valuable the ability to 'breed' was, and yet also how unstable in its meanings.

Indeed, there are hints about pressures on enslaved women and men to deploy their reproductive capacity at the behest of their owners. Ex-slave Rose Williams remembered how she was purchased under the description of a "portly, strong wench," who would "make the good breeder." 206 On the new plantation she was sent at age sixteen to live with a slave man named Rufus whom she did not like. When she asked her mistress why she was to live with him she was told, "you am the portly gal, and Rufus am the portly man. The massa wants you-uns for to bring forth portly children." After continuing refusal of the situation, her master told Williams, "woman, I's pay big money for you, and I's done that for the cause I wants you to raise me childrens. I's put you with Rufus for that purpose. Now, if you doesn't want whipping at the stake, you do what I

\footnotetext{
${ }^{205}$ Ibid., 216.

${ }^{206}$ Botkin, Lay My Burden Down, 160.
} 
wants." ${ }^{207}$ In the end Williams obliged her master and reproduced with Rufus. Likely this choice had to do with the threat of being beaten. Rose never did reconcile herself to her pairing with Rufus, and when they were emancipated she separated from him and never legally married. ${ }^{208}$

Hilliard Yellerday, an ex-slave from North Carolina relates what she knew of slave breeding during her WPA interview, saying that, "Master would sometimes go and get a large hale hearty Negro man from some other plantation to go to his Negro women. He would ask the other master to let this man come over to his place to go to [breed with] his slave girls. A slave girl was expected to have children as soon as she became a woman. Some of them had children at the age of twelve and thirteen years old. Negro men six feet tall went to some of these children." ${ }^{209}$ By characterizing the females involved as "children," Yellerday draws our attention to the unfairness and inequality of a system that would allow forced "breeding" between a man "six feet tall" and "children." Hilliard's scenario is even less likely to be normalized into a functional and legitimate familial situation than Rose Williams or Hannah Jones, who at least mention slave 'marriage' as a part of the arrangement in the breeding system that they experienced. ${ }^{210}$

It has been commonly agreed upon in slavery literature that slaves were indeed viewed as chattel, and that breeding was a fairly common method of increasing or maintaining a slaveholder's capital. The fact that black slave women were labeled as breeders makes their reproductive choices highly political and important, but clearly male

\footnotetext{
${ }^{207}$ Ibid., 161-2.

${ }^{208}$ WPA Slave Narrative Project, "Rose Williams," Texas Narratives, Vol. XVI, Part IV (1936-1938), 174.

${ }^{209}$ WPA Slave Narrative Project, "Hilliard Yellerday," North Carolina Narratives, Vol. XI, Part II (19361938), 434.

${ }^{210}$ Ibid.
} 
bio-power was also seen as a part of their productive capacity in the plantation economy.

As Davis argued; "Since slave women were classified as "breeders" as opposed to "mothers," their infant children could be sold away from them like calves from cows."211 The narratives evidently contain an alternative vocabulary for valuing this system; enslaved men took serial "wives" (not breeders) and coerced young women were highly exploited and victimized "children" (not adults performing extremely unfortunate reproductive labor). ${ }^{212}$ The continuation of a degrading breeding system within the already cruel and oppressive system of slavery came with repercussions. As Camp has emphasized, "those who encounter oppression through the body, the body becomes an important site not only of suffering but also ... resistance." ${ }^{213}$

Black women living as southern slaves encountered great oppression, exploitation, and violence on their bodies. The shifting vocabularies of family roles also points us to revaluations of the body itself, its treatment and handling. Upon reviewing this material, it seems important to consider how these slave women sometimes chose abortion to challenge the demands made on them by the patriarchal white society, and system of slavery. The acts of infanticide that played out on the bodies of their small children are also connected to this theory. Given the intense medical scrutiny of abortion among free white women in the urban north in these same antebellum decades, it's important to view abortion broadly in this time period, as something that touched a particular set of anxieties and concerns over the power of female agency in general and

\footnotetext{
${ }^{211}$ Davis, Women, Race, \& Class, 7.

${ }^{212}$ WPA Slave Narrative Project, "Hilliard Yellerday, 434.

${ }^{213}$ Camp, Enslaved Women and Everyday Resistance in the Plantation South, 62.
} 
the mothering body in particular. ${ }^{214}$ With the new women's rights campaigns of the antebellum decades, suffragists argued that women turned to abortion because men dominated and mistreated their bodies and intimate space. As racial dominance and, therefore, Anglo-Saxon reproduction became a concern of white physicians and other whites, abortion was increasingly seen as a direct affront, bringing reproductive politics even more into the spotlight, and not only with regard to slavery. ${ }^{215}$

Because of slave women's roles as reproducers of property and capital in the system of slavery, any successful efforts that they made to curb reproduction meant a loss of capital for their master, and a loss of population for the system itself. In this most basic sense, any reproductive choices that slave women made could affect their system of oppression and, therefore, could rightly be read as resistance to slavery. Both abortion and infanticide were defiant acts given what we know about the procreative expectations placed on slave women in the antebellum U.S. south. Whether or not this reproductive resistance to slavery affected the system on a massive scale is not relevant in the considerations of qualifying it as resistance. Control of their children's lives through claiming and then ending that life was certainly read by antislavery advocates as an act of resistance, however desperate and terrible. Analyzing the newspapers of Cincinnati, Ohio in the days following the infanticide committed by fugitive slave Margaret Garner, we can clearly see that those papers who aligned themselves with the antislavery cause reported the act as one of resistance against a cruel and inhumane system, while the

\footnotetext{
${ }^{214}$ Leslie L. Raegan, When Abortion Was a Crime: Women, Medicine, and Law in the United States, 18671973 (Berkeley: University of California Press, 1997); See also Abortion in Nineteenth Century America (New York: Arno Press, 1974), and Tamara Kay and Nicola Beisel, "Abortion, Race, and Gender in Nineteenth-Century America," American Sociological Review, Vol. 69, No. 4 (2004), 498-518.

${ }^{215}$ Kay and Beisel, "Abortion, Race, and Gender in Nineteenth-Century America," 514.
} 
newspapers who aligned themselves with pro-slavers told of the act as a heinous crime, committed by a heartless monster. ${ }^{216}$

Camp validates "everyday resistance" in her research and claims that these everyday acts of resistance should not be devalued or seen as trivial acts. She defines everyday forms of resistance as "hidden or indirect expressions of dissent, quiet ways of reclaiming a measure of control over goods, time, or parts of one's life," and asserts that they could indeed affect the system of slavery. ${ }^{217}$ If acts that could be seen as everyday can be qualified as resistance, who is qualified to deem insubordinate acts of reproductive choice unfitting for this designation $?^{218}$ This thesis emphasizes the importance of interpreting these very words and gestures, both in the 19th century and in our own time, to support the construction of a valid memory of resistance through oral tradition. Indeed, the meaning of slavery historically is inextricable from the stories that we tell about it.

While some would argue that infanticide and abortion could be valued as expressions of oppression; in other words, that these acts were carried out only in response to the oppressive living conditions of the system of slavery itself; I disagree. If

\footnotetext{
${ }^{216}$ The Cincinnati Enquirer, “A Stampede of Slaves: A Tale of Horror,” January 29, 1856. See also Cincinnati Gazette, "Arrest of Fugitive Slaves: A Slave Mother Murders her Child rather than see it Returned to Slavery," January 29, 1856.

${ }^{217}$ Camp, Closer to Freedom, 2.

${ }^{218}$ Historian Herbert Aptheker seemed to take on this task when he published an article titled "American Negro Slave Revolts" in 1937. Aptheker argues that "the persistent and desperate struggles of the American Negro against slavery took eight forms, none of which have received anything like the treatment they deserve: (1) The purchase of freedom; (2) strikes; (3) sabotage; (4) suicide and self-mutilation; (5) flight...; (6) enlistment in federal forces...; (7) anti-slavery agitation...; (8) revolts." These acts are not only masculinist in nature, but the listing of them as the eight forms of resistance completely ignores methods of female resistance to slavery; namely resistance through reproductive choice. While I was not surprised that literature from 1937 would have ignored women's struggles to resist, I found that this list could still be useful in my own creation of a definition of resistance. Aptheker has given us a model of what male centered resistance looks like, and we can utilize this in our understanding of what constitutes female centered resistance. Aptheker, American Negro Slave Revolts.
} 
slave mothers made a reproductive choice based on their own motives and experiences, and unintentionally, negatively affected the reproductive system of breeding meant to continue the oppressive system, then I judge this still resistance. A comparison can easily be taken from one of the more accepted modes of resistance: purchase of freedom. Attempting to empathize with a slave's position as a supposed piece of property within the system of slavery, would obtaining their freedom through purchase be a goal set to intentionally destruct the system? Or is it much more likely that a slave would choose to purchase their freedom explicitly for the betterment of their own lives? I would argue that it would certainly be the latter motivation. Further, if a slave is purchasing their freedom, as opposed to becoming a fugitive in the hopes of stealing it, is this not also in a sense complicit with the rules that the system has mandated? Antislavery activists struggled with these very same conundrums; they are hardly solved in our own time. For example, Lucretia Mott generated controversy in her view that Frederick Douglass was "worth more" to the antislavery cause as a slave rather than a free man. Clearly, Douglass disagreed with this view, and he pursued self-purchase. ${ }^{219}$ Enslaved families also sought self-purchase, but in some instances they chose to purchase but not free their relatives since it would have required that they leave their state, familial, social and religion networks. ${ }^{220}$ If we are to argue that slave women's reproductive choices, here discussed through abortion and infanticide, were not resistance, than we would be forced to reevaluate all currently accepted methods of resistance to slavery since there is no such thing as "pure" resistance.

\footnotetext{
${ }^{219}$ Carol Faulkner, Lucretia Mott's Heresy: Abolition and Women's Rights in Nineteenth-Century America (Philadelphia: University of Pennsylvania Press, 2011).

${ }^{220}$ Michael P. Johnson and James L. Roark, Black Masters: A Free Family of Color in the Old South (New York: W.W. Norton, 1984).
} 
The reality is that most modes of resistance to slavery valorized in media, folklore, and academic venues are masculinist in nature, and even those that were utilized by both genders seemed to have been disproportionately performed by men (excepting reproductive choice). This is because men resisted more commonly in the ways that were recorded and recognized, as Camp and others point out. It is impossible to say if men or women resisted the system of slavery more, but it appears to have been more noticeable, that is public, when it was enslaved men doing the resisting.

For example, regarding those slaves who became fugitives (escaping slavery in the south and successfully making their way to freedom in the northern, free states), a great majority were men. Between 1838 and 1860, the percentage of fugitives from North Carolina that were women was 14\%; from South Carolina, 19\%; and from Virginia and Tennessee, $9 \%$ and $12 \%$ respectively. The largest percentage of fugitive women comes out of Louisiana and yet it is still less than one third of the total fugitive population of the state for this time period $(29 \%) .{ }^{221}$ Still, of male-centric resistance methods, "flight" is still the one that would most commonly have involved women. Reproductive choice was a method of resistance that belonged to women, and created a space where they could resist their specific oppression.

As this thesis has argued, gestures, names, behaviors- and the stories slaves and former slaves told of all of these- are unstable, multifold practices that challenge the desire for neat, concise narratives with clear borders, beginning, and end. Assuming that infanticide or abortion must be placed in the sphere of resistance should not mean a

\footnotetext{
${ }^{221}$ Camp, Closer to Freedom, 36.
} 
dismissal of slave women's great maternal love for their children. Acts of infanticide and abortion, or any other reproductive choices, do not necessitate a demeaning of slave women's humanity in terms of their children and families. The truism that creates a space where slave women existed as breeders, mothers, and sometimes destroyers, is that we can not use either/or questions when defining slaves' experiences. These women were not simply mothers or destroyers, just as they were not breeders or mothers. Camp persuasively argues that "enslaved people were many things at once," so the attempted use of dichotomous choices when summing up their existence are irrelevant. "For instance," Camp adds "the ways in which they were both agents and subjects, persons and property, and people who resisted and who accommodated- sometimes in one and the same act." ${ }^{222}$ It is too large of a simplification then to say that slave women who committed acts of infanticide had no effect on the system just because "the cases represent atypical behavior on the part of slave mothers," as White reminded us. ${ }^{223}$

While abortion and infanticide may feel like acts committed only with malice, ingrained African sensibilities and accepted religious thought often indicated to enslaved women that there were distinctions between life and death that allowed for the innocent to be granted peace. As King pointed out, "many slaves came to believe that their distress would end, if not in their present life, then certainly in the afterlife." ${ }^{224}$ It's important to note that the fact that slaveholders viewed motherhood as a commodified asset and themselves coerced reproduction does not mean that slave mothers were unaffectionate

\footnotetext{
${ }^{222}$ Ibid., 1.

${ }^{223}$ White, Ar'n't I a Woman?, 87-8.

${ }^{224}$ King, "Suffer with Them Till Death," 156.
} 
with their offspring. ${ }^{225}$ They loved their children and attempted to shield them from the cruelty of the system of slavery however they thought possible. White's description of slave mother's acts of infanticide as atypical was related to the understanding of the ingrained love that they actually had for their children. ${ }^{226}$ The removal of their child (or children) from the violent and oppressive life that they lived must sometimes have seemed the only way to protect them. Some slave mothers may have supposed that they were not only saving their children from the experience of a cruel world of slavery, but that they were in essence sending them to a harmonious afterlife. Or, as Jacobs's account repeatedly stresses, enslaved mothers do the "opposite" of what is normative in the dominant culture in terms of behavior (leaving one's children for example) in order to fulfill that same expectation (to protect one's children through a self-sacrificing gesture).

Harriet Jacobs alludes to this perception when she speaks of her fleeting wishes for her children to have died when small. After she had her son, Joseph, Harriet laments: "I could never forget that he was a slave. Sometimes I wished that he might die in infancy. ... Death is better than slavery."227 Again, after giving birth to her daughter, Louisa, she says "As I held her in my arms, I thought how well it would be for her if she never waked up." ${ }^{228}$ She never acted on these thoughts, but the way she describes them does make one wonder how often slave women considered infanticide as a method of ensuring their children would not grow up under the tortuous shadow of slavery.

\footnotetext{
${ }^{225}$ Steckel, "Women, Work, and Health under Plantation Slavery in the United States," 147.

${ }^{226}$ White, Ar'n't I a Woman?, 88.

${ }^{227}$ Jacobs, Incidents in the Life of a Slave Girl, 62.

228 Ibid., 87.
} 
The question of commonality of acts of infanticide and abortion is a slippery one. Reviewing the secondary source literature, I initially assumed that primary sources containing information on specific acts of this form of resistance would be very minimal. After all, White had provided the most samples in her study from 1985, and she listed only four non-smothering deaths in cases of infanticide. For the purpose of my study I immediately dismissed acts of infanticide that could be even remotely linked to the modern assumptions regarding Sudden Infant Death Syndrome (SIDS). Cases of abortion in White's book were even fewer, with one actual account of abortion and two doctor's reports stating that they believed it did occur among slave women. The other pieces of information that she provided were focused on the probability that some kind of contraceptive or abortive was utilized by slave women to keep them from reproducing when forcibly paired with partners who they did not like under the system of breeding that slaveholders used. ${ }^{229}$ Also, I was most interested in those pieces of evidence that I could locate and analyze myself, and some of the acts that she notes were out of my reach. Furthermore, many of the other secondary sources that provided information on these forms of black female slave resistance highlighted the same one account of infanticide repeatedly, making it seem the only piece of evidence for infanticide that I would be able to track down; the case of Margaret Garner, previously mentioned. Cases of abortion were all but invisible.

However bleak this evidentiary situation may have initially looked, I soon realized that current historians are at a great advantage in their ability to locate primary sources in a new way; online. After following the faint trails that previous researchers

${ }^{229}$ White, Ar'n't I a Woman?, 84-89. 
had left for me, I was able to locate at least twelve separate acts of infanticide that have been noted, and six of those were acts that I could analyze myself in primary source materials. It is noteworthy that five of the six accounts that I was able to read in primary source material specifically say that the mother admitted to killing their children in order to save them from the brutality of slavery. In other words, they committed acts of infanticide, as I had believed, out of what seems to be love and hope for the defense of their children against a system that would be unbearable. The consistency of this kind of telling points to a pattern, a kind of recuperative narrative project, to assign alternative meanings to gestures despised in the dominant culture for the sake of registering protest and preserving some moral autonomy in a suffocating and oppressive structure.

I was also able to locate seven pieces of evidence regarding the use of abortion among female slaves. Although these are more ambiguous in relation to cause, I would have expected this considering the complex realities that birthing in the nineteenth century encompassed. Therefore, I will not be attempting to claim that abortion was an act of defense for their unborn children, although I personally subscribe to this theory. I would speculate that more often than not these women, too, were interested in defending their offspring from a life that they found nearly unbearable. And indeed, the consistency of the narrations around this particular behavior is vitally important. Of the seven cases that I located regarding abortion, four of these are primary source materials, and three of those appear to be strong evidence for the existence of abortion among female slave populations (one of these three being a medical source record listing a plantation doctor's opinion on the matter). It would seem that in order to draw conclusions from the evidence 
that I located a detailed account of each piece would be advantageous. I will begin with acts of infanticide that I was able to corroborate through primary sources.

By far the most told and retold story of female slave infanticide is that of Margaret Garner. ${ }^{230}$ Although the high frequency of retelling of this story does result in some minor variations in the details, the account remains generally verifiable through a multitude of primary sources from the time. The story of this one slave mother and her rebellious act of infanticide became national news, as newspaper articles from New York, Kentucky, and Cincinnati (at least) can be located for reporting of it.

In the book Reminiscences of Levi Coffin, which was originally published in 1876, the author admits that he himself was to be involved in the safe conduction of Garner's escape party to a connection in the Underground Railroad where they were to be led north to freedom in $1856 .{ }^{231}$ Coffin claims, "Perhaps no case that came under my notice, while engaged in aiding fugitive slaves, attracted more attention and aroused deeper interest and sympathy than the case of Margaret Garner, the slave mother, who killed her child rather than see it taken back to slavery.",232

From the astounding amount of evidence available on the Margaret Garner case, her story can be verified according to the norms of modern social science; that is, it can be corroborated in multiple, reliable independent sources. She was a twenty-two-year-old

\footnotetext{
${ }^{230}$ For the Margaret Garner story many secondary, and some primary sources can be utilized. See Levi Coffin, Reminiscences of Levi Coffin (Cincinnati: The Robert Clarke Co., 1898) [orig. published 1876], 557-567. See also Julius Yanuck, "The Garner Fugitive Slave Case," The Mississippi Valley Historical Review (June 1953), 47-66; Weisenburger, Modern Medea; Davis, Women, Race, and Class, 21-29; Bauer, "Day to Day Resistance to Slavery," 416; and J. Winston Coleman, Jr., Slavery Times in Kentucky (Chapel Hill: The University of North Carolina Press, 1940), 208-9.

${ }^{231}$ Coffin, Reminiscences, 559.

${ }^{232}$ Ibid., 557.
} 
pregnant plantation slave who, in January 1856, attempted and nearly succeeded in escaping slavery and the alleged sexual exploitation that she had endured. Although she became the central figure in the events that followed, she did not act alone. Rather, an atypically large group of runaway slaves (seventeen in all) were involved and banded together to leave their plantations in border counties of Kentucky in hopes of connecting with the Underground Railroad and finding freedom in the North. Among the group were Margaret Garner, her husband Simon, Jr., their four children (two boys and two small girls), Simon Jr.'s parents Simon and Mary Garner, and nine other slaves from neighboring plantations.

In dramatic fashion the fugitives made their escape over the invisible line between slavery and freedom by crossing the then frozen Ohio River, which had created for them a solid footbridge, later referred to by some as the "Fugitive Slave Bridge." ${ }^{233}$ Finding themselves then in Ohio, a border free state, they quickly made their way to Cincinnati. There the groups separated in an attempt to better blend in, and the Garners sought temporary refuge in the home of Elijah Kite, a free black man who was to aid them in their escape with direction from abolitionist Levi Coffin, already heavily involved at this time in the transport of fugitive slaves on the Underground Railroad. Unfortunately, the Garner family had been spotted and soon the slave-owners Archibald Gaines and James Marshall arrived from Kentucky with their lawyers and deputy U.S. marshals from both Covington and Cincinnati in tow, prepared to capture the fugitives.

${ }^{233}$ Weisenburger, Modern Medea, 153. 
Sensing that hope of freedom was lost, Margaret Garner resolved not to allow her children to be captured alive. She found a large knife and used it on the throat of her three-year-old daughter Mary, ending her life. She also attempted to kill her other children, stabbing both of the boys, and once the knife was taken away, hitting her youngest baby, Priscilla, in the face with a shovel. Her attempts to end the lives of all of her children were not successful, and all but Mary survived. The entire family was arrested, providing a glimpse into the criminalization of victims as well as perpetrators in the dominant society. The difficulty of distinguishing the two under white supremacist thinking, and in the court proceeding that followed, in which she was accused of murder, but not tried before her return to her owner, is of special significance to my argument. ${ }^{234}$

No one could have initially realized the import of the Garner case. It was at the outset to be a simple hearing for a fugitive slave warrant, which usually resulted in a release of the fugitives to their owners within a day or so. Instead though, residents of Cinncinnati, city officials, and judicial powers were immediately divided on how justice should be served. For the first time in history a fugitive slave who was to be expedited back to slavery due to the federal Fugitive Slave Act was also entangled in a possible indictment under state law for murder charges. No precedent existed involving a capital crime and a fugitive slave. ${ }^{235}$ What followed was a bitter month long fight in trial involving state's right's issues, and questioning of the constitutionality of the Fugitive Slave Law itself. Meanwhile the family remained imprisoned, as if they were all first and

\footnotetext{
${ }^{234}$ This account of details regarding the Margaret Garner act is summarized from multiple secondary and primary sources. See Coffin, Reminiscences, 557-567; Yanuck, "The Garner Fugitive Slave Case," 47-66; See also Weisenburger, Modern Medea; See also Davis, Women, Race, and Class, 21-29; Bauers, "Day to Day Resistance to Slavery," 416; and Coleman, Jr., Slavery Times in Kentucky, 208-9.

${ }^{235}$ Weisenburger, Modern Medea, 112.
} 
foremost criminals and a danger to society. Also, a public opinion battle raged on as well as Garner's story was used by both pro and anti-slavery defendants. Many northerners argued that the state of Ohio should not have to accept the federal law's intervention in this case because that would imply that more weight was given to claims on property than on violent crimes against people. On the other hand, southerners wanted a guarantee that the federal law would be upheld and they could count on speedy return of their 'property' when necessary. ${ }^{236}$

Most famously, abolitionists saw an opportunity to make a statement and so, swooped in as they sometimes did, and claimed Margaret in that moment-arguing that Margaret had killed her baby to save it from suffering the injustices of slavery and that the system was really to blame. They did not want her sent back to servitude.

Garner's motivations for killing her children appeared obvious to news reporters who recaptured the dramatic events in detail for their readers in the days that followed. The first published news regarding the event ran on January 29, 1856 in the Cincinnati Gazette, and was subtitled "A Slave Mother Murders her Child rather than see it Returned to Slavery." 237 What's apparent about the Garner case is the role of the media in circulating the story, conventionalizing the idea of slave mother as mother-victim or mother-victimizer; either way a desperate, distorted view of motherhood that otherwise

\footnotetext{
${ }^{236}$ Ibid., 6 \& 112.

${ }^{237}$ The Cincinnati Gazette, "Arrest of Fugitive Slaves: A Slave Mother Murders her Child rather than see it Returned to Slavery," January 29, 1856, as published in Weisenburger, Modern Medea, 87.
} 
became iconic in the culture, as enslaved women's "good" mothering was either invisible or not in the interest of the powerful to narrate and circulate. ${ }^{238}$

This same day a similar article would run in the Cincinnati Enquirer with many of the same details made available in the Gazette. Later, during the inquest that ensued, Margaret's mother-in-law Mary Garner would testify that Margaret had told her, "Mother, I will kill my children before they shall be taken back, every one of them.,"239 Mary Kite, residence of the house and witness to the act of infanticide, corroborates this motive by testifying that Margaret also told her that "she would rather kill them all than have them taken back over the river. ${ }^{240}$

In the end, the Garners were returned to their owner and to slavery rather than granted legal standing and personhood to be accountable for Margaret Garner's actions towards her children. The law re-affirmed, as we have seen that it generally did in antebellum times, that Margaret Garner was most importantly an economic owned by her master. Regardless of what she was told, she had blatantly claimed her own body and that of her children, and she made no apologies for this. She chose for her child, the extension of herself that her body had created, to die rather than to add to the coffers of her master, or to be raised in the system that had exploited her intimate self.

Her sensationalist story has continued to echo throughout the last century and a half as the example of female slave infanticide because, as I have suggested, it makes enslaved motherhood monstrous in ways that upheld existing power relations in general

\footnotetext{
${ }^{238}$ The only "good" mothering role available to enslaved women was that of "mammy," who saved her good mothering behavior primarily for white families. Collins, Black Feminist Thought, 67-78.

${ }^{239}$ New York Times, "The Slave Tragedy in Cincinnati," February 2, 1856.

${ }^{240}$ Ibid.
} 
and the economy of slavery in particular. She continues to play the role of emblem and symbol in this space in history, repeated regularly in U.S. media, cultural, and academic venues. Due to the striking detail that has been accounted in news sources from the time this story has remained in the minds of historians and writers who seek a graphic story of infanticide for myriad purposes. Several historians and black feminists, including Deborah Gray White, Angela Davis, Mark Reinhardt, Julius Yanuck, and Alice and Raymond Bauer, have utilized Garner's story in their analysis of infanticide and gendered resistance under slavery. ${ }^{241}$

In his book Modern Medea, Weisenburger raises questions about how we should interpret Garner's actions. He rhetorically asks if her actions were rebellious, and answers for himself that they certainly were, and should be recognized as such because “as for infanticide, what had Margaret Garner done? Destroyed her mater's property..." ${ }^{242}$ Although Garner's story is the most sensationalized, her continued role as our modern symbol of female slave infanticide should not overshadow those stories of other women who participated in this same method of resistance. Records of their resistance are less extensive, and therefore, details surrounding their acts are less understood. After all, we can only recreate history from the evidence that we have.

The second piece of evidence of infanticide comes from a WPA narrative of exslave Lou Smith. In her narrative Smith tells us of a woman who was owned by a cruel

\footnotetext{
${ }^{241}$ White, Ar'n't I a Woman; See also Davis, Women, Race, and Class; Mark Reinhardt, "Who Speaks for Margaret Garner? Slavery, Silence, and the Politics of Ventriloquism," Critical Inquiry Vol. 29 (2002), 81119; Yanuck, "The Garner Fugitive Slave Case"; Bauer, "Day to Day Resistance to Slavery;" Garner's story has also been memorialized in books like Toni Morrison's Beloved published in 1987 (and later turned into a movie) and Steven Weisenburger's 1998 publication titled Modern Medea: a Family Story of Slavery and Child-Murder from the Old South. It has also been reproduced in multiple plays and research papers. Cameron McWhirter, Cincinnati Enquirer, "A Remnant of Slavery's Horror," October 2, 1998. ${ }^{242}$ Weisenburger, Modern Medea, 77.
} 
neighboring plantation master, and who ultimately found that the only way that she could resist the impending placement of her baby in the slave market was to take its life. Smith says that this

woman was the mother of several chillun and when her babies would get about a year or two of age he'd [her master] sell them and it would break her heart. She never got to keep them. When her fourth baby was born and was about two months old she just studied all the time about how she would have to give it up and one day she said, "I just decided I'm not going to let old Master sell this baby; he just ain't going to do it." She got up and give it something out of a bottle and purty soon it was dead. 'Course didn't nobody tell on her or he'd of beat her nearly to death. ${ }^{243}$

The mother in this case seems to have known that she acted defiantly by making her own decision about the fate of her baby's body. Smith evidently knew it was rebellious and resistant since she adds that it was understood by the other slaves that telling on her would result in severe punishment for her act. Of significant import here is the collaboration by the slave community — 'didn't nobody tell on her'—and the extreme lack of choices facing the mother: her own life and death was at stake. This story is an example of making a choice when the scenario offered no choice.

In 1846 ex-slave Lewis Garrard Clarke published his own narrative in the lengthy form of a book called Narratives of the Sufferings of Lewis and Milton Clarke. When relating his answer to the question, "Have you ever known a slave mother to kill her own children?" (which Clarke said he was often asked in public), he gives us two accounts of infanticide that he was aware of. The fact that this question was posed at all points to narrative expectations in the culture that historians have not inquired into. By

\footnotetext{
${ }^{243}$ WPA Slave Narrative Project, "Lou Smith,” Oklahoma Narratives, Vol. 13 (Interviewed August 12, 1937), 302. See also Dorothy Sterling, ed., We Are Your Sisters: Black Women in the Nineteenth Century (New York: W. W. Norton \& Co., 1984), 57-8.
} 
the 1840s, perhaps official silence or folklore surrounded this 'open secret.' If the question can be posed, it seems to me, it has to be answerable and Clarke proves to be far from perplexed by the asking of it. In fact, he seems to effortlessly answer with two precise stories. The first is described as follows: "There was a slave mother near where I lived, who took her child into the cellar and killed it. She did it to prevent being separated from her child." He follows this infanticide account with a second: "Another slave mother took her three children and threw them into a well, and then jumped in with them, and they were all drowned." ${ }^{244}$ Not only does Clarke provide us with two accounts of infanticide committed by slave mothers, but he points out that the first mother had done so to keep from being separated from her child. One of the distinctive features of both stories has to do with the gesture of submersion or descent. The mothers do not just kill their children, but they also separate them from society, putting their bodies deeper into the earth (the cellar) or into the water-and indeed, sometimes following themselves. These gestures could be read as an alternative geography of freedom; freedom through death. The second story in particular might be open to such a reading, since the mother joined her children in the drowning, a situation documented by other historians of slavery. ${ }^{245}$ It is likely that, similar to the preceding story provided by Lou Smith, this mother was afraid of the separation of her child and the deliverance of it into the slave market, where any number of fates could befall it. Infanticide was her answer to the question of, how to choose her

\footnotetext{
${ }^{244}$ Lewis Garrard Clarke, Narratives of the Sufferings of Lewis and Milton Clarke, Sons of a Soldier of the Revolution, During a Captivity of More Than Twenty Years Among the Slaveholders of Kentucky, One of the So Called Christian States of North America, Documenting the American South (University Library: The University of North Carolina Chapel Hill, 1999 [Originally published in 1846], 76; For the first account See also Johnson, Soul By Soul, 34.

${ }^{245}$ Jane Landers, "'In Consideration of Her Enormous Crime": Rape and Infanticide in Spanish St. Augustine," in The Devil's Lane: Sex and Race in the Early South (New York: Oxford University Press, 1997), 205-214. Landers relates a similar narrative regarding an eighteenth-century Spanish slave woman who jumped into a well with her children and drowned them.
} 
child's fate herself, and how to defend her offspring. Clarke also comments on the acts of infanticide himself. He says,

Other instances I have frequently heard of ... At the death of many and many a slave child I have seen the two feelings struggling in the bosom of a mother--joy that it was beyond the reach of the slave monsters, and the natural grief of a mother over her child. In the presence of the master, grief seems to predominate; when away from them, they rejoice that there is one whom the slave-driver will never torment. ${ }^{246}$

What Clarke is pointing to is key. As I have previously mentioned, these mothers did not kill their children due to lack of maternal love, but instead they did it so that their child could be "one whom the slave-driver will never torment." They chose to live with grief rather than allow their children to live with misery, thus performing the ultimate role of self-sacrificing motherhood. The second point Clarke makes is profound: that mothers lived with "two feelings," that their gestures inhabited a space of suspended, unresolved meaning, a memory marker of violence.

The next piece of evidence comes from Frederick Law Olmsted's published journal a Journey in the Seaboard Slave States, from 1856. As Olmsted traveled through Alabama he stated that, "A negress was hung this year in Alabama, for the murder of her child. At her trial, she confessed her guilt. She said her owner was the father of the child, and that her mistress knew it, and treated it so cruelly in consequence, that she had killed it to save it from further suffering." ${ }^{247}$ Like the mother discussed by Clarke, this mother chose her own grief over her child's, as slave women were often choosing from among a range of sufferings; a spectrum of griefs. Indeed, the radical and unsettling dimension

\footnotetext{
${ }^{246}$ Clarke, Narratives of the Sufferings of Lewis and Milton Clarke, 76. See also Johnson, Soul By Soul, 34.

${ }^{247}$ Olmsted, Frederick Law, a Journey in the Seaboard Slave States: With Remarks on Their Economy, Documenting the American South (University Library: The University of North Carolina Chapel Hill, 2001 [Originally published in 1856], 601-2; See also White, Ar'n't I a Woman?, 88.
} 
here is the haunting and unfinished quality of these gestures. Hardly final or finite, they live on in memory, in the culture, in the body of the mother herself; their life is in the narration and memory of an unresolved struggle, one still with us in the present.

The final, piece of evidence that I was able to corroborate through location of primary source materials is the story of a slave named Sylva, who is said to have taken the lives of, not one, but all thirteen of her children. I was struck by the substantial number of children listed, but this was a normal number of pregnancies for a healthy rural woman in antebellum America, and many female slaves were expected to reproduce many children (as previously noted), so she could have just been resolute to terminate each of her children's lives as she claimed. In Parsons's 1855 publication of An Inside View of Slavery, he relates a story told to him by the mistress of the plantation on which Sylva lives. He was told that "Sylva says... that she has been the mother of thirteen children, every one of whom she destroyed with her own hands, in their infancy, rather than have them suffer in slavery!"248 While Parsons does not elaborate on this story, or his own thoughts of it, we do learn of the acts of infanticide while hearing about the abuses that Sylva has suffered at the hands of her master. This left me to ponder whether Parsons does not discuss the infanticide because he understands the mother's motivation, to save her children from such cruel treatment, or if the author leaves this story with an exclamation point due to the anti-slavery context/audience of his time. ${ }^{249}$ Coming near the time of the Garner case, it seems that if I trust the story as an historian, there is a settled and conventionalized way to make meaning of infanticide for Sylvia (protecting

\footnotetext{
${ }^{248}$ Parson, An Inside View of Slavery, 212. See also Bauer, "Day to Day Resistance to Slavery,"417.

${ }^{249}$ Parson, An Inside View of Slavery, 212. Though I was able to locate six other cited acts of infanticide, they are completely based on secondary source evidence, and therefore the causes of the acts are widely unknown.
} 
her children from slavery) and one ready to hit the media the very next year and circulate as acceptable folklore, shocking but not controversial per se, appealing to a shared sense of embattled motherhood under slavery.

While it was possible to find many discussions of certain cases of infanticide among the pieces of enslaved women's lives left in record, it was more difficult to locate any real discussion on abortion, even though it is maintained that it existed in slave communities. I was, however, able to locate several instances still.

The first of these pieces of evidence comes from a plantation journal, which would have likely been updated by overseers and masters to keep records on slaves' condition, work, whereabouts, and issues. Although the Ferry Hill Plantation Journal was written between January 4, 1838 and January 15, 1839 by John Blackford, it was not published until 1961 with editing by Fletcher M. Green. In the journal we read that, "Daph miscarryed two children this morning. sent for Mrs. Fry who came, she is quite ill. the two children which Daph miscarryed she is supposed to have gone with 4 months Both female. It was an hour or upwards between their birth. It is thought she took medicine to produce their destruction." ${ }^{250}$ Blackford doesn't relate his views about this incident. He was likely angered at the 'destruction' of the children that would have added to his wealth, as he (as a slaveholder) would have felt entitled to them.

The second piece of evidence comes in the form of a medical journal article from the antebellum South. In 1860 Dr. John H. Morgan not only published his article "An Essay on the Causes of the Production of Abortion among our Negro Population" in

\footnotetext{
${ }^{250}$ Fletcher M. Green, Ferry Hill Plantation Journal: January 4, 1838- January 15, 1839, Documenting the American South (University Library: The University of North Carolina Chapel Hill, 1998 [Originally published in 1961]), 25-6. See also White, Ar'n't I a Woman, 84.
} 
the Nashville Journal of Medicine and Surgery, but he also read it to the Rutherford County Medical Society that same year. ${ }^{251}$ Within this piece of evidence we can not only locate a professional medical opinion that abortion was indeed being utilized by slave women, but Morgan also notes two actual acts of abortion that seem authentic (as in, verifiable by modern social science standards). We will start by analyzing his expert opinion on the matter, and then move on to the abortive acts.

Dr. Morgan is writing on abortion among slaves because there is a market for his form of knowledge. ${ }^{252} \mathrm{He}$ first admits that he believes the most common causes of sterility and abortion to be hard labor and mistreatment put on slave women while pregnant. He adds that sometimes slave women are "willing and even anxious to avail themselves of an opportunity to effect an abortion or to derange menstruation-" the latter referring to a contraception of some sort. ${ }^{253} \mathrm{He}$ continues by adding that "the remedies mostly used by the negroes to procure abortion are the infusion or decoction of tansy, rue, roots and seed of the cotton plant, pennyroyal, cedar berries and camphor, either in gum or spirits," and some of these items are readily available to them in local gardens. ${ }^{254}$ Morgan also declared that he has been questioned by blacks if camphor would make a woman miscarry, and he attributes the length of the list of abortives being attempted to the ambiguity revolving around which medicines are the most effective. ${ }^{255}$

\footnotetext{
${ }^{251}$ John H. Morgan, M.D., "An Essay on the Causes of the Production of Abortion among our Negro Population," Nashville Journal of Medicine and Surgery (August 1860).

${ }^{252}$ Laura Briggs, "The Race of Hysteria: 'Overcivilization' and the 'Savage' Woman in Late NineteenthCentury Obstetrics and Gynecology," American Quarterly, Vol. 52, No. 2 (2000) 246-273. By the middle of the nineteenth century a discourse on African women's bodies was well established, and newly accepted and of great interest was the discourse among physicians of obstetrics and gynecology.

${ }^{253}$ Morgan, "An Essay on the Causes," 117.

${ }^{254}$ Ibid., 117-8.

${ }^{255}$ Ibid.,119.
} 
Although Morgan writes that his medical opinion is that "it is a very rare thing for negroes to resort to mechanical means to effect an abortion," he relates, in his essay, contradictory and graphic acts, including a specific case where a black slave woman was examined and was found to have deliberately procured an abortion by using mechanical means, and she was successful. ${ }^{256}$

The other case that Morgan includes in his essay is of most interest to me because confession was claimed to have been attained from the slaves that used abortives. Dr. Morgan was informed by a Dr. Smith that there was a family of slave women who were suspected of inducing abortions for a multi-generational time span. Even when the master had sold the suspect slaves and replaced them with women "who were in the habit of having children every eighteen months or two years," he noticed that "every conception was aborted by the fourth month. The negroes finally confessed that they did take medicine for this purpose, and showed their master the weed which was their favorite remedy. ${ }^{, 257}$ One must wonder how many times these slaves had successfully claimed their bodies and cheated their owner out of further 'property.'

Analyzing this evidence, both in volume and in credibility, I would conclude that abortion and infanticide undoubtedly did occur in the antebellum slave south and can be valued by historians as female resistance to slavery. Their value as resistance exists in the agency that was required from black slave women to commit these acts, and the rebellious nature at the heart of them, as preserved in oral tradition and folklore. Also, it is not necessary to deem infanticide and abortion common in order to validate these

\footnotetext{
${ }^{256}$ Ibid., 120.

${ }^{257}$ Ibid.," 122 . While Dr. Morgan does support the theory that slave women were known to be using abortion as a reproductive choice, he does not conclude with any opinions on the motivations or on this as a method of resistance as his essay is intended for a medical audience only.
} 
methods of resistance among slave women. Previous scholars have possibly used the ambiguous evidence to prove a point when it was necessary for women's history that it be done. They understandably desired to create a space where slave women would be valued as contributors to resistance of the system of slavery.

Female slaves' reproductive decisions, namely abortion and infanticide, are just one space where female slaves contributed to resistance against the system that intimately oppressed them through rape and forced breeding. Female slave history has suffered from the lack of sources that are available to tell their story; to share their voices; but in searching the silences and gaps I hope that their stories are not lost. Our modern understanding of resistance includes things like everyday resistance and, therefore, it should become more inclusive to female resistance to slavery through reproductive choices as well. If we are to accept masculinist methods of resistance as resistance, then we must be prepared to welcome other gendered forms of resistance utilized by female slaves. Women undoubtedly found their own methods of resistance where it seemed there may have been none. They were not silent, some historians have made it seem, and as this becomes more apparent, there are many of us who demand to find their voices. Indeed, as this thesis has tried to argue, the meaning is in the telling and retelling of these stories by multiple parties in multiple venues, but especially by African American oral tradition. 


\section{Conclusion}

"The bill of sale!" Those words struck me like a blow. So I was sold at last! A human being sold in the free city of New York! ... I am deeply grateful to the generous friend who procured it [the bill], but I despise the miscreant who demanded payment for what never rightfully belonged to him or his.

- Harriet A. Jacobs $(1857)^{258}$

Own, v.t. [from the adjective]-

1. To have the legal or rightful title to; to have the exclusive right of possession and use.

- Webster's American Dictionary of the English Language (1828) ${ }^{259}$

In the beginning of this thesis I asked the question, "Who owns this body?" in regards to the antebellum slave woman. It is an undeniably problematic concept, ownership of enslaved females' bodies in the Old South. The nineteenth century theory of ownership certainly focuses on the "legal and rightful title" of the owner, but what about the "right of possession and use" ${ }^{260}$ Enslaved women claimed the possession and use of their intimate selves time and again in innumerable ways. Regulation has undoubtedly argued that ownership lay exclusively with those whites who controlled and supported the system of slavery that existed in this time and place. However, the actions that enslaved women employed, time and time again, to resist their intimate oppressions through reproductive choice shows us that they did not easily agree. In a society that constantly attempted to control them, relegating them to chattel with no legal say in what happened to their bodies, they still resisted and chose to take control of their physical selves. This supports the idea that, in direct opposition to the body politics that controlled

\footnotetext{
${ }^{258}$ Jacobs, Incidents in the Life of a Slave Girl, 200.

${ }^{259}$ Webster's American Dictionary of the English Language Online, 1828 Edition, v.t. "own." ${ }^{260}$ Ibid.
} 
their lives, enslaved women believed that their bodies were still inherently their own. Indeed, they sometimes fought for and claimed themselves.

Towards the end of her narrative, Jacobs shares her experience at being purchased by a dear friend, who sought to end her conflicting and dangerous ownership by the controlling and vindictive slaveholding family of Dr. Norcom. While, her friend clearly sought this act to be a way of freeing Jacobs from her oppressor, she didn't perceive it that way. She had never considered herself his property and was incensed at his receipt of payment for her, since she had "never rightfully belonged to him and his." ${ }^{261}$ Amy Post, a member of the Society of Friends in New York, and a close friend of Harriet's says that when she wrote to her to share the news of her purchase "She was grateful ... but the idea of having been bought was always galling to a spirit that could never acknowledge itself to be chattel." ${ }^{262}$ She told Post that "the freedom I had before the money was paid was dearer to me. God gave me that freedom; but man put God's image in the scales with the paltry sum of three hundred dollars." ${ }^{263}$ While she was undoubtedly relieved to be free of her pursuer (at this point having escaped to New York and been chased off and on by her title owner), she does not hide from her readers her disappointment that the chase ended on terms governed by the legal arrangements that had been laid out to ensure the system of her oppression. The freedom she had before her purchase by a friend, the freedom she had laid claim to, in opposition to the man and the law and the system that attempted to control her body, that was the freedom that she valued. She wanted her freedom to be delivered with the prohibition of slavery, or the denunciation of the legal claims that she

\footnotetext{
${ }^{261}$ Jacobs, Incidents in the Life of a Slave Girl, 200-204.

${ }^{262}$ Ibid., 204.

${ }^{263}$ Ibid.
} 
felt were invalid. Instead, her purchase in the end did not tell of her resistance, but instead a frustrating acquiesce to the slave system. She laments quite openly, "I was robbed of my victory," and claims that she did not want to be free until all bondspeople were freed from slavery. ${ }^{264}$

While Jacobs has served as my emblem throughout this thesis, her narrative does not stand alone. She allows us a window into her life with her writing, offering herself as an example of a bondswoman tormented with the fear of sexual coercion, forced to make choices about her intimate self that were not easy, and robbed of a normal motherhood, yet she also shares something else. She shows us what it looked like for an enslaved woman who knew that she should not be claimed solely and unquestioningly by her socalled master, and who subsequently fought for her right to claim her body and her intimate self. She believed so strongly in her right to this claim that she locked herself away in a small wooden space for seven years. She literally took control of her own body with this act, and effectively took control of the bodies of her children as well, because she did not believe that they were property to be owned.

Enslaved women in the Old South lived daily in a struggling space of intersecting oppressions. Their particular predicament created a reality where they could leave behind little of their own voice, had no legal protection from the rape of their bodies, and had little say over when or with who they reproduced. This oppression of their intimate selves sometimes resulted in their own feminist methods of resistance through reproductive choice (infanticide and abortion), which negatively affected the system that they were ordered to perpetuate.

${ }^{264}$ Ibid. 
Nineteenth century antebellum America was a place fraught with ambiguities and uncertainties with regard to the claims made on the bondspeople in its population. While many were beginning to ask tougher questions and point fingers toward the ongoing hypocrisy prevalent in the legal and judicial system, much of the white population of the south was prepared to (and would) go to war over the question of who owned the bodies of slaves. While the immediate legal claims to the intimate spaces of enslaved women would fall apart after the Civil War and Emancipation, we can see that the controlling images that were invented to represent black women in the times of slavery only progress to encapsulate more and more modern issues, and have never really disappeared, carrying with it a continued if less visible claim on the bodies of these women. The black woman's body in antebellum America was seen as "either a sexualized mythology or a neutered anomaly, defined by her sexuality or lack of it... understood to represent that which could be dominated and that which could be possessed, especially sexually," images that were "national, racial, and historical hallucinations," as Maya Angelou put it, but as time has gone on, we see that 'national hallucinations' die hard. ${ }^{265}$

In the twenty-first century we are left with a continued dialogue about the black woman's body, which remains of interest to many people other than herself, and stereotypes still abound. Where the controlling images of the mammy, the jezebel, the matriarch, and the breeder left off, other images have evolved. ${ }^{266}$ An important contribution of this thesis is to make explicit the ways in which enslaved women (and

\footnotetext{
${ }^{265}$ Willis, The Black Female Body, 2-3. Maya Angelou, "They Came to Stay," in Brian Lanker, I Dream a World: Portraits of Black Women Who Changed America (New York: Stewart, Tabori, and Chang, 1989), 9.

${ }^{266}$ Collins, Black Feminist Thought; See also Painter, "Hill, Thomas, and the Use of Racial Stereotype," 200-214.
} 
men) only had legal identities beyond chattels as criminals in the legal system, a sobering pattern in light of on-going inequitable treatment of African Americans in the prison system, a system some describe today as the "new Jim Crow."267

While sources from the nineteenth century are largely masculinist in nature, it is possible, with the use of oral history sources like the WPA Slave Narratives and postabolition autobiographies, newspapers, plantation log books, second-hand accounts, and court records to reconstruct the unique history of enslaved women themselves with some of their own words, and it continues to be important to seek these sources out and do so. I hope that this thesis has illuminated a path that other historians can follow in this regard, and that the dialogue is never over between the past and the present.

In a history that easily misconstrues ownership as a legally defined reality, it is not easy, but is still crucial, to look beyond conspicuous sources, between the things that are said, and at the voices that are sometimes not there at all. Bills of sale, auction records, slave codes, plantation journals, and court reports logged the purchase of human beings, pointing clearly to the ownership of these bodies by others, but I argue that they claimed their bodies in ways previously ignored. A more conclusive definition of ownership, one that takes into account the narratives left behind for us and the important and personal stories that they relate, will grant an equal claim to ownership of the enslaved women themselves. As they sought ways to claim their bodies through methods of resistance focused on their most intimate selves, they did not allow the definitions of their times to stop them from making their own (sometimes impossible) choices.

${ }^{267}$ Michelle Alexander, The New Jim Crow: Mass Incarceration in the Age of Color Blindness (New York: New Press, 2010). 
While regulation provided their oppressors with the means to rape their bodies lawfully, sometimes producing children from these unions, and practices of breeding meant to ensure their race's perpetual subjugation as a commodified source of labor (and slave women as biopower) it was the enslaved women themselves who controlled the outcomes of these situations when they controlled their reproduction through abortion and infanticide. Some women, like Harriet Jacobs, found ways to carve out choice where they had been given no choices, and power in a space where they were called powerless. Their stories deserve equal purchase in the historical record with the more 'accepted' social science sources. The methodology employed by historians needs to stretch and grow to encompass the stories, no matter how difficult to find, of the enslaved women who claimed themselves. 


\section{Bibliography}

Primary Sources:

Botkin, B. A. Lay My Burden Down: A Folk History of Slavery. Chicago: University of Chicago Press, 1945.

Brown, William W. Narrative of William W. Brown, A Fugitive Slave. Written by Himself. Boston: Published at the Anti-Slavery Office, 1847. http://www.gutenberg.org/files/15132/15132-h/15132-h.htm.

The Cincinnati Enquirer, “A Stampede of Slaves: A Tale of Horror,” January 29, 1856. www.enquirer.com/editions/1998/10/02/loc_w_slave02.html.

Cincinnati Gazette, "Arrest of Fugitive Slaves: A Slave Mother Murders her Child rather than see it Returned to Slavery," January 29, 1856. Published in Steven Weisenburger's Modern Medea: A Family Story of Slavery and Child-Murder from the Old South. New York: Hill and Wang, 1998.

Clarke, Lewis Garrard. Narrative of the Sufferings of Lewis Clarke: During a Captivity of More Than Twenty-Five Years, Among the Algerines of Kentucky, One of the So Called Christian States in America. Dictated by Himself. Documenting the American South. Chapel Hill: University of North Carolina, 1999 [originally published in 1846]. http://docsouth.unc.edu/clarke/clarke.html.

Cobb, Thomas R. R. An Inquiry into the Law of Negro Slavery in the United States of America. New York: Negro Universities Press, 1968 [originally published in 1858].

Coffin, Levi. Reminiscences of Levi Coffin, The Reputed President of the Underground Railroad; Being a Brief History of the Labors of a Lifetime in Behalf of the Slave, With the Stories of Numerous Fugitives, Who Gained Their Freedom Through His Instrumentality, and With Many Other Incidents. Cincinnati: The Robert Clarke Co., 1898 [originally published in 1876].

Creswell's Executor v. Walker, 37 Alabama, 229 (1861).

Cushing, John D., ed. The First Laws of the State of Virginia. Wilmington: Michael Glazier, Inc., 1982 [originally published in 1783].

Dred Scott v. Sandford, 60 U.S., 393 (1857).

Gates, Jr., Henry Louis, ed. Six Women's Slave Narratives. New York: Oxford University Press, 1988. 
George v. State, 37 Mississippi, 316 (1859).

Gilbert, Olive, ed. The Narrative of Sojourner Truth, Dictated by Sojourner Truth Boston: The Author, 1850. digital.library.upenn.edu/women/truth/1850/1850.html.

Goodell, William. The American slave code in theory and practice: its distinctive features shown by its statutes, judicial decisions, and illustrative facts. Ann Arbor: University of Michigan Library, 2005 [originally published in 1853].

Green, Fletcher M., ed. Ferry Hill Plantation Journal: January 4, 1838- January 15, 1839. Documenting the American South. University Library: The University of North Carolina Press at Chapel Hill, 1998 [Originally published in 1961]. http://docsouth.unc.edu/blackford/blackford.html.

Gwaltney, John Langston. Drylongso: A Self-Portrait of Black America. New York: Random House, 1980.

Hening, William Waller, ed. The Statutes at Large; Being a Collection of All the Laws of Virginia, From the First Session of the Legislature, in the Year 1619 (Vol. 8). Charlottesville: University of Virginia Press, 1969 [originally published in 1821].

Jacobs, Harriet A. Jean Fagan Yellin, ed., Incidents in the Life of a Slave Girl: Written by Herself.. Cambridge: Harvard University Press, 1987 [originally published in 1861].

Keckley, Elizabeth. Behind the Scenes, Or Thirty Years a Slave, and Four Years in the White House. New York: G.W. Carleton \& Co., 1868. http://www.gutenberg.org/files/24968/24968-h/24968-h.htm.

The Liberator, "Dreadful Slave Tragedy," early February 1856 (exact date unknown), Page 1.

Mattison, H. Louisa Picquet, the Octoroon: A Tale of Southern Slave Life or Inside Views of Southern Domestic Life. New York: Published by the Author, 1861.

Morgan, John H., M. D., "An Essay on the Causes of Production of Abortion Among Our Negro Population," Nashville Journal of Medicine and Surgery, Vol. 19 (August 1860), 117-123.

New York Daily Times, “The Cincinnati Slave Case,” March 11, 1856, Page 4. www.nytimes.com.

New York Daily Times, “The Fugitive Slave Case in Cincinnati,” February 4, 1856, Page 
8. www.nytimes.com.

New York Daily Times, “The Kentucky Slaves,” February 12, 1856, Page 1.

www.nytimes.com.

New York Daily Times, “The Slave Tragedy in Cincinnati," February 2, 1856, Page 3. www.nytimes.com.

Olmsted, Frederick Law. A Journey in the Seaboard Slave States: With Remarks on Their Economy. Documenting the American South. University Library: The University of North Carolina Chapel Hill, 2001 [originally published in 1856].

http://docsouth.unc.edu/olmsted/olmsted.html.

Parsons, Charles G., M. D. Inside View of Slavery: or a Tour Among the Planters. Boston: John P. Jewett and Company, 1855.

Rawick George P., ed. The American Slave: A Composite Autobiography. Westport, CT: Greenwood Publishing Co., 1972. [Publication of Slave Narrative Collection interviews submitted to the Library of Congress in 1941. 19 Volume Set].

Schneider, Dorothy and Carl J. Schneider, eds. An Eyewitness History of Slavery in America: From Colonial Times to the Civil War. New York: Checkmark Books, 2001.

Slave Killing Prevention Act of 1774, ch. XXXI §I N.C. Laws. Acts of North Carolina General Assembly, 1774 (March 2, 1774- March 25, 1774), Vol. 23. http://docsouth.unc.edu/csr/index.html/document/csr23-0054

State of North Carolina v. Boone, 1 N.C. 191 (N.C. Conf 1801). http://moglen.law.columbia.edu/twiki/pub/AmLegalHist/TedProject/Boon.pdf

State of Missouri v. Celia, a Slave (1855).

State of North Carolina v. Mann, 13 North Carolina, 263 (1829).

Stephen v. State of Georgia, 11 Georgia, 225 (1852).

Sterling, Dorothy, ed. We Are Your Sisters: Black Women in the Nineteenth Century. New York: W. W. Norton \& Company, Inc., 1984.

Stroud, George M. A Sketch of the Laws Relating to Slavery in the Several States of the United States of America. New York: Negro Universities Press, 1968 [originally published in 1856]. 
Truth, Sojourner. "Ain't I a Woman?" Women's Convention, Akron, Ohio, 1851. Online at: http://www.fordham.edu/halsall/mod/sojtruth-woman.asp

U. S. Congress. House. An Act to amend, and supplementary to, the Act entitled "An Act respecting Fugitives from Justices, and Persons escaping from the Service of their Masters," approved February twelfth, one thousand seven hundred and ninety-three, $31^{\text {st }}$ Cong., ${ }^{\text {st }}$ Sess., September 18, 1850, 462465. U.S. Statutes at Large: 9 Stat. 462 (1850): 60.

U. S. Congress. House. Ohio. Fugitive Slave Law. Resolution of the Legislature of Ohio, relative to the Fugitive Slave Law. May 21, 1856, $34^{\text {th }}$ Cong., $1^{\text {st }}$ Sess., May 21 , 1856, 112. U.S. Congressional Serial Set, 1817-1980. www.infoweb.newsbank.com.

Webster's American Dictionary of the English Language Online, 1828 Edition. http://1828.mshaffer.com.

Works Progress Administration, Slave Narrative Collection. http://memory.loc.gov/ammem/snhtml/snhome.html.

WPA Slave Narrative Project. "Hannah Jones," Missouri Narratives, Vol. 10 (19361938), 214-217. http://memory.loc.gov/ammem/snhtml/snhome.html.

---. "Lou Smith,” Oklahoma Narratives, Vol. 13 (Interviewed August, 12 1937), 300-305. http://memory.loc.gov/ammem/snhtml/snhome.html.

---. "Hilliard Yellerday," North Carolina Narratives, Vol. XI, Part II (1936-1938), 434. Online at http://northcarolinaslavenarratives.wordpress.com/yellerday-hilliard/

---. "Rose Williams," Texas Narratives, Vol. XVI, Part IV (1936-1938), 174. http://memory.loc.gov/cgibin/query/S?ammem/mesnbib:@field\%28AUTHOR+@od1\%28Williams,+Rose $\% 29 \% 29$

Yellin, Jean Fagan, ed. Incidents in the Life of a Slave Girl: Written by Herself. Harriet A. Jacobs. Cambrige: Harvard University Press, 1987 [originally published in 1861].

Yetman, Norman R. Life Under the "Peculiar Institution": Selections from the Slave Narrative Collection. New York: Holt, Rinehart and Winston, 1970.

Secondary Sources (Books and Dissertations):

Abortion in Nineteenth Century America. New York: Arno Press, 1974. 
Accomando, Christina. “The Regulations of Robbers": Legal Fictions of Slavery and Resistance. Columbus: The Ohio State University Press, 2001.

Alexander, Adele Logan. Ambiguous Lives: Free Women of Color in Rural Georgia, 1789-1879. Fayetteville: University of Arkansas Press, 1991.

Alexander, Michelle. The New Jim Crow: Mass Incarceration in the Age of Color Blindness. New York: New Press, 2010.

Aptheker, Herbert. American Negro Slave Revolts. Millwood, N.Y.: Kraus Reprint Co., 1977.

Baptiste, Edward E. and Stephanie M. H. Camp, eds. New Studies in the History of American Slavery. Atlanta: University of Georgia Press, 2006.

Bartley, Numan V. The Evolution of Southern Culture. Athens: University of Georgia Press, 1988.

Blassingame, John W. The Slave Community: Plantation Life in the Antebellum South. New York: Oxford University Press, Inc., 1972.

Block, Sharon. Rape and Sexual Power in Early America. Chapel Hill: University of North Carolina, 2006.

Bordewich, Fergus M. Bound for Canaan: The Epic Story of the Underground Railroad, America's First Civil Rights Movement. New York: Amistad, 2005.

Buchanan, Thomas C. "The Slave Mississippi: African-American Steamboat Workers, Networks of Resistance, and the Commercial World of the Western Rivers, 1811-1880.” Ph.D. Diss., Carnegie Mellon University, 1998.

Camp, Stephanie M. H. Closer to Freedom: Enslaved Women and Everyday Resistance in the Plantation South. Chapel Hill: University of North Carolina Press, 2004.

Carby, Hazel V. Reconstructing Womanhood: The Emergence of the Afro-American Woman Novelist. New York: Oxford University Press, Inc., 1987.

Clinton, Catherine and Michele Gillespie, eds. The Devil's Lane: Sex and Race in the Early South. New York: Oxford University Press, Inc., 1997.

Cohen, Cathy. Boundaries of Blackness: AIDS and the Breakdown of Black Politics. Chicago: University of Chicago Press, 1999.

Coleman, J. Winston, Jr. Slavery Times in Kentucky. Chapel Hill: The University of 
North Carolina Press, 1940.

Collins, Patricia Hill. Black Feminist Thought: Knowledge, Consciousness, and the Politics of Empowerment. New York: Routledge Press, 2008.

Davis, Angela. Women, Race, and Class. New York: Random House, Inc., 1981.

Davis, Charles T. and Henry Louis Gates, Jr. The Slave's Narrative. New York: Oxford University Press, 1985.

Dittmer, John. Local People: The Struggle for Civil Rights in Mississippi. Urbana : University of Illinois Press, 1994.

DuCille, Ann. Skin Trade. Cambridge: Harvard University Press, 1996.

Dunaway, Wilma A. The African-American Family in Slavery and Emancipation. New York: Cambridge University Press, 2003.

Elkins, Stanley M. Slavery: A Problem in American Institutional and Intellectual Life. Chicago: University of Chicago Press, 1976.

Etter-Lewis, Gwendolyn and Michèle Foster. Unrelated Kin: Race and Gender in Women's Personal Narratives. New York: Routledge, 1996.

Faulkner, Carol. Lucretia Mott's Heresy: Abolition and Women's Rights in NineteenthCentury America. Philadelphia: University of Pennsylvania Press, 2011.

Finkelman, Paul, ed. Rebellions, Resistance, and Runaways Within the Slave South (vol. 13). New York: Garland Publishing, Inc., 1989

---. Slavery and the Law. Madison: Madison House, 1997.

---. Women and the Family in a Slave Society (vol. 9). New York: Garland Publishing, Inc., 1989.

Freedman, Estelle B. Redefining Rape: Sexual Violence in the Era of Suffrage and Segregation. Cambridge: Harvard University Press, 2013.

Frisch, Michael. A Shared Authority: Essays on the Craft and Meaning of Oral and Public History. Albany: State University of New York Press, 1990.

Fox-Genovese, Elizabeth. Within the Plantation Household: Black and White Women of the Old South. Chapel Hill, The University of North Carolina Press, 1988.

Gaines, Kevin K. Uplifting the Race: Black Leadership, Politics, and Culture in the 
Twentieth Century. Chapel Hill: University of North Carolina Press, 1996.

Cotterell, John N. A Collection of Latin Maxims and Phrases Literally Translated. London: Stevens and Hays Law Publishers, 1913. http://archive.org/stream/cu31924021688670\#page/n61/mode/2up.

Gaspar, David Barry and Darlene Clark Hine, eds. More Than Chattel: Black Women and Slavery in the Americas. Bloomington: Indiana University Press, 1996.

Genovese, Eugene D. Roll, Jordan, Roll: the World the Slaves Made. New York: Pantheon Books, 1974.

Gilroy, Paul. The Black Atlantic: Modernity and Double Consciousness. Cambridge, Mass.: Harvard University Press, 1993.

Gluck, Sherna Berger and Daphne Patai. Women's Words: The Feminist Practice of Oral History. New York: Routledge, Chapman, and Hall, 1991.

Gordon-Reed, Annette. Thomas Jefferson and Sally Hemings: An American Controversy. Charlottesville: University of Virginia Press, 1997.

Gregory, Steven. The Black Corona: Race and the Politics of Place in an Urban Community. Princeton: Princeton University Press, 1998.

Higginbotham, Jr., A. Leon. In the Matter of Color: Race and the American Legal Process, the Colonial Period. New York: Oxford University Press, 1978.

Hine, Darlene Clark. Hine Sight: Black Women and the Re-Construction of American History. Brooklyn: Carlson Publishing, 1994.

Hine, Darlene Clark, Wilma King, and Linda Reed, eds. We Specialize in the Wholly Impossible: A Reader in Black Women's History. Brooklyn: Carlson Publishing, Inc.,1995.

Hodes, Martha Elizabeth. White Women, Black Men: Illicit Sex in the Nineteenth-Century South. New Haven: Yale University Press, 1997.

Hoff, Joan. Law, Gender, and Injustice: A Legal History of U.S. Women. New York: New York University Press, 1991.

Hunter, Tera W. To 'Joy My Freedom: Southern Black Women's Lives and Labors After the Civil War. Cambridge: Harvard University Press, 1997.

Hull, Gloria T., Patricia Bell Scott, and Barbara Smith, eds. All the Women Are White, All the Blacks Are Men, But Some of Us Are Brave: Black Women's Studies. New 
York: The Feminist Press, 1982.

Johnson, Michael P. and James L. Roark. Black Masters: A Free Family of Color in the Old South. New York: W.W. Norton, 1984.

Johnson, Walter. Soul by Soul: Life Inside the Antebellum Slave Market. Cambridge: Harvard University Press, 1999.

---., ed. The Chattel Principle: Internal Slave Trade the Americas. New Haven: Yale University Press, 2004.

Kelley, Robin D. G. Hammer and Hoe: Alabama Communists During the Great Depression. Chapel Hill: University of North Carolina Press, 1990.

Lerner, Gerda. The Creation of Patriarchy. New York: Oxford University Press, 1986.

Litwack, Leon F. North of Slavery: The Negro in the Free States, 1790-1860. Chicago: University of Chicago Press, 1961.

Marx, Anthony. Making Race and Nation: a comparison of South Africa, the United States, and Brazil. New York: Cambridge University Press, 1998.

McLaurin, Melton A. Celia, A Slave: A True Story. New York: Avon Books, 1991.

McNair, Glenn. Criminal Injustice: Slaves and Free Blacks in Georgia's Criminal Justice System. Charlottesville: University of Virginia Press, 2009.

Morgan, Jennifer L. Laboring Women: Reproduction and Gender in New World Slavery. Philadelphia: University of Pennsylvania Press, 2004.

Morris, Thomas D. Southern Slavery and the Law, 1619-1860. Chapel Hill: University of North Carolina Press, 1996.

Morrison, Toni, ed. Race-ing Justice En-gendering Power: Essays on Anita Hill, Clarence Thomas, and the Construction of Social Reality. New York: Pantheon Books, 1992.

Moses, Wilson Jeremiah. The Golden Age of Black Nationalism, 1850-1925. New York: Oxford University Press, 1978.

Muhammad, Khalil Gibran. The Condemnation of Blackness: Race, Crime, and the Making of Modern Urban America. Cambridge: Harvard University Press, 2011.

Nelson, Jr., William E. Black Atlantic Politics: Dilemmas of Political Empowerment in Boston and Liverpool. Albany : State University of New York Press, 2000. 
Painter, Nell Irvin. Southern History Across the Color Line. Chapel Hill: The University of North Carolina Press, 2002.

---. The Narrative of Hosea Hudson: The Life and Times of a Black Radical. New York: W. W. Norton \& Co., 1979.

Peabody, Sue and Keila Grinberg, eds. Slavery, Freedom, and the Law in the Atlantic World: A Brief History With Documents. Boston: Bedford, St. Martin, 2007.

Peiss, Kathy, ed. Major Problems in the History of American Sexuality. New York: Houghton Mifflin Co., 2002.

Pierson, Gerald J. The Nature of Resistance in South Carolina's Works Progress Administration Ex-Slave Narratives. Toledo: Dissertation.com Publishers, 1990.

Pincus, Samuel N. The Virginia Supreme Court, Blacks and the Law, 1870-1902. New York: Garland Publishing, Inc., 1990.

Powers, Willow Roberts. Transcription Techniques for the Spoken Word. New York: AltaMira Press, 2005.

Raegan, Leslie L. When Abortion Was a Crime: Women, Medicine, and Law in the United States, 1867-1973. Berkeley: University of California Press, 1997.

Regosin, Elizabeth. Freedom's Promise: Ex-Slave Families and Citizenship in the Age of Emancipation. Charlottesville: University Press of Virginia, 2002.

Roberts, Dorothy. Killing the Black Body: Race, Reproduction, and the Meaning of Liberty. New York: Pantheon Books, 1997.

Robinson, Cedric. Black Marxism: the Making of the Black Radical Tradition. Chapel Hill, N.C.: University of North Carolina Press, 2000

Rucker, Walter Clifford. “'The River Floweth On': The African Social and Cultural Origins of Slave Resistance in North America, 1712- 1831." Ph.D. Diss., University of California, 1999.

Schechter, Patricia. Ida B. Wells-Barnett \& American Reform: 1880-1930. Chapel Hill: University of South Carolina Press, 2001.

Schwartz, Marie Jenkins. Born in Bondage: Growing Up Enslaved in the Antebellum South. Cambridge: Harvard University Press, 2000.

Schwarz, Philip J. Slave Laws in Virginia. Athens: University of Georgia Press, 1996. 
Sharpley-Whiting, T. Denean. Black Venus: Sexualized Savages, Primal Fears, and Primitive Narratives in French. Durham, N.C.: Duke University Press, 1999.

Sklar, Kathryn Kish and Thomas Dublin, eds. Women and Power in American History: A Reader, Vol. 1 to 1880. Englewood Cliffs: Prentice Hall, Inc., 1991.

Smithers, Gregory D. Slave Breeding: Sex, Violence, \& Memory in African American History. Gainesville: University Press of Florida, 2012.

Sommerville, Diane Miller. Rape and Race in the Nineteenth-Century South. Chapel Hill: University of North Carolina Press, 2004.

Stampp, Kenneth. The Peculiar Institution: Slavery in the Antebellum South. New York: Knopf, 1956.

Stoler, Ann Laura, ed. Haunted By Empire: Geographies of Intimacy in North American History. Durham: Duke University Press, 2006.

---. Race and the Education of Desire: Foucault's History of Sexuality and the Colonial Order of Things. Durham: Duke University Press, 1995.

Swarns, Rachel L. American Tapestry: The Story of Black, White, and Multiracial Ancestors of Michelle Obama. New York: Harper Collins Publishers, 2012.

Tushnet, Mark V. The American Law of Slavery, 1810-1860: Considerations of Humanity and Interest. Princeton: Princeton University Press, 1981.

---. Slave Law in the American South: State v. Mann in History and Literature. Lawrence: University Press of Kansas, 2003.

Tyson, Timothy B. Radio Free Dixie: Robert F. Williams and the Roots of Black Power. Chapel Hill : University of North Carolina Press, 1999.

Urofsky, Melvin I. and Paul Finkelman, Documents of American Constitutional and Legal History: From the Founding Through the Age of Industrialization (Vol. 1, Second Edition). New York: Oxford University Press, 2002.

Vaz, Kim Marie. Oral Narrative Research with Black Women. Thousand Oaks: Sage Publications, 1997.

Weisenburger, Steven. Modern Medea: A Family Story of Slavery and Child-Murder from the Old South. New York: Hill and Wang, 1998.

West, Cornel and Eddie S. Glaude, Jr., eds. African American Religious Thought: An 
Anthology. Louisville: Westminster John Knox Press, 2003.

White, Deborah Gray. Ar'n't I a Woman?: Female Slaves in the Plantation South. New York: W. W. Norton \& Company, Inc., 1985.

---. Too Heavy a Load: Black Women in Defense of Themselves, 18941994. New York: W. W. Norton \& Company, Inc., 1999.

Willis, Deborah and Carla Williams. The Black Female Body: A Photographic History. Philadelphia: Temple University Press, 2002.

---. Black Venus, 2010: They Called Her "Hottentot." Philadelphia: Temple University Press, 2010.

Yellin, Jean Fagan and John C. Van Horne, eds. The Abolitionist Sisterhood: Women's Political Culture in Antebellum America. Ithaca : Cornell University Press, 1994.

Yow, Valerie Raleigh. Recording Oral History: A Guide for the Humanities and Social Sciences. New York: AltaMira Press, 2005.

Secondary Sources (Articles and Chapters):

Abdur-Rahman, Aliyyah I. "'The Strangest Freaks of Despotism": Queer Sexuality in Antebellum African American Slave Narratives." African American Review (June 22, 2006) www.thefreelibrary.com.

Accomando, Christina. "'The Laws were Laid Down to Me Anew": Harriet Jacobs and the Reframing of Legal Fictions." African American Review, Vol. 32, No. 2 (Summer 1998): 229-245. www.jstor.org.

Angelou, Maya. "They Came to Stay." In I Dream a World: Portraits of Black Women Who Changed America, edited by Brian Lanker. New York: Stewart, Tabori, and Chang, 1989.

Bardaglio, Peter W. "Rape and the Law in the Old South: Calculated to Excite Indignation in Every Heart." The Journal of Southern History, Vol. 60, No. 4 (November 1994): 749-772.

Bauer, Raymond A. and Alice H. Bauer. "Day to Day Resistance to Slavery." The Journal of Negro History, Vol. 7, No. 4 (October 1942): 388-419. www.jstor.org.

Blassingame, John W. "Using the Testimony of Ex-Slaves: Approaches and Problems." The Journal of Southern History, Vol. 41, No. 4 (November 1975): 473-482. www.jstor.org. 
Block, Mary R. "Rape Law in 19th-Century America: Some Thoughts and Reflections on the State of the Field." History Compass, (July 2009): 1391-1399.

Block, Sharon. "Lines of Color, Sex, and Service: Comparative Sexual Coercion in Early America." In Sex, Love, Race: Crossing Boundaries in North American History, edited by Martha Hodes. New York: New York University Press, 1999.

Briggs, Laura. "The Race of Hysteria: "Overcivilization" and the "Savage" Woman in Late Nineteenth-Century Obstetrics and Gynecology." American Quarterly, Vol. 52, No. 2 (2000): 246-273.

Camp, Stephanie M. H. "The Pleasures of Resistance: Enslaved Women and Body Politics in the Plantation South, 1830-1861. The Journal of Southern History, Vol. 68, No. 3 (Aug. 2002): 533-572.

Cardyn, Lisa. "Sexual Terror in the Reconstruction South." In Battle Scars: Gender and Sexuality in the American Civil War, edited by Catherine Clinton and Nina Silber. Oxford: University Press, 2006.

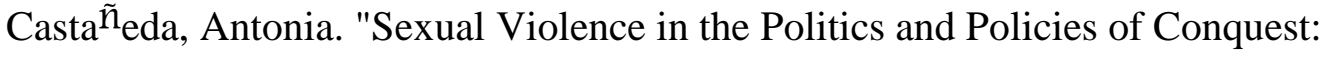
Amerindian Women and the Spanish Conquest of Alta California. In Building With Our Hands: New Directions in Chicana Studies, edited by Adela de la Torre and Beatríz M. Pesquera. Berkeley: University of California Press, 1993. http://annasampaio.com/uploads/AntoniaCastaneda.pdf

Colin, Palmer A. "Slave Resistance." Reviews in American History, Vol. 26, No. 2 (1998): 371-374. http://muse.jhu.edu/journals/reviews_in_american_history/v026/26.2palmer.html.

Cott, Nancy F. "Marriage and Women's Citizenship in the United States, 1830-1934." The American Historical Review, Vol. 103, No. 5 (Dec. 1998): 1440-1474. www.jstor.org.

Cullen-DuPont, Kathryn. "State of Missouri v. Celia, a Slave: 1855." Great American Trials (2002). http://www.encyclopedia.com/doc/1G2-3498200071.html.

Curtis, Mary C. The Washington Post, "Why Michelle Obama's Very American Story Still Causes a Stir," July 12, 2012. http://www.washingtonpost.com/blogs/she-thepeople/post/why-michelle-obamas-very-american-story-still-causes-astir/2012/07/12/gJQA6Vn9eW_blog.html.

Duvivier, Sandra C. "Freedom, Bodily Trauma, and Survival: New Trajectories in African American Women's Literary Criticism." Journal of African American History, Vol. 97, No. 3 (Summer 2012): 303-311. 
Edwards, Laura F. "Status Without Rights: African Americans and the Tangles History of Law and Governance in the Nineteenth-Century U.S. South." The American Historical Review, Vol. 112, No. 2 (April 2007): 365-393.

Flanigan, Daniel J. "Criminal Procedure in Slave Trials in the Antebellum South." The Journal of Southern History, Vol. 20, No. 4 (November 1974): 537-564.

Greene, Sally. "State V. Mann Exhumed." North Carolina Law Review, Vol. 87, No. 3 (March 2009): 701-755.

Hasday, Jill Elaine. "Contest and Consent: A Legal History of Marital Rape." California Law Review, Vol. 88, No. 5 (October 2000): 1373-1506.

Higginbotham, Jr., A. Leon and Barbara K. Kopytoff. "Racial Purity and Interracial Sex in the Law of Colonial and Antebellum Virginia." Georgetown Law Journal, Vol. 77 (August 1989): 1967-2028. www.lexis-nexis.com.

Higginbotham, Jr., A. Leon. "Racism and the Early American Legal Process, 16191896." Annals of the American Academy of Political and Social Science, Vol. 407, Blacks and the Law (May 1973): 1-17. www.jstor.org.

Hine, Darlene Clark. "Black Professionals and Race Consciousness: Origins of the Civil Rights Movement, 1890-1950." The Journal of American History, Vol. 89, No. 4 (March 2003): 1279-1294.

---. "Rape and the Inner Lives of Black Women in the Middle West." Signs, Vol. 14, No. 4 (Summer 1989): 912-920.

Johnson, Michael P. "Smothered Slave Infants: Were Slave Mothers at Fault?" The Journal of Southern History, Vol. 47, No. 4 (November 1981): 493-520. www.jstor.org.

Johnson, Walter. "The Pedestal and the Veil: Rethinking the Capitalism/Slavery Question." Journal of the Early Republic, Vol. 24, No. 2 (Summer 2004): 299308.

Kay, Tamara and Nicola Beisel. "Abortion, Race, and Gender in Nineteenth-Century America." American Sociological Review, Vol. 69, No. 4 (2004): 498-518.

King, Wilma. "Suffer with Them Till Death: Slave Women and Their Children in Nineteenth-Century America." In More Than Chattel: Black Women and Slavery in the Americas, edited by David Barry Gaspar and Darlene Clark Hine. Bloomington: Indiana University Press, 1996. 
Landers, Jane. "'In Consideration of Her Enormous Crime": Rape and Infanticide in Spanish St. Augustine." In The Devil's Lane: Sex and Race in the Early South, edited by Catherine Clinton and Michele Gillespie. New York: Oxford University Press, 1997: 205-214.

McWhirter, Cameron. “A Remnant of Slavery’s Horror.” Cincinnati Enquirer (October 2, 1998). www.enquirer.com.

Nicolaisen, Peter. "Thomas Jefferson, Sally Hemings, and the Question of Race: An Ongoing Debate." Journal of American Studies, Vol. 37, No. 1 (2003): 99-118.

Painter, Nell Irvin. "Hill, Thomas, and the Use of Racial Stereotype," in Race-ing Justice En-gendering Power: Essays on Anita Hill, Clarence Thomas, and the Construction of Social Reality, edited by Toni Morrison (New York: Pantheon Books, 1992): 200-214.

Painter, Nell Irvin. "Representing Truth: Sojourner Truth's Knowing and Becoming Known." Journal of American History, Vol. 81, No. 2 (September 1994): 461492.

Pascoe, Peggy. "Race, Gender, and Intercultural Relations: The Case of Interracial Marriage." Frontiers: A Journal of Women Studies, Vol. 12, No. 1 (1991): 5-18. www.jstor.org.

Peabody, Sue. "Microhistory, Biography, Fiction: The Politics of Narrating the Lives of People Under Slavery." Transatlantica, (2012/2). http://transatlantica.revues.org/6184.

Reinhardt, Mark. "Who Speaks for Margaret Garner? Slavery Silence, and the Politics of Ventriloquism." Critical Inquiry, Vol. 29 (2002): 81-119. www.journals.uchicago.edu.

Shaw, Stephanie J. "Using the WPA Slave Narratives to Study the Impact of the Great Depression." The Journal of Southern History, Vol. 69, No. 3 (August 2003): 623-658.

Sitomer, Joan. "Is a Slave 'Any Woman'? Slavery, Sex, and Claims of Citizenship in State of Missouri v. Celia, a Slave." Paper presented at the annual meeting of the Midwest Political Science Association, Chicago, IL, Apr 12, 2007. http://citation.allacademic.com/meta/p198068_index.html

Spindel, Donna J. “Assessing Memory: Twentieth-Century Slave Narratives Reconsidered.” Journal of Interdisciplinary History, Vol. 27, No. 2 (Autumn 1996): 247-261. www.jstor.org. 
Steckel, Richard H. "Women, Work, and Health under Plantation Slavery in the United States." In More Than Chattel: Black Women and Slavery in the Americas, edited by David Barry Gaspar and Darlene Clark Hine. Bloomington: Indiana University Press, 1996.

Stetson, Erlene. "Studying Slavery: Some Literary and Pedagogical Considerations on the Black Female Slave." In All the Women Are White, All the Blacks Are Men, But Some of Us Are Brave: Black Women's Studies, edited by Gloria T. Hull, Patricia Bell Scott, and Barbara Smith. New York: The Feminist Press, 1982.

Stevenson, Brenda E. "Women, Slavery, and the Atlantic World." The Journal of African American History, Vol. 98, No. 1, (Winter 2013): 1-6. www.jstor.org.

Stone, Andrea. "Interracial Sexual Abuse and Legal Subjectivity in Antebellum Law and Literature." American Literature, Vol. 81, No. 1 (March 2009): 65-92.

VanderVelde, Lea and Sandhya Subramanian. "Mrs. Dred Scott." The Yale Law Journal Vol. 106, No. 4 (January 1997): 1033-1122. www.jstor.org.

Wright, George C. "Oral History and the Search for the Black Past in Kentucky." Oral History Review, Vol. 10 (1982): 73-91. www.jstor.org.

Yanuck, Julius. "The Garner Fugitive Slave Case." The Mississippi Valley Historical Review, Vol. 40, No. 1 (June 1953): 47-66. www.jstor.org.

Yetman, Norman R. "Ex-Slave Interviews and the Historiography of Slavery." American Quarterly, Vol. 36, No. 2 (Summer 1984): 181-210. www.jstor.org.

---. "The Background of the Slave Narrative Collection." American Quarterly, Vol. 19, No. 3 (Autumn 1967): 534-553. 